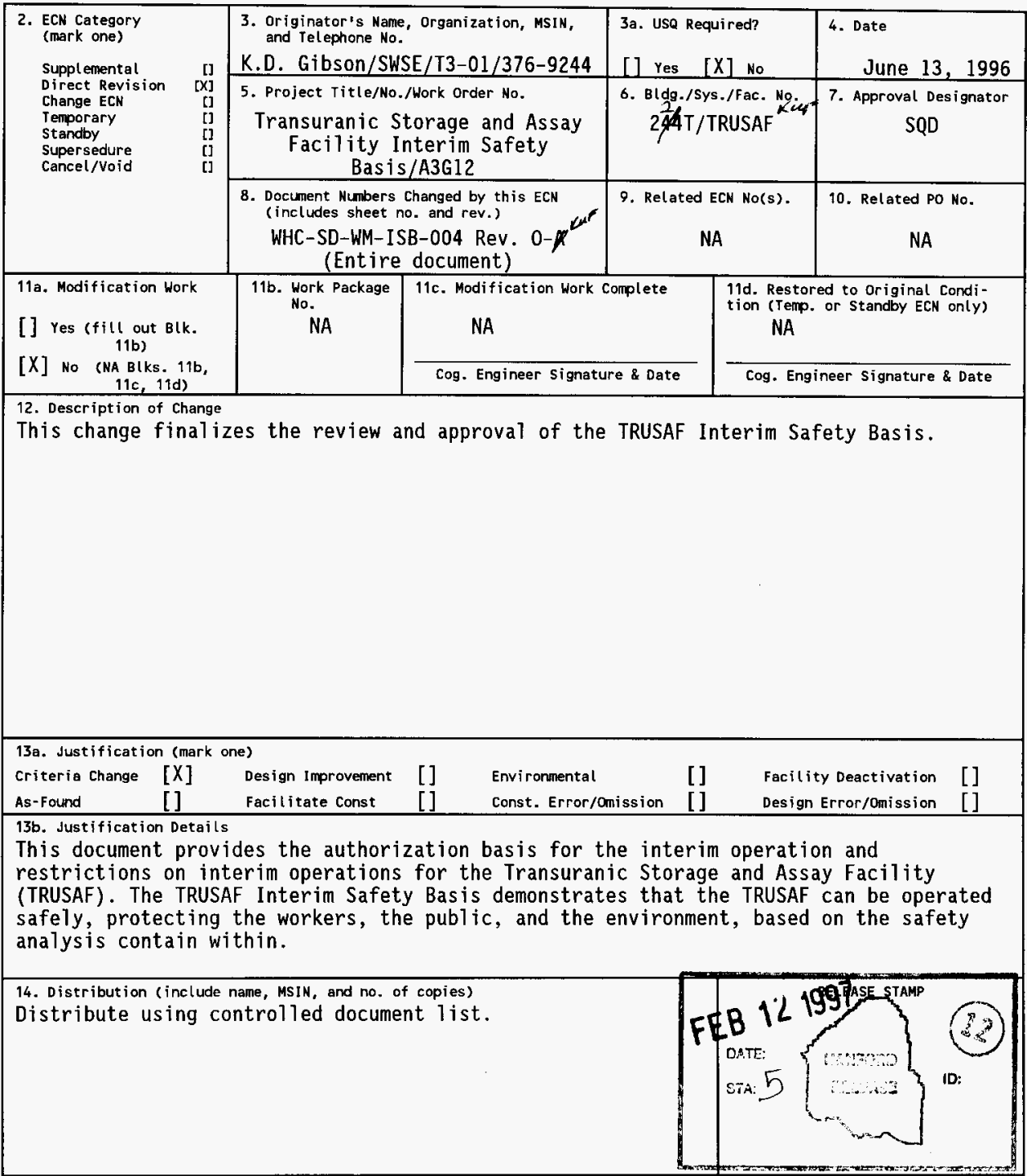




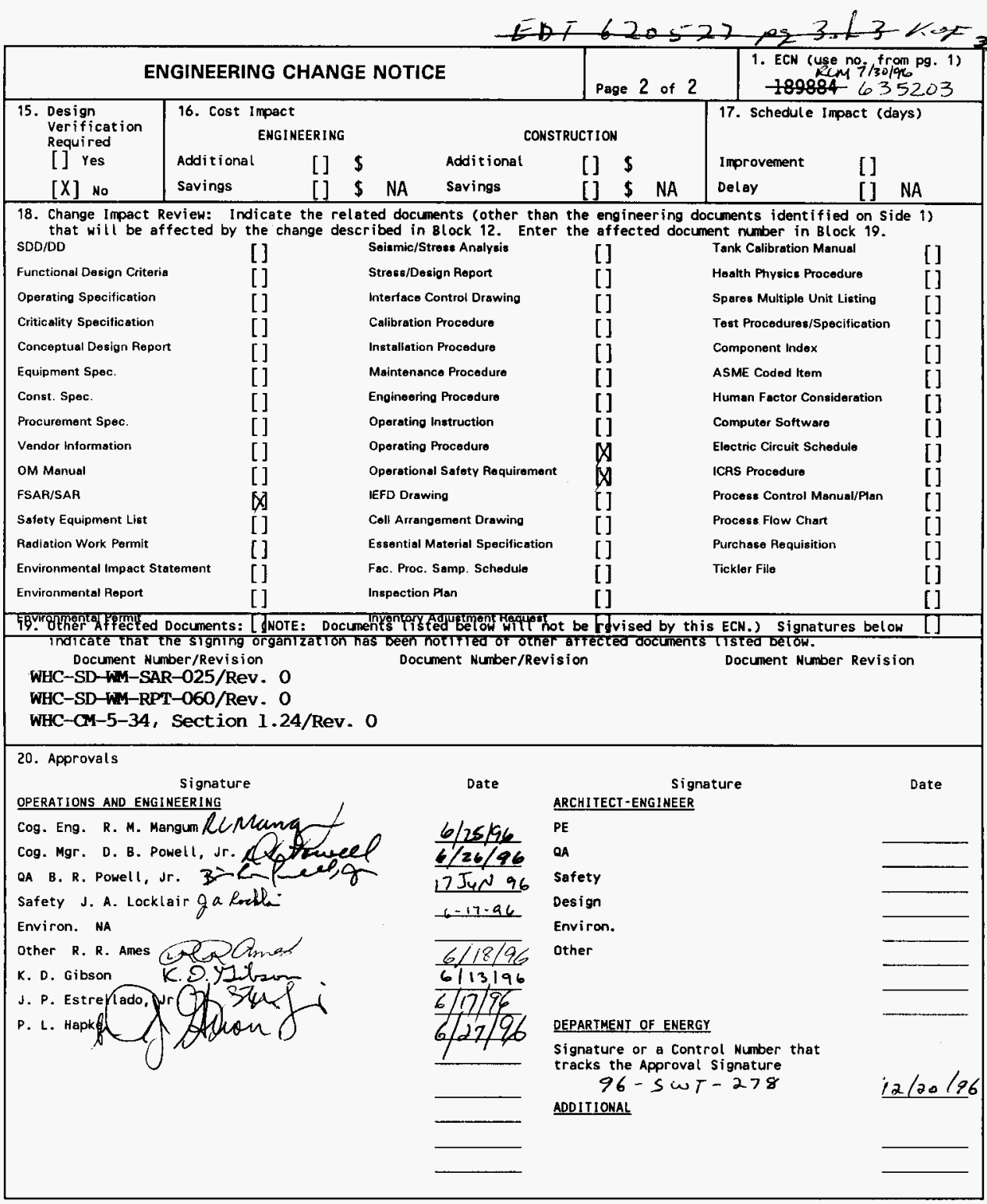




\title{
TRANSURANIC STORAGE AND ASSAY FACILITY INTERIM SAFETY BASIS
}

\author{
B. H. Gilbert/D. R. Porten/K. D. Gibson
}

Westinghouse Hanford Company, Richland, WA 99352

U.S. Department of Energy Contract DE-AC06-87RL 10930

$\begin{array}{llll}\text { EDT } / \text { ECN: } & 635203 & \text { UC: } 2020 & \\ \text { Org Code: } & 8 M 300 & \text { Charge Code: } & \text { A3G12 } \\ \text { B\&R Code: } & \text { EW3130020 } & \text { Total Pages: } & 152\end{array}$

Key Words: Interim Safety Basis, Initial Hazard Category 2

Abstract: The Transuranic Waste Storage and Assay Facility (TRUSAF) Interim Safety Basis document provides the authorization bas is for the interim operation and restriction on interim operations for the TRUSAF. The TRUSAF ISB demonstrates that the TRUSAF can be operated safely, protecting the workers, the public, and the environment. The previous safety analysis document TRUSAF Hazards Identification and Evaluation (WHC 1987) is superseded by this document.

TRADEMARK DISCLAIMER. Reference herein to any specific commercial product, process, or service by trade name, trademark, manufacturer, or otherwise, does not necessarily constitute or imply its endorsement, recommendation, or favoring by the United States Government or any agency thereof or its contractors or subcontractors.

Printed in the United States of America. To obtain copies of this document, contact: WHC/BCS Document Control Services, P.O. Box 1970, Mailstop H6-08, Richland WA 99352, Phone (509) 372-2420; Fax (509) 376-4989.
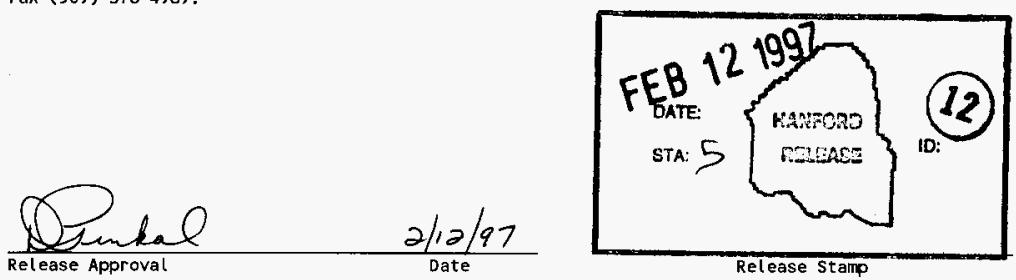

\section{Approved for Public Release}




\section{RECORD OF REVISION}

(1) Document Number

WHC-SD-WM-ISB004 , Rev 1

(2) Title

Transuranic Storage and Assay Facility Interim Safety Basis

CHANGE CONTROL RECORD

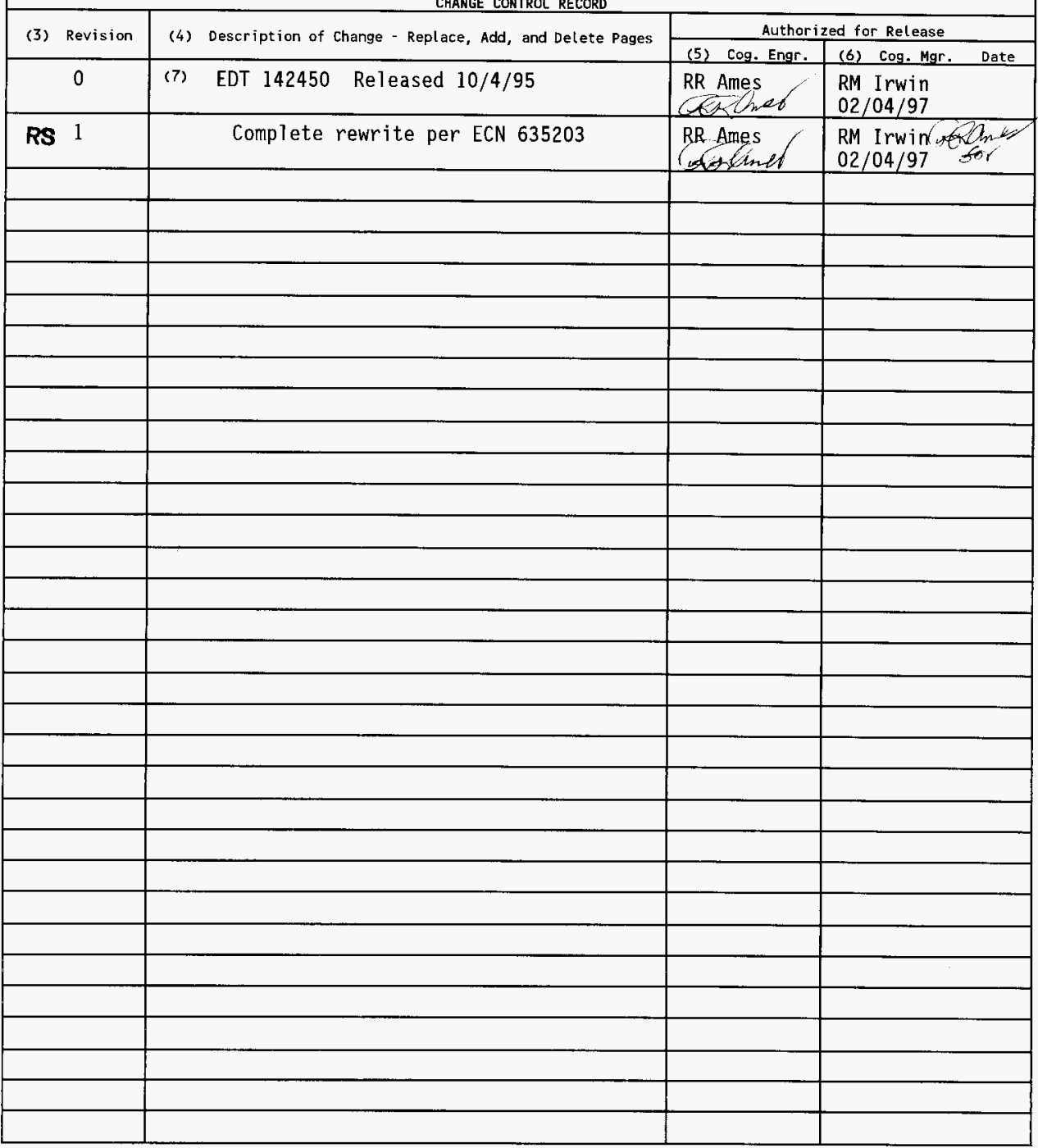




\section{TRANSURANIC WASTE STORAGE AND ASSAY \\ FACILITY INTERIM SAFETY BASIS \\ Revision 1}

WHC-SD-WM-ISB-004

January 1997 
WHC-SD-WM-ISB-004 REV 1

This page intentionally left blank. 


\section{CONTENTS}

1.0 INTRODUCTION AND SUMMARY ................ 1-1

1.1 BACKGROUND . . . . . . . . . . . . . . . . 1-1

1.2 INTRODUCTION . . . . . . . . . . . . . . . . . . . 1-1

1.3 CONFIGURATION MANAGEMENT SUMMARY . . . . . . . . . . . 1-2

1.4 SAFETY ANALYSIS SUMMARY . . . . . . . . . . . . . . . . . $1-2$

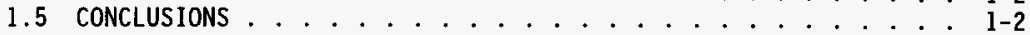

2.0 FACILITY DESCRIPTION . . . . . . . . . . . . . . 2-1

2.1 FACILITY OVERVIEW . . . . . . . . . . . . . . 2-1

2.2 FACILITY STRUCTURE $\ldots \ldots \ldots \ldots$

2.3 EQUTPMENT . . . . . . . . . . . . . . . . . . . . 2-9

2.4 CONFINEMENT SYSTEMS . . . . . . . . . . . . . . . . . . 2-10

2.5 SAFETY SUPPORT SYSTEMS ............... . . 2-11

2.5.1 Fire Protection ................ 2-11

2.5.2 Air Sampling/Monitoring . . . . . . . . . . . 2-12

2.5.3 Safety Communications and Controls . . . . . . . 2-12

2.6 UTILITY DISTRIBUTION SYSTEMS . . . . . . . . . . . . . . . . 2 2-13

2.7 PROCESS DESCRIPTION . . . . . . . . . . . . . . . . 2 2-13

2.7.1 Retrieved Waste . . . . . . . . . . . . 2-16

2.7.2 Newly Generated Waste . . . . . . . . . . 2-16

3.0 INTERIM SAFETY BASIS EVALUATION ............. . . . . . .

3.1 HAZARD ANALYSIS ................... . . . . . . .

3.1.1 Hazard Categorization . . . . . . . . . . 3-1

3.1.2 Hazards Analysis Affect on Hazard Categorization . . . 3-2

3.1.3 Preliminary Hazards Analysis ............ 3-2

3.1 .4 Accident Analysis . . . . . . . . . . . 3-12

3.1.5 Basis for Inventory Control . . . . . . . . . 3-38

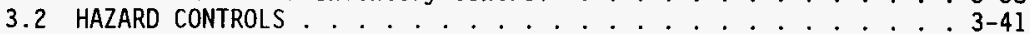

3.2.1 Safety Systems, Structures, and Components . . . 3-41

3.2.2 Administrative Controls/Operational Restrictions . . . 3-41

3.2.3 Institutional Safety Programs . . . . . . . . . 3-43

3.3 SUMMARY . . . . . . . . . . . . . . . . . . . . . 3-44

4.0 CONFIGURATION CONTROLS SYSTEM ................. . . . . . .

4.1 CONFIGURATION CONTROL PROCEDURES . . . . . . . . . . . . . 4-1

4.2 UNREVIEWED SAFETY QUESTION PROCEDURES . . . . . . . . . . $4-1$

4.3 QUALITY ASSURANCE PROCEDURES . . . . . . . . . . . . . 4-1

5.0 REFERENCES . . . . . . . . . . . . . . . . 5-1

5.1 DOCUMENTS . . . . . . . . . . . . . . . . . . . 5-1

5.2 U.S. DEPARTMENT OF ENERGY ORDERS .............. $5-4$

5.3 CONTROLLED MANUALS . . . . . . . . . . . . . . . . . 5-5 


\section{APPENDIXES}

A RADIOLOGICAL CHARACTERIZATION ............... A-1

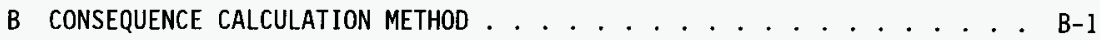

c COMBUSTIBLE ChARACTERIZATION ................... c-1

D PROCESS CELLS DESCRIPTION ................ . . D-1

E SAFETY EVALUATION REPORT ................. E-1 


\section{LIST OF FIGURES}

2-1 The Hanford Site. . . . . . . . . . . . . . 2-2

2-2 The 200 West Area. . . . . . . . . . . . . . . . 2-3

2-3 The Heating, Ventilating, and Air Conditioning System for the 224-T Building .................. 2-. . . . . .

2-4 Floor Plan of the 224-T Building ............. 2-5

2-5 Cross Section of the 224-T Building. . . . . . . . . . 2-6

2-6 Transuranic Waste Storage and Assay Facility Process Flow (Ground Floor) ................... . 2-14

3-1 Four-by-Four Probability and Consequence-Ranking Matrix . . . . . . 3-9

3-2 $\mathrm{CCl}_{4}$ Carbon Tetrachloride Risk Comparison Guidelines . . . . . . . . 3-35

3-3 $\mathrm{COCl}_{2}$ Phosgene Risk Comparison Guidelines . . . . . . . . . 3-36 


\section{LIST OF TABLES}

1-1 Accident Analysis Summary .................. 1-3

3-1 Transuranic Waste Storage and Assay Facility Hazard Analysis . . . 3-4

3-2 Qualitative Accident Severity Levels . . . . . . . . . . . . . . 3-10

3-3 Frequency Ranges. . . . . . . . . . . . . . . . . 3-10

3-4 Process and Equipment Limits ................ 3-11

3-5 Storage Array Limits . . . . . . . . . . . . . . . . . . 3-11

3-6 Storage Array Limits for Assayed Drums $>200 \mathrm{~g}$. . . . . . . . . . . 3-11

3-7 Nomina $12 \%{ }^{240} \mathrm{Pu}$, Aged Twenty Years ... . . . . . . . . . . 3-12

3-8 Hazardous Characteristics for Drums at Transuranic Waste Storage and Assay Facility ............. . . 3-13

3-9 Dose Consequences of Fork lift Accident without High-Efficiency Particulate Air Filtration . . . . . . . . . . . 3-16

3-10 Forklift Accident Comparison . . . . . . . . . . 3-17

3-11 Dose Consequences of Drum Fire without High-Efficiency Particulate Air Filtration . . . . . . . . . . . . . . . 3-20

3-12 Drum Fire Comparison . . . . . . . . . . . . . . 3-22

3-13 Dose Consequences of Drum Explosion without High-Efficiency Particulate Air Filtration . . . . . . . . . . . . 3-25

3-14 Drum Explosion Comparison . . . . . . . . . . . 3-26

3-15 Seismic Design Criteria . . . . . . . . . . . . 3-27

3-16 Dose Consequences of Seismic Event ........... . 3-30

3-17 Seismic Event Comparison . . . . . . . . . . . . . . 3-31

3-18 Significant Hazardous Materials at the Transuranic Waste Storage and Assay Facility . . . . . . . . . . . . . . 3-32

3-19 Carbon Tetrachloride Concentrations . . . . . . . . . 3-33

3-20 Phosgene $\left(\mathrm{COCl}_{2}\right)$ Gas Concentrations . . . . . . . . . . 3-33

3-21 Hazardous Materials in Retrieved Drums . . . . . . . . . 3-37 


\section{LIST OF TERMS}

$\begin{array}{ll}\text { ARF } & \text { airborne release fraction } \\ \text { CAM } & \text { continuous air monitor } \\ \text { CWC } & \text { Central Waste Complex } \\ \text { DOE } & \text { U.S. Department of Energy } \\ \text { DOT } & \text { U.S. Department of Transportation } \\ \text { EDE } & \text { effective dose equivalent } \\ \text { HEPA } & \text { high-efficiency particulate air (filter) } \\ \text { ISA } & \text { interim safety analysis } \\ \text { ISB } & \text { interim safety basis } \\ \text { LLW } & \text { low-level waste } \\ \text { LLMW } & \text { low-level mixed waste } \\ \text { MFP } & \text { mixed fission products } \\ \text { PE-Ci } & \text { plutonium equivalent curies } \\ \text { RF } & \text { respirable fractions } \\ \text { RL } & \text { DOE, Richland Operations office } \\ \text { RTR } & \text { real-time radiography } \\ \text { SSC } & \text { safety class systems, structures, and components } \\ \text { SWBG } & \text { solid waste burial grounds } \\ \text { TRU } & \text { transuranic (waste) } \\ \text { TRUSAF } & \text { Transuranic Waste Storage and Assay Facility } \\ \text { TSR } & \text { technical safety requirement } \\ \text { USQ } & \text { unreviewed safety question } \\ \text { WHC } & \text { Westinghouse Hanford Company } \\ \text { WIPP } & \text { Waste Isolation Pilot Plant (Carlsbad, NM) } \\ \text { WRAP } & \text { Waste Receiving and Processing (Facility) } \\ \text { WRAP 1 } & \text { Waste Receiving and Processing Facility Module 1 }\end{array}$


WHC-SD-WM-ISB-004 REV 1

This page intentionally left blank. 


\subsection{INTRODUCTION AND SUMMARY}

This document has been approved by $D 0 E$ as shown in Appendix E, Safety Evaluation Report.

This document (ISB-004) provides the interim safety basis (ISB) for the operation of the Transuranic Waste Storage and Assay Facility (TRUSAF). The previous safety analysis document, TRUSAF Hazards Identification and Evaluation, WHC-SD-WM-SAR-025, Rev. O (WHC 1987), is superseded by this document. This ISB will be canceled once the U.S. Department of Energy (DOE) approves the facility safety analysis report and the technical safety requirements (TSRs), which will have been upgraded, in accordance with the DOE Order 5480.21, Unreviewed Safety Questions; DOE Order 5480.22, Technical Safety Requirements; and DOE Order 5480.23, Nuclear Safety Analysis Reports.

\subsection{BACKGROUND}

The Hanford Site covers $\approx 1,450 \mathrm{~km}^{2}$ (560 $\mathrm{mi}^{2}$ ) of semi-arid land owned by the U.S. Government and managed by DOE. The U.S. Army Corps of Engineers selected the Hanford Site in early 1943 as the location for reactors, chemical separation, and related facilities and activities for production and purification of plutonium. Radioactive wastes were a by-product of these activities. When efforts to dispose of these wastes began in 1944, all solid wastes were placed in trenches and covered with earth to prevent release of contamination. Since May 1970, however, DOE has required that radioactive wastes be categorized as either transuranic (TRU) waste and placed in retrievable storage or non-TRU waste and placed in nonretrievable disposal sites.

\subsection{INTRODUCTION}

TRUSAF provides a central Tocation for interim storage of newly generated and retrieved TRU waste. Administrative waste processing in TRUSAF includes (1) inspection of containers (exterior only) and associated documentation, (2) examination with a real-time radiography (RTR) system to confirm the absence of prohibited items, and (3) neutron assay of the waste containers to confirm fissile isotope content. A data package placed with each container indicates their progress through the administrative process. The data packages are filed and the containers are placed in assigned storage modules in rows following a marked pattern on the floor. TRUSAF is initially designated as a Hazard Category 2 facility based on the methodology in DOE-STD-1027-92, Hazard Categorization and Accident Analysis Techniques for Compliance with DOE Order 5480.23, Nuclear Safety Analysis Reports. Following completion of the hazard analysis in this report, it was concluded that the operation of the TRUSAF is consistent with the criteria of DOE-STD-1027-92, to define the facility as having a potential for only significant localized consequences. Hence, any DOE Orders or Standards that reference hazard categorization for purposes other than safety analysis report (SAR) 
preparation will be based on the hazard analys is conclusion that TRUSAF operations have a potential for only significant localized consequences. TRUSAF is classified as a limited control facility, in accordance with WHC-CM-5-36, Chapter 4-29, "Nuclear Criticality Safety Manual."

\subsection{CONFIGURATION MANAGEMENT SUMMARY}

ISB-004 is based upon current facility configuration and procedures. Changes to the facility configuration or procedures could impact both the authorization and safety bases. A configuration management program is necessary to evaluate the impact of such changes. The unreviewed safety question (USQ) program is part of this configuration management program. The USQ program ensures that all changes to the facility and associated procedures are reviewed by trained USQ evaluators. Engineering practices provide uniform methods for design review, configuration control, change control, engineering documentation preparation, and review/approval requirements. Document control procedures also provide a consistent method for initiating new procedures and making changes to existing procedures. These programs ensure that the facility physical configuration conforms with reviewed and approved design and safety analysis requirements, and are reflected accurately in facility documentation.

\subsection{SAFETY ANALYSIS SUMMARY}

A preliminary hazard analysis was performed in Section 3.1 .2 to identify and qualitatively evaluate potential hazards at TRUSAF. The following subset of potential accidents was selected from the preliminary hazard analysis for quantitative analysis, based on both frequency and consequence considerations:

- Forklift accident

- Drum fire

- Drum explosion

- Seismic event

- Vehicle fire (toxicological).

Table 1-1 summarizes the results of the accident analyses. To conservatively determine the risks associated with the storage of drums at TRUSAF, the accident analysis assumes a maximum TRU drum 1 oading of $400 \mathrm{~g} \mathrm{Pu}$, even though Hanford Site Solid Waste Acceptance Criteria, WHC-EP-0063 (Willis 1994), limits drums to $\leq 200 \mathrm{~g}$ of fissile material. The risks from analyzed TRUSAF operations are within the same risk guidelines accepted in the Solid Waste Burial Grounds Interim Safety Basis (ISB) (WHC 1995a).

The results reported for the drum fire and drum explosion scenarios in Table 1-1 are based on a single drum event (i.e., the fire does not propagate). A fire hazards analysis performed for TRUSAF documents testing completed in 1995, which verified that a drum fire does not propagate (WHC 1996a). 


\subsection{CONCLUSIONS}

TRUSAF is initially designated as a Hazard Category 2 facility based on the methodology in DOE-STD-1027-92. The frequency and consequences of the accidents analyzed are within the risk-acceptance guidelines, accepted in the solid waste burial grounds (SWBG) interim safety basis (ISB) (WHC 1995a). Because administrative control interim operational safety requirements, configuration control, and institutional safety programs have been established it is concluded that the risk of continued operation of TRUSAF is acceptable.

Table 1-1. Accident Analysis Summary.

\begin{tabular}{|l|c|c|c|}
\hline \multicolumn{1}{|c|}{ Accident scenario } & \multirow{2}{*}{$\begin{array}{c}\text { Frequency } \\
\text { (per year) }\end{array}$} & \multicolumn{2}{c|}{ Consequences (EDE rem) } \\
\cline { 3 - 4 } & $1-1.0 \mathrm{E}-01$ & $1.2 \mathrm{E}-02$ & Offsite \\
\hline Forklift accident & $1.0 \mathrm{E}-02-1.0 \mathrm{E}-04$ & 1.9 & $3.0 \mathrm{E}-04$ \\
\hline Drum fire & $1.0 \mathrm{E}-03-1.0 \mathrm{E}-05$ & 5.7 & $1.4 \mathrm{E}-01$ \\
\hline Drum explosion & $1.0 \mathrm{E}-03$ & 3.4 & $8.5 \mathrm{E}-02$ \\
\hline Seismic event & $2.0 \mathrm{E}-05$ & $5.2 \mathrm{E}-01$ (ppm) & 6.2 E-02 (ppm) \\
\hline Vehicle fire (toxicological) & &
\end{tabular}

$E D E$ = effective dose equivalent.

ppm = parts per million. 
WHC-SD-WM-ISB-004 REV I

This page intentionally left blank.

$1-4$ 


\subsection{FACILITY DESCRIPTION}

\subsection{FACILITY OVERVIEW}

TRUSAF is located in the 224-T Building in the 200-West Area of the Hanford Site (Figures 2-1 and 2-2). The 224-T Building was constructed in the early 1940 s as a chemical processing unit for purifying plutonium. The facility was idle for several years after new processes made it obsolete. It eventually was modified to meet requirements for storing plutonium-bearing scraps and liquids. The cells in the process areas have been sealed and isolated from the operating gallery and service areas, although the two areas share a common ventilation system (Figure 2-3). While all of the TRUSAF assay and storage activities are included with the cells as is, any activity to enter the cells is beyond the scope of this analysis. The operating and service areas have been stripped of all unnecessary control equipment, panel boards, and partitions to provide $\approx 1,070 \mathrm{~m}^{2}\left(11,500 \mathrm{ft}^{2}\right)$ of storage space on three floors.

TRUSAF began storing contact-handled (i.e., surface dose rate $<200 \mathrm{mr} / \mathrm{h}$ ) TRU and TRU-mixed waste from DOE offsite and onsite generators in 1985 . Receipt of onsite-generated waste will include drums generated by the Pilot Retrieval Project. This project will retrieve drums from different existing storage locations, and qualify them for transport to and examination in TRUSAF. Detailed information regarding the Pilot Retrieval Project is documented in Final Safety Analysis for Contact-Handled Transuranic Waste Drum In Situ Inspection and Vented Drum Retrieval, WHC-SD-WM-SAR-058, Rev. 0 (WHC 1994a). Final disposal of the TRU and TRU-mixed waste could be at the Waste Isolation Pilot Plant (WIPP) in Carlsbad, New Mexico or at another approved disposal site.

\subsection{FACILITY STRUCTURE}

The 224-T Building is $\approx 60 \mathrm{~m}(197 \mathrm{ft})$ long, $18.3 \mathrm{~m}(60 \mathrm{ft})$ wide, and $12.2 \mathrm{~m}(40 \mathrm{ft}) \mathrm{high}$ and has three floors that allow for $\approx 1070 \mathrm{~m}^{2}\left(11,500 \mathrm{ft}^{2}\right)$ of storage space. Figure $2-4$ is a floor plan of the three gallery levels and Figure 2-5 is a typical cross section. The walls, floors, and ceiling are constructed of reinforced concrete.

The three floors of the building used for TRUSAF storage are sealed from the southeast half of the building, which contains six radiologicallycontaminated process cells (A through $F$ ). Cells $A$ through $F$ are not and will not be considered as used for storage in this safety analysis. The accident analysis is designed to bound the potential consequences from the inventory in the sealed cells, but not any operation there. The outside doors to these cells were scheduled to be sealed. The sealing project was suspended to allow access to the cells for roof inspection. The outside door to cell $\mathrm{A}$ was sealed before the project was halted. The funding for this project has not been restored. Presently, air leakage through the doors provides the supply air to the process cells.

The three floors are connected by stairway $A$ at the north end of the building, stairway $B$ at the south end of the building, and an elevator 
Figure 2-1. The Hanford Site.

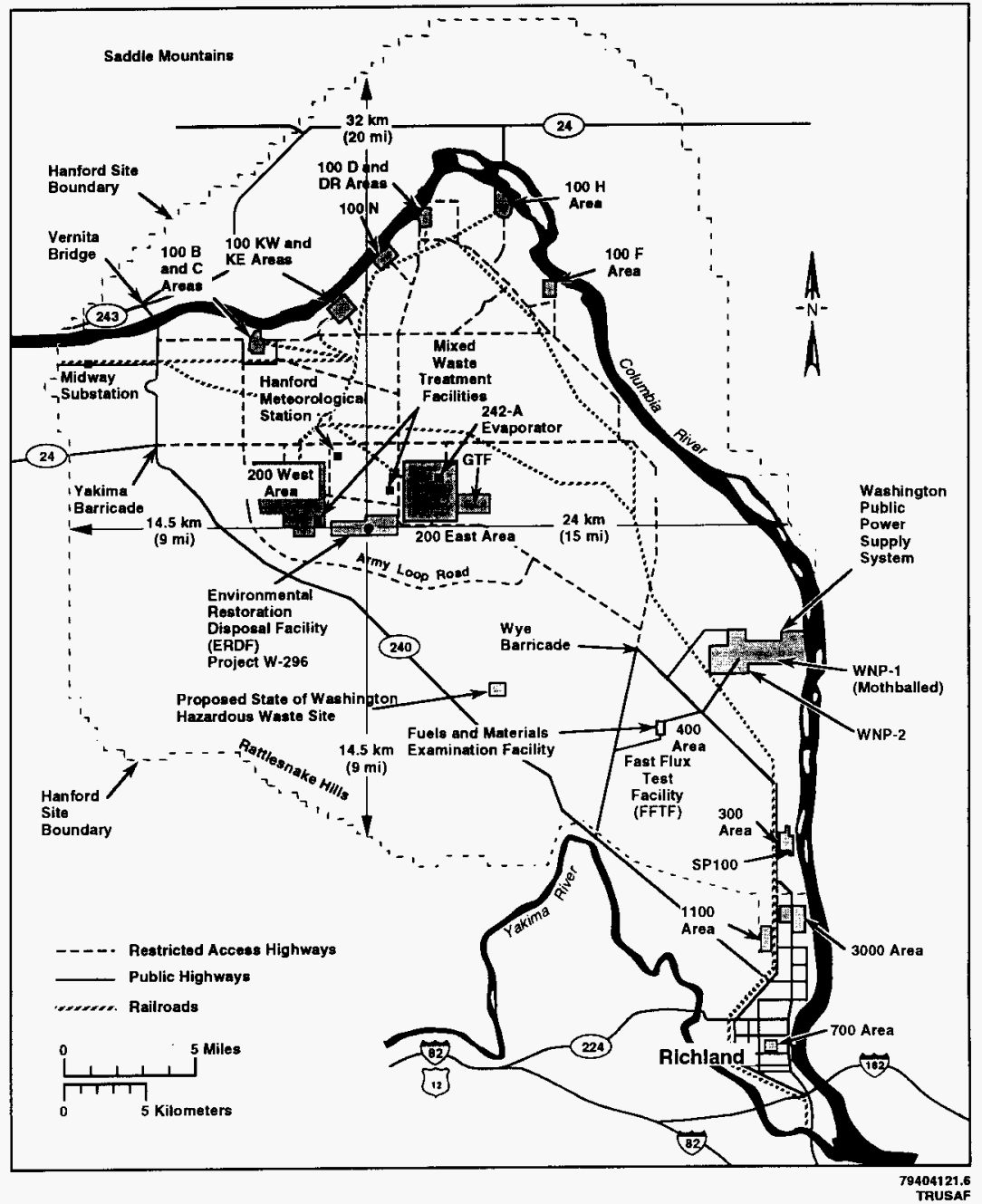


WHC-SD-WM-ISB-004 REV 1

Figure 2-2. The 200 West Area.

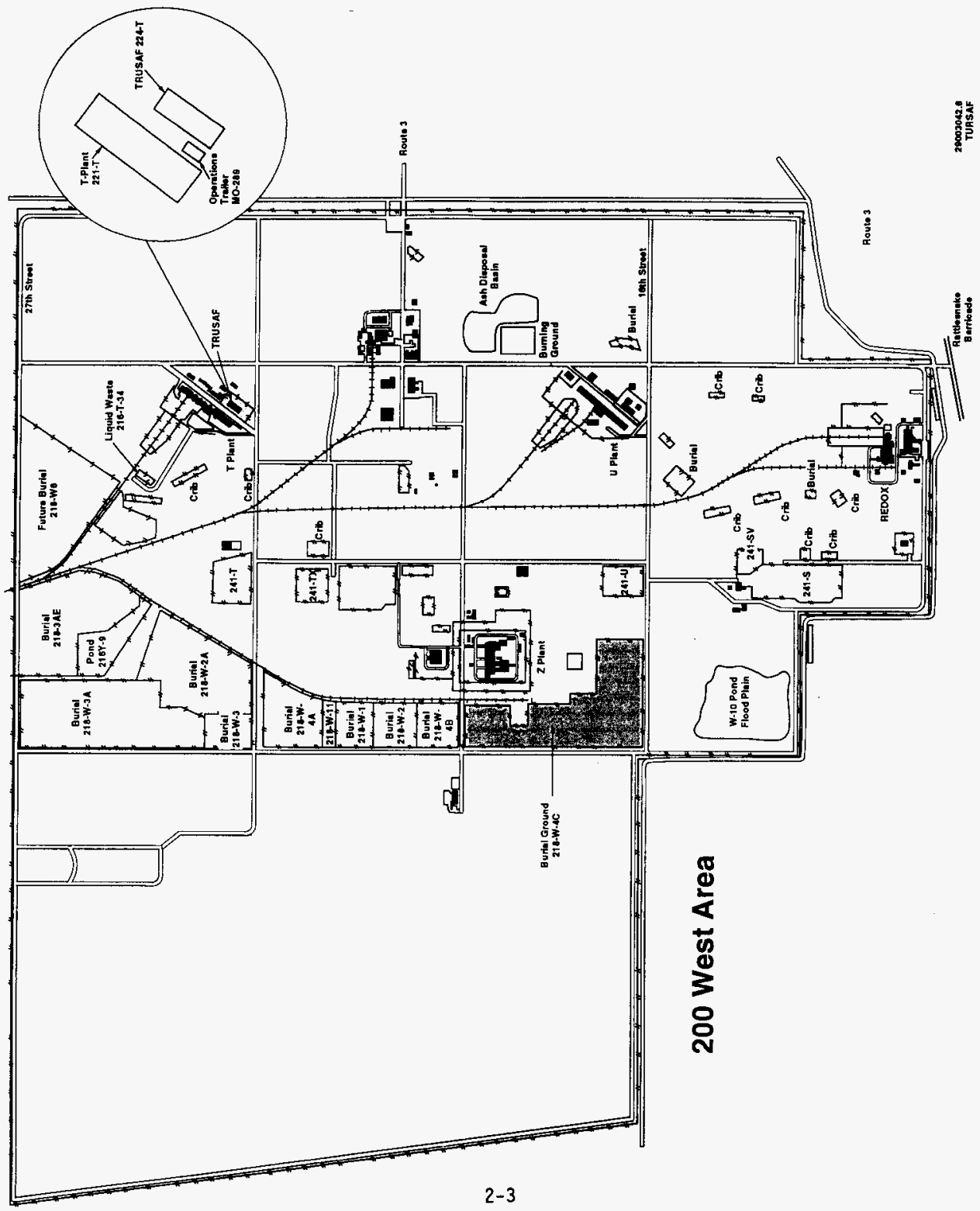


Figure 2-3. The Heating, Ventilating, and Air Conditioning System for the 224-T Building.

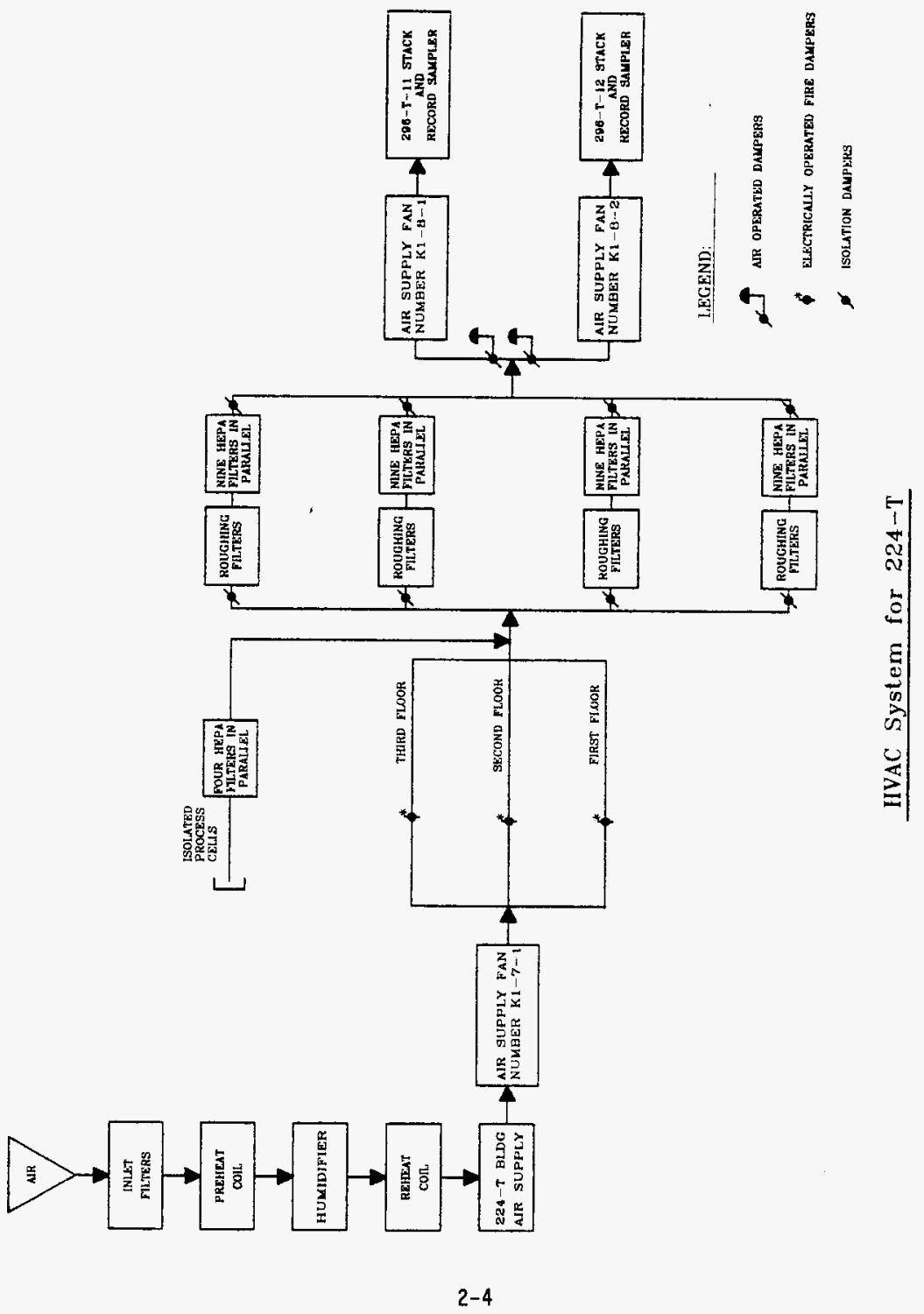


Figure 2-4. Floor Plan of the 224-T Building.
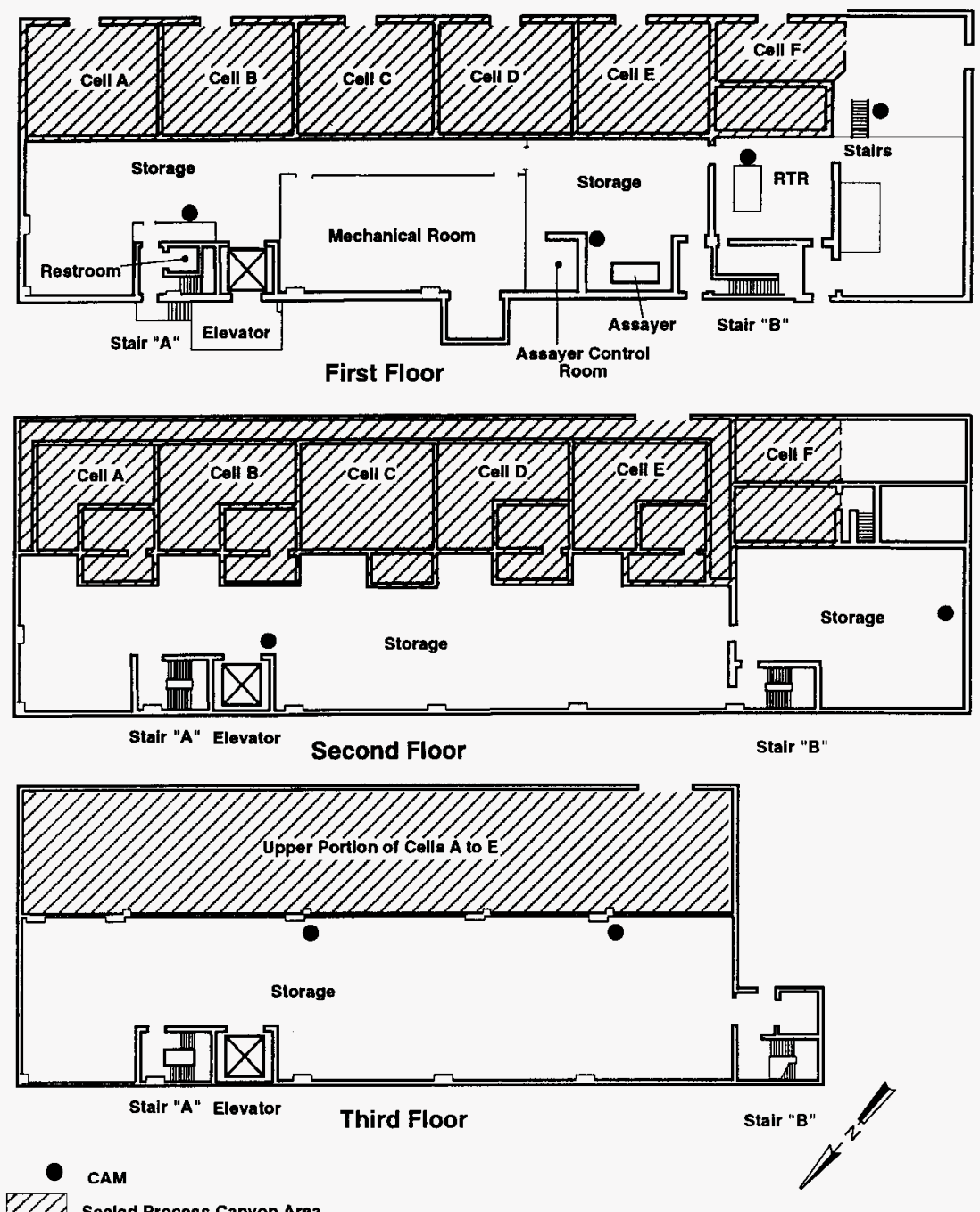

Sealed Process Canyon Area 
WHC-SD-WM-ISB-004 REV 1

Figure 2-5. Cross Section of the 224-T Building.

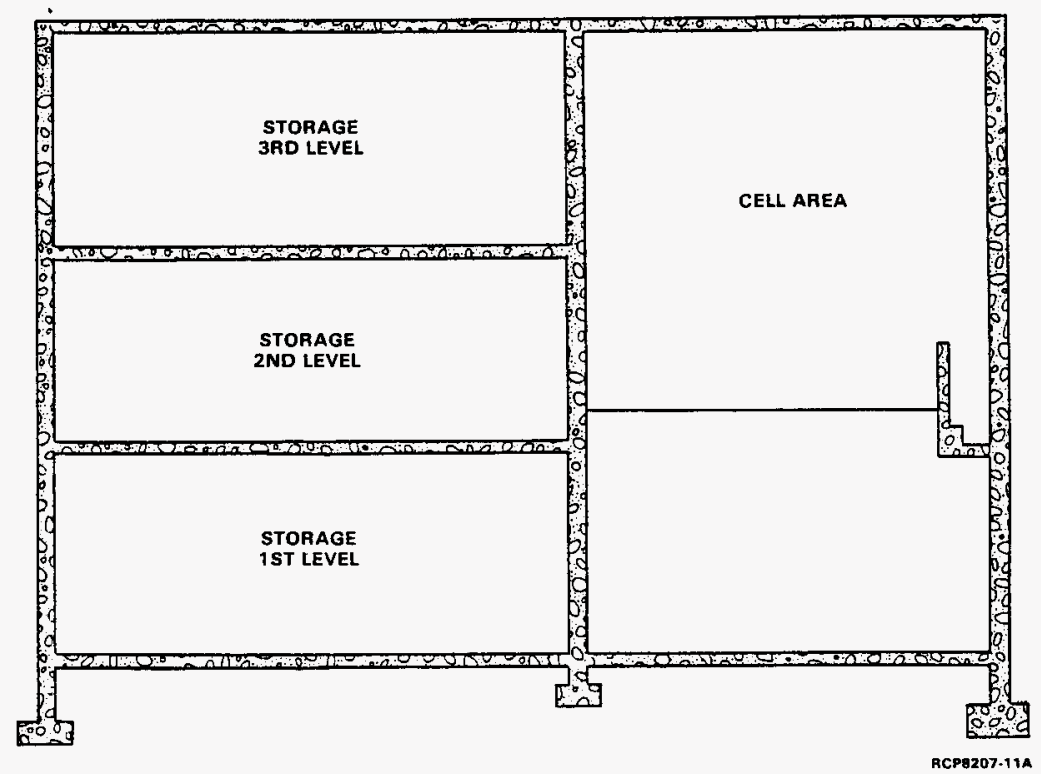


adjacent to stairway $A$. There is also an unloading platform off the elevator on the outside of the building. The roof contains the ventilation exhaust equipment and a penthouse sheltering the elevator mechanical equipment.

The first floor of the 224-T Building contains a rest room, a control room/operations office, a heating and ventilation mechanical room, an assayer room, a RTR room, and storage space. The storage space is in an open area with arrays marked off or painted on the floor. There is $\approx 175 \mathrm{~m}^{2}\left(1,900 \mathrm{ft}^{2}\right)$ of temporary storage area on the first floor.

The control room/operations office is the operations center. The TRU waste assayer is operated from this office, and operating logs and records are maintained here or in the operations trailer adjacent to 224-T in locked file cabinets. The main riser for the dry-pipe fire-protection system is also located in this office. The Operations Trailer, M0-289 is located adjacent to 224-T.

The mechanical room contains the supply ventilation fan, air humidifier (swamp cooler), instrument air compressor, motor control center, and indicator panels for the heating, ventilating, and air conditioning (HVAC) system.

The assayer room houses the TRU waste assayer. The radiography room houses the RTR system. The assayer room and radiography room may be used for the staging of containers, as long as $3 \mathrm{~m}(10 \mathrm{ft})$ is maintained between equipment and staged containers when assay or radiography is in progress.

The receiving area is located in the southeast corner of the first floor. A double-metal door is provided for entrance to the receiving area to allow movement of a forklift. This door remains locked except during waste handling operations. The receiving area also contains an electronic scale used to weigh the waste containers. The ceiling is two floors high in the extreme southeast portion of the receiving area. A portion of the ceiling is onty one floor high and contains a $910 \mathrm{~kg}$ (1-ton) crane. This crane is used for container overpacking operations and to place drums on a scale to be weighed. It is load tested and maintained on a regular basis.

A temporary staging area is located at the southeast end of TRUSAF. Waste accepted for evaluation against waste-acceptance criteria and potential storage is placed in the temporary staging area until off-loading operations are complete. The waste is transferred to the first-floor storage module when the receiving doors are closed.

The first-floor storage modules are flexible and are used for short-term storage before examination and transfer of waste to other locations (i.e., upper floor storage, initial generating units, low-level burial grounds, and Central Waste Complex). These modules are adjusted as necessary to accommodate the size and waste incompatibilities of each shipment. All TRU waste is separated into compatible modules. Drums containing $\leq 200 \mathrm{~g}$ of fissile material occupying $\geq 20 \%$ of the drum volume or $\leq 100 \mathrm{~g}$ of fissile material occupying $<20 \%$ of the drum volume are 1 imited to stacking 2 tiers high with an unlimited array size. By the waste-acceptance criteria noted in WHC-EP-0063, drums are limited to $\leq 200 \mathrm{~g}$ of fissile material for acceptance at TRUSAF. Based on the criticality limit of $400 \mathrm{~g}$ fissile material and the analysis in this safety analysis, a waiver as provided in WHC-EP-0063 can be 
used to allow individual drums up to $400 \mathrm{~g}$ fissile material to be stored. TRUSAF criticality safety documentation, Criticality Prevention Specification, Transuranic Waste Storage in 224-T, CPS-SW-149-0001, Rev. 0 (WHC 1989), has analyzed containers up to $400 \mathrm{~g}$. TRU mixed waste modules (labeled by waste category) are limited to arrays two containers wide and are separated from other modules by $0.76 \mathrm{~m}$ (30 in.) aisles, in accordance with WAC 173-303, "Dangerous Waste Regulations," Washington Administrative Code, as amended. The criteria for waste acceptance at TRUSAF shall be maintained by the Hanford Site solid waste-acceptance criteria detailed in WHC-EP-0063. Waste acceptance is based on inventory records, which are provided by the generator and document the drum contents.

There is $\approx 495 \mathrm{~m}^{2}\left(5,300 \mathrm{ft}^{2}\right)$ of interim storage area on the second floor. This storage area is open with arrays marked on the floor. Storage module locations will be adjusted as necessary to accommodate future waste storage. The individual process cell sample galleries protrude into the storage area and are sealed off. These galleries are not part of the storage area. There is $\approx 400 \mathrm{~m}^{2}\left(4,300 \mathrm{ft}^{2}\right)$ of interim storage area on the third floor.

Constant air sampling of operating and storage areas on each of the three floors is provided by continuous air monitors (CAMs), however, routine workplace air sampling is not required. Within the TRUSAF area of the building, air sampling/monitoring will meet the requirements of the HSRCM-1, Radiological Control Manual, Article 555, "Airborne Radioactive Material Monitoring." Sampling/monitoring is documented in Technical Assessment of Workplace Sampling at TRUSAF, WHC-SD-SQA-TA-20015, Rev. 0 (WHC 1995b). The building HVAC system provides a negative air pressure differential between the isolated process cells, the storage areas, and the environment (Section 2.4).

As documented in Design Criteria Supplement No. 2, Additional Modifications to 224-T Building (ARHCO 1972), the 224-T Building was upgraded to provide tornado resistance. Note that tornado resistance is no longer required for Hanford-Site nonreactor facilities. The modifications were as follows.

- Steel beams were attached horizontally to the original reinforced concrete walls and supported at column lines so that these walls were braced adequately to withstand a $280 \mathrm{~km} / \mathrm{h}(175 \mathrm{mi} / \mathrm{h})$ wind and a $53 \mathrm{~g} / \mathrm{cm}^{2}\left(0.751 \mathrm{~b} / \mathrm{in}^{2}\right)$ negative pressure transient.

- Shields over the exterior ventilation openings were provided to protect the containers stored in the building from tornado-generated missiles.

As noted in Design Criteria Structural Modifications 224-T Building, ARCHO-1929 (ARHCO 1971), the 224-T Building was also upgraded to provide seismic resistance. The modifications are as follows.

- Six vertical concrete buttresses were installed on the northeast side, and five concrete buttresses were installed on the southeast side.

- Unreinforced block walls were removed and filled in with reinforced concrete. 
Roof inspection results from (except for the portion of the roof that covers the cells) August 18, 1992 are documented in Roof Inspection Results for the 224-T Building (Chenault 1993). Analyses showed that the weight of the concrete roof $\left(\approx 3 \mathrm{kPa}\left[58 \mathrm{lb} / \mathrm{ft}^{2}\right]\right.$ and a live load of $\left.1 \mathrm{kPa}\left[20 \mathrm{lb} / \mathrm{ft}^{2}\right]\right)$ was used to verify that the allowed bearing and shear capacities were not exceeded. The margin of safety for flexure and shear was determined to be 0.14 and 3.38. As used here, margin of safety represents the fraction of allowable stress in excess of the maximum design stress. Based on these results, the roof over the facility, except for the cells is considered safe for personnel access. Because the cell area of TRUSAF could not be entered at the time of the inspection, the inside portion of the roof inspection could not be performed. Also, entry to the outside portion of the roof was not al lowed because of West inghouse Hanford Company (WHC) safety concerns. The roof over the cells was load tested using a robot on May 10, 1994. The test resulted in qualification for $227 \mathrm{~kg}(500 \mathrm{lb})$ total roof load. TRUSAF (224-T Building), including the roof, is designed to withstand an earthquake with a horizontal ground acceleration of $0.12 \mathrm{~g}$ and with a vertical ground acceleration $2 / 3$ of horizontal and sustain only minor, repairable damage. Under $0.25 \mathrm{~g}$ maximum ground acceleration with vertical acceleration at $2 / 3$ of horizontal, the building is designed to prevent serious damage to the waste containers, all confinement systems, and prevent ventilation flow reversal. The test results are documented in Load Test of 224-T Building Roof Deck and support Structure, WHC-SD-GN-TRP-20013, Rev. O (WHC 1994b).

\subsection{EQUIPMENT}

The neutron assayer produces a series of $10-\mu \mathrm{s}, 14-\mathrm{MeV}$ neutron pulses, $\left(2.0\right.$ to $3.0 \times 10^{6}$ neutrons per pulse, at repetition rates up to $100 \mathrm{pulses} / \mathrm{sec}$ ). The absolute minimum detection level has been determined under special conditions that may differ from actual operating conditions. Manufacturing information and operating experience indicate the instrument is capable of detecting TRU in milligrams. This system is capable of detecting TRU levels of $10 \mathrm{nCi} / \mathrm{g}$ in the waste matrix. The major components of the system include the following:

- Deuterium-tritium neutron generator

- Helium-3 proportional counters

- Control chassis

- Shielded assay chamber

- Drive chassis

- Chain-driven assayer platform $<2 \mathrm{ft}$ above the floor that receives and rotates drums

- Interlocks

- Warning lights.

Containers assayed above $200 \mathrm{~g}$ and below $400 \mathrm{~g}$ are stored in single tier 
arrays, even though the inventory sheets shows $\leq 200 \mathrm{~g}$ TRU. This maintains conservatism for criticality purposes. The assay results may have substantial error (or bias) for large TRU content drums, since the equipment is designed for accurate measurement of low quantities of fissile material, however, the error in measurement increases with higher quantities of fissile material. If the assayed quantity exceeds the waste-acceptance criteria of $<200 \mathrm{~g}$ of TRU, it may be stored at the TRUSAF, provided the drum does not exceed $400 \mathrm{~g}$. To conservatively determine the risk associated with the storage of these drums at the TRUSAF, the analysis provided by this document assumes a maximum TRU drum loading of $400 \mathrm{~g}$. The largest quantity assayed through July 1996 from $>5,000$ drums is $234 \mathrm{~g}$ TRU in one drum (WHC 1989). The RTR is used for nondestructive examination of TRUSAF container contents. The system consists of a radiation-shielded enclosure, a drum manipulator that raises and turns, a $320-k V x-r a y$ generating system, and an imaging and video recording system and consists of the following components:

- Door interlock (S-8)

- Image cover interlock (S-11)

- Emergency off switches (S-2 and S-10).

These RTR components prevent harmful x-ray exposures to facility workers. other TRUSAF equipment and applicable ratings are as follows:

- Four walk-behind electric forklifts rated at $910 \mathrm{~kg}(2,000 \mathrm{1b})$ fitted with drum-handling attachments rated at $455 \mathrm{~kg}(1,000 \mathrm{lb})$

- A $910 \mathrm{~kg}$ (1 ton) coffing hoist with a drum-handling attachment rated at $455 \mathrm{~kg}(1,000 \mathrm{lb})$

- An elevator rated at $3,630 \mathrm{~kg}(8,000 \mathrm{lb})$

- A walk-behind electric drum cart that will fit through doorways when maneuverability is required

- A manual hand cart for moving drums.

\subsection{CONFINEMENT SYSTEMS}

The 224-T Building ventilation was upgraded when it was converted to a storage facility. The exhaust high-efficiency particulate air (HEPA) filters and exhaust fans $\mathrm{K} 1-8-1$ and $\mathrm{Kl}-8-2$ at TRUSAF are nonsafety class. Failure of exhaust fans $\mathrm{K} 1-8-1$ and/or $\mathrm{Kl}-8-2$ could result in a reduction of negative pressure in the building, and allow an unanticipated radioactive release, primarily through the unsealed exterior door on each process cell. Failure of the exhaust HEPA filters could also result in an unanticipated radioactive release to the environment. These releases have been analyzed for postulated accidents in Section 3.1.3 and do not meet the established criteria for safety significant (Section 3.2.1). A HEPA filter failure and possible prediction of failure will be observed by a change on the differential pressure indicator. The present ventilation system, consisting of three fans, two exhaust, and one suppiy, is depicted in Figure 2-3. Final exhaust filtration consists of roughing filters and 99.95 rated efficiency HEPA filters. The HEPA filters are arranged in four banks (Figure 2-3). Each bank contains nine parallel 
HEPA filters in a three-by-three array.

Supply fan $\mathrm{Kl}-7-1$, rated at $944 \mathrm{~m}^{3} / \mathrm{min}\left(33,335 \mathrm{ft}^{3} / \mathrm{min}\right)$, provides supply air to the areas in the 224-T Building used for TRUSAF. Infiltration from unsealed exterior doors provides supply air to the process cells. The air from the isolated process cells vents through one stage of HEPA filters in a two-by-two array before joining the common exhaust plenum, which is upstream of final filtration.

Most of the building air enters a common exhaust plenum and flows through roughing and HEPA filters before being exhausted into the atmosphere. Approximately $23 \mathrm{~m}^{3} / \mathrm{min}\left(800 \mathrm{ft}^{3} / \mathrm{min}\right)$ of unfiltered air may escape into the environment through external doors that do not have airlocks (i.e., first floor exits, stairway exits on the third floor and roof, the elevator vestibule, and the receiving area).

The filtered air is exhausted by parallel exhaust fans (KI-8-1 and $\mathrm{K} 1-8-2)$ at a nominal rate of $462 \mathrm{~m}^{3} / \mathrm{min}\left(16,318 \mathrm{ft}^{3} / \mathrm{min}\right)$ each. Filtered air is discharged to the atmosphere through stacks 296-T-11 and 296-T-12. The stacks, located on the southwest end of the second-floor roof of the 224-T Building, are horizontal and exhaust toward the southwest.

The isolated process cells are maintained at a negative $(-0.8 \mathrm{wc})$ pressure with respect to the atmosphere and the storage areas $(-0.5 \mathrm{wg})$. This system provides four air changes per hour.

The facility maintains a constant negative pressure with respect to the atmosphere. The recommended ventilation rate of 4 to 8 air changes per hour is maintained, in accordance with the requirements of the Uniform Building code (UBC 1994). The system is capable of providing four air changes per hour with a single exhaust fan in operation.

The floors of TRUSAF have been sealed to provide containment of any liquids that may spill in accordance with waste storage facility design requirements. The floor penetrations were sealed, and all waste storage areas were painted with epoxy sealant. Each floor is sloped and has curbed entrances. The drain from the elevator shaft pit is plugged to prevent accidental flow of contaminated fluids into the buried French drain. Spilled water is pumped or mopped into a collection container, where it can be sampled before disposal. All TRUSAF drains, except the sanitary sewer, have been disconnected and sealed.

\subsection{SAFETY SUPPORT SYSTEMS}

\subsubsection{Fire Protection}

TRUSAF areas in the 224-T Building are protected by an automatic dry-pipe sprinkler system and an early-warning fire-detector system that use ionization-type detectors (i.e., smoke detectors). The sealed process cells are not protected by the systems listed above, but they are free from combustibles and isolated. Activation of the fire detection system or the sprinkler system does the following: 
- Actuates a single-stroke gong system installed within the building

- Indicates the location of the alarm by floor levels on a panel board outside the building near the entrance by the master fire-alarm box

- Sends a signal to the fire station

- Cuts off power to the air-supply fan and both exhaust fans.

The fire detection and sprinkler systems have supervised circuits. The stated response time of the Hanford Fire Department is $\approx 5 \mathrm{~min}$. The fire fighting category for TRUSAF is leve1 A; there is no restriction on the amount of water used for fire fighting. Although the facility limits the depth of water held in a room, this is not a governing factor in criticality control for these storage modules because any amount of water added to the array would be acceptable. Packaging, Storage, and Disposal of Solid Waste, CSAR 80-021 (Carter 1989), found that additional water would only result in over moderation and reduced reactivity.

\subsubsection{Air Sampling/Monitoring}

2.5.2.1 Radioactive Materials. The air sampling/monitoring is in accordance with HSRCM-1. WHC-SD-SQA-TA-20015, Rev. O (WHC 1995b), notes that TRUSAF is not required to have a routine workplace air-sampling program.

CAMs are placed between potential sources of airborne alpha contamination and occupational workers in the 224-T Building. Portable CAM units are on each level of the facility. TRUSAF CAMs are nonsafety class, controlled by the radiation protection program (Section 3.2.1). Personnel are required to evacuate the facility in the event of a CAM alarm. Work is initiated to repair the CAM in the event of a failure.

Exhaust stack record samplers are installed to document release/ nonrelease for reporting purposes. The cabinets storing the sampling equipment and the incandescent lights inside the cabinets (and their accessories) are nonsafety class (Section 3.2.1).

2.5.2.2 Hazardous Materials. There is no installed air sampling/monitoring equipment for hazardous materials. Portable air sampling/monitoring equipment is used as necessary, in accordance with WHC-CM-5-34, Solid Waste Disposa 7 Operations Administration.

\subsubsection{Safety Communications and Controls}

The communications system consists of an outside telephone system, emergency-evacuation audible alarm system, crash alarm, fire-alarm system, and CAMs. The fire-protection system alarms at the 224-T Building and the 200 Area Fire Station. 


\subsection{UTILITY DISTRIBUTION SYSTEMS}

Normal electrical power is supplied by a 13.8-kV three-phase line from the 251-W substation that is reduced from 13.8-kV to a $480 \mathrm{~V}$, three-phase system, and a $240 / 120 \mathrm{~V}$, single-phase system. Backup power is available to the building and is reduced from $2400 \mathrm{~V}$ to $240 / 120 \mathrm{~V}$. The backup power operates the fire system, various lights and electrical receptacles on all floors of the building. The building ventilation fans are not supplied with emergency power. The fire protection system is backed up with a battery pack. Battery power and emergency lights are located on the normal exit routes.

A small instrument-air system provides compressed air to the 224-T Building. The system consists of a single air compressor, drier, and storage tank. It is not on backup power. Air is used to modulate the dampers on the exhaust ventilation system. The dampers fail open, in that they will open if there is a loss of instrument air.

Only sanitary water is used at the 224-T Building. The water for the rest room and inlet air washer is supplied by a $10-\mathrm{cm}$ (4-in.) underground line coming off an 20-cm (8-in.) sanitary-water main. A separate 15-cm (6-in.) line off the same $20-\mathrm{cm}(8-$ in.) main supplies water to the fire-sprinkler system.

The assay and RTR room are each supplied with local heating and cooling by two 4 ton split system heat pumps. The system allows for maximum use and protection of the assayer and RTR equipment.

The 224-T Building sewer discharges to the 2607-W septic tank and tile field that also services the 221-T, 222-T, and 271-T Buildings. The heat pump effluent is piped to the fire riser drain. All other liquid effluent piping from TRUSAF has been disconnected and effluent penetrations from TRUSAF are sealed.

\subsection{PROCESS DESCRIPTION}

TRUSAF operations are conducted in accordance with authorized procedures by qualified staff. The staff is trained and certified in accordance with WHC-CM-5-34, Solid Waste Disposal Operations Administration. TRUSAF process flow is depicted in Figure 2-6. The sequence of this process is as follows.

- The waste generator obtains advance approval for storage in TRUSAF through waste acceptance contact.

- The waste generator schedules shipment to TRUSAF.

- The shipment is checked for acceptability before it is unloaded.

- The integrity of each container is verified.

- The containers are unloaded and assigned data packages.

- The containers are placed in temporary storage. 
Figure 2-6. Transuranic Waste Storage and Assay Facility Process Flow (Ground Floor).

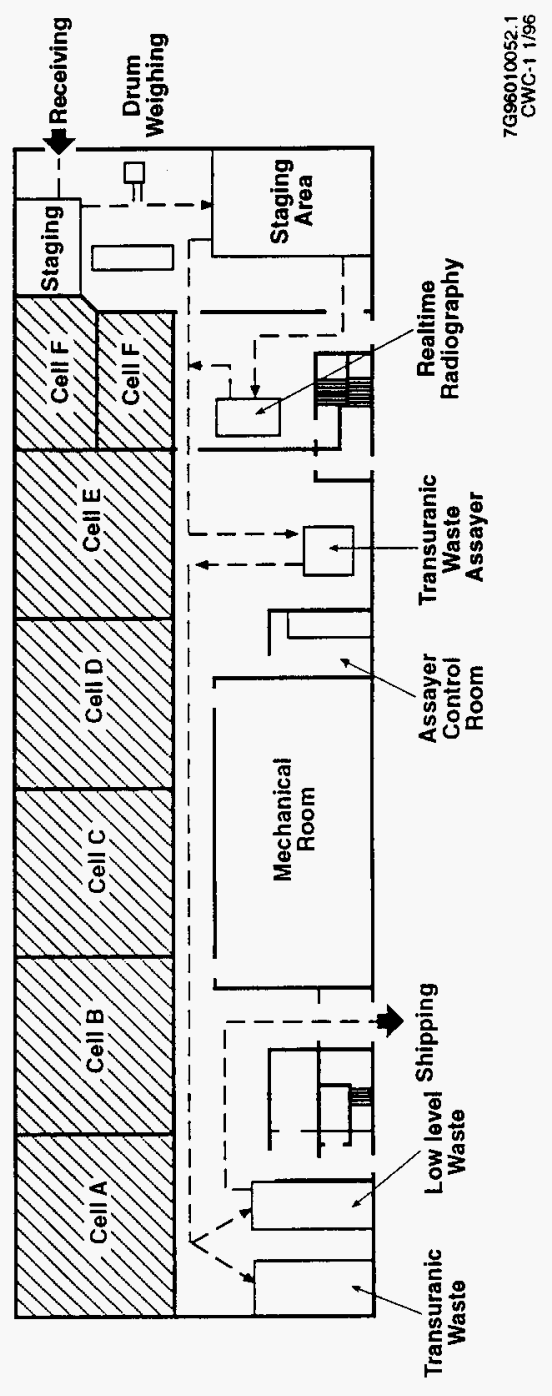


- The containers are weighed.

- The containers may receive an RTR examination in accordance with the solid waste verification program (assay may precede RTR examination).

- The containers may be assayed (assay may precede RTR examination).

- The drums are segregated and temporarily stored.

- The drums that are certified for TRUSAF storage are moved into interim storage.

- Drums that have been designated to be returned are sent back to the generator.

- Low-level waste (LLW) will be sent to the low-level burial grounds for disposal. Low-level mixed waste (LLMW) will be sent to the Central Waste Complex (CWC) for storage.

For newly generated and retrieved waste, the waste generator contacts the Solid Waste Disposal division for assistance in meeting the requirements of WHC-EP-0063 before shipping any waste packages to TRUSAF. The shipment is then scheduled through the Solid Waste Management waste scheduler.

When a shipment is received at TRUSAF it is checked for acceptability before it is unloaded. Care is taken to avoid damaging the containers during the unloading process. Lift tailgates lower the containers from the transport vehicle. Material handling equipment weight limits are not exceeded. Handcarts are used to move the containers to the initial staging area. Signs and barricades are posted around the area to communicate the potential radiation hazard. The drum identification numbers and dates of receipt are recorded in the receipt and storage log book. A data package prepared for each container accompanies the container throughout the process. The drums are stored temporarily in the staging area (Figure 2-6). Retrieved drums are always segregated from other drums.

Drums are weighed using a digital scale. Either a hand-operated forklift with a drum-handling attachment or electric crane equipment with drum-handling attachments is used to $\mathrm{place}$ the drums on the scale. A label indicating the drum weight in kilograms is applied to the container. The forklift or crane raises the drum off the scale and lowers it to the floor.

Containers slated for verification are then moved by a hand-operated forklift to the RTR operating room. The need for verification is based on the performance history of the waste generator. The x-ray allows a visual overview of the waste inside to see if the identified waste is in generat agreement with documentation and meets waste verification criteria. The RTR will be used to assist in identification and characterization of the contents of received waste.

The container is loaded into the radiography system by a hand-operated forklift with a drum-handling attachment. The drum can be raised and turned during the examination using the manipulator controls. Audio and visual notes 
are recorded on a video cassette recorder tape to provide real-time imaging. The tape is labeled with the drum ID number, date, and time recorded.

A safety checklist is completed before energizing the radiography system. Items on this checklist include verification that the radiation work permit has not expired, warning lights are operational, and unauthorized personnel are cleared from the working area. The operations and maintenance $\log$ is also completed. The log covers items such as physical damage and maintenance performed on the RTR system.

The drums may be assayed to check TRU activity. Waste containers $\geq 100 \mathrm{nCi} / \mathrm{g}$ are considered to be TRU waste. The drums are loaded into the assayer using a hand-operated forklift with a drum-handling attachment.

\subsubsection{Retrieved Waste}

Retrieved waste drums will be accompanied by radioactive shipment records that include a copy of the original burial record, a drum inspection form, and a pre-shipment checklist.

A hazardous waste manifest will also accompany the drum if existing records show that hazardous wastes are contained in the drum. A print out of the data in the Solid Waste Information Tracking System (WHC 1995d) will be available at TRUSAF for additional information. The documentation will be used to initially characterize the containers and to provide a comparison during the nondestructive assay examination. These examinations will be used to assess the accuracy of the historical assay data, and to estimate waste material contents. Nondestructive examination retrieved waste data forms and visual inspection data forms will be sent to TRUSAF as verification of meeting TRUSAF entry requirements.

Container integrity is verified, in accordance with 49 CFR 173 , "Shippers-General Requirements for Shipments and Packaging," Code of Federal Regulations, as amended. The container may be carbon steel or galvanized 208-L (55-gal) drum DOT type-A containers for waste retrieved for characterization. The container wall thickness will be measured in situ at the retrieval site to verify that the wall thickness is the minimum wall thickness of a $17 \mathrm{H}$ type-A 208-L (55-gal) drum and the drum has no evidence of a breach condition. The container will not be accepted at TRUSAF if it does not have the required wall thickness of $>1.07 \mathrm{~mm}(0.042 \mathrm{in.})$, in accordance with the Resource Conservation and Recovery Act of 1976, 42 USC 6901, et seq., permit.

\subsubsection{Newly Generated Waste}

The approved container for newly generated waste in TRUSAF is the U.S. Department of Transportation (DOT) 17C or its equivalent UN1A2. The documentation for newly generated waste is examined to assure it is proper and complete. This documentation includes the following:

- Radioactive shipment record

- TRU waste storage record 
- WIPP certification checklist

- Contents inventory sheet.

Hazardous waste manifests are also required if hazardous constituents are present in the containers.

Only required personnel are authorized to be in the assay area when the system is energized. The equipment is locked when not in use. Results from the assay and RTR determine where drums are temporarily stored. The temporary storage area is located on the first floor and is divided into the areas listed below.

- Certified for TRUSAF Storage - drums to be moved to the interim storage areas on the upper floors.

- Certifiable WIPP - drums that are in accordance with the WIPP wasteacceptance criteria and are to be placed in interim storage pending shipment to the WIPP.

- Retrieved TRU Storage - the retrieved drums that exceed $100 \mathrm{nCi} / \mathrm{g}$ will be placed on hold pending further examination and/or treatment in the Waste Receiving and Processing Facility (WRAP).

- Temporary Flamable Storage - drums that are managed as flammable. Potentially flammable drums are sent to the CWC for proper storage as soon as possible.

- Low-level - drums $<100 \mathrm{nCi} / \mathrm{g}$ TRU activity and are relabeled and buried as LLW (existing TRU labels are destroyed to avoid confusion).

- Hold - drums that have one or more hold points checked on the traveler form and are held for further analysis.

- Return to Generator - drums that have been designated to be returned by the TRUSAF manager.

A11 TRUSAF waste packages that successfully meet WIPP certification requirements are placed in interim storage pending shipment to the WIPP. Waste drums received from pilot retrieval that do not meet waste-acceptance criteria will be processed, analyzed, and stored at TRUSAF until subsequent treatment in the WRAP Facility. Newly generated waste drums that do not meet WIPP waste acceptance may be returned to the generator or transferred to approved storage units. Waste drums identified as LLW will be routed to the low-level burial grounds for disposal. Radioactive LLMW will be routed to the CWC for storage. The data package is filed before the containers are placed in interim storage. Interim storage areas are located on the second and third floor. Retrieved drums will be segregated from certified drums.

The drums are stored in modules with drums stacked no more than two high. This is a physically imposed limit because of the ceiling height and installed services and utilities (e.g., lighting). Each module is labeled for traceability of the drums. Each drum has a module recorded in the receipt and storage $\log$ book under the heading of final disposition. A hand-operated 
forklift with a drum-handling device is used to stack the drums. The height of the forklift is limited by a switch. A check of overhead obstruction is done before exceeding the limit. Each tier of drums is separated by a sheet of at least $13-\mathrm{mm}(1 / 2-i n$.$) fire retardant plywood or another material of$ equivalent fire retardancy. Without a structural analysis, stacked drums are not to exceed the maximum floor loadings listed below:

- First floor

- Second floor

- Third floor

- Elevator

$$
\begin{aligned}
& 1,130 \mathrm{~kg}(2,500 \mathrm{lb}) / \text { single stack } \\
& 272 \mathrm{~kg}(600 \mathrm{lb}) / \text { single stack } \\
& 363 \mathrm{~kg}(800 \mathrm{lb}) / \text { single stack } \\
& 3,630 \mathrm{~kg}(8,000 \mathrm{lb}) \text { capacity. }
\end{aligned}
$$

The drums are arranged with aisles around the modules to allow easy access through the storage areas. Drums with thermal wattage $1 \mathrm{~W} / \mathrm{ft}^{3}$ $\left(35 \mathrm{~W} / \mathrm{m}^{3}\right)$ are segregated and stored in single tiers at 1 east $0.91 \mathrm{~m}(3 \mathrm{ft})$ away from other stored drums.

The drums remain in storage until shipment to the WIPP. Retrieved TRU waste drums will be held for treatment in the WRAP Facility. The anticipated shipping years to WRAP are 1996 through 2013. Drums may be shipped from TRUSAF to other interim storage facilities depending on future TRUSAF space requirements and interim storage construction. 


\subsection{INTERIM SAFETY BASIS EVALUATION}

The following sections present the safety aspects considered in this ISB. Included is a description of how operation of TRUSAF will ensure the protection of operating personnel and the public. A summary of natural phenomena, site characteristics affecting the safety analysis, and the effects of nearby facilities on the safe operation of TRUSAF are in this chapter. The radiological impact to onsite and offsite receptors from postulated accidents is also presented.

\subsection{HAZARD ANALYSIS}

\subsubsection{Hazard Categorization}

Hazard categorization determines the application of the graded approach to safety analysis. Safety analysis for Hazard Category l facilities would be much more extensive and complex than the analysis for a facility with less hazards (e.g., Hazard Category 3 facilities).

DOE Order 5480.23 defines a facility's hazard category based on the consequences of unmitigated releases determined by a hazard analysis of the facility's nuclear activities. These are then classified as Hazard Category 1, 2, or 3 hazards based on the following definitions:

- Hazard Category 1. Facilities that hazard analysis shows the potential for significant offsite consequences. This category is generally assigned to Hazard Category A nuclear reactors and facilities designated by the Program Secretarial officer. DOE Order 5480.6, Safety of Department of Energy-Owned Nuclear Reactors, defines Hazard Category A nuclear reactors as those having a steadystate power level of $>20$ MWt.

- Hazard Category 2. Facilities that hazard analysis shows the potential for significant onsite consequences.

- Hazard Category 3. Facilities that hazard analysis shows the potential for only significant localized consequences.

DOE-STD-1027-92 provides guidance on determination of preliminary hazard categories based on comparison of individual radionuclides to the threshold quantities for Hazard Category 2 and 3 . The ratios between the facility inventory at risk and the category threshold quantities for each radionuclide are summed if all the individual quantities are less than the threshold quantities. If a facility falls below the Hazard Category 3 threshold, it is exempt from the requirements of DOE Order 5480.23. Such a facility should, however, have administrative controls in place to ensure minimum values are not exceeded through the introduction of new radioactive material.

The Hazard Category 2 threshold quantities are used to determine the facility hazard categorization if the Hazard Category 3 facility quantities are exceeded. The facility is Hazard Category 3 if the Hazard Category 2 threshold quantities are not exceeded. The facility is Hazard Category 2 
if it contains more than the Hazard Category 2 threshold quantities of radioactive material and it is not a Hazard Category $A$ reactor or designated as Hazard Category 1 by the Program Secretarial officer.

TRUSAF has an inventory of over $47 \mathrm{~kg}$ (104 1b) of plutonium. The threshold value for Hazard Category 3 is 8.4 grams of ${ }^{239} \mathrm{Pu}$. As physical separation precludes the potential for criticality, the threshold quantity for Hazard Category 2 is 900 grams of ${ }^{239} \mathrm{Pu}$. TRUSAF has an initial designation as Hazard Category 2, since it contains more than the Hazard Category 2 quantity of plutonium and is not a Category A reactor or designated as Hazard Category 1 by the Program Secretarial officer. This preliminary hazard categorization, based on the threshold quantity of DOE-STD-1027-92 is the basis for requiring the quantitative accident analysis provided in the ISB.

TRUSAF is classified as a limited control facility, in accordance with WHC-CM-5-36, Chapter 4-29 because the TRU fissile content is in such a form and quantity that a criticality is incredible. This is documented in Criticality Prevention Specification, Transuranic Waste Storage in 224-T (WHC 1989).

\subsubsection{Hazards Analysis Affect on Hazard Categorization}

Following completion of the accident analysis presented in section 3.1 .4 , it was concluded that operation of the TRUSAF is consistent with the criteria of DOE-STD-1027-92, for defining a facility as having a potential for only significant localized consequences. See section 3.1.5, Basis for Inventory Control. Hence, application of any DOE Orders or Standards that reference hazard categorization for purposes other than safety analysis report (SAR) preparation will be based on the TRUSAF having a potential for only significant localized consequences.

\subsubsection{Preliminary Hazards Analysis}

The preliminary hazards analysis is performed to identify the hazards and evaluate their preventing and mitigating features. The analysis also ranks the hazards on a common scale that is used to select the potential accidents that require further analysis.

Potential hazards at TRUSAF were identified by a combination of facility and plant operating procedure reviews. Facility drawings were examined. The facility was examined on a tour with the cognizant engineer. TRUSAF Hazards Identification and Evaluation, WHC-SD-WM-SAR-025, Rev. 0 (WHC 1987); 224-T Transuranic Waste Storage and Assay Faci7ity Dangerous Waste Permit Application, RL-91-51, Rev. 0 (RL 1992); 224-T TRUSAF Building Upgrade, WHC-SD-WM-ES-288, Rev. 0 (WHC 1994d); and the criticality prevention document (WHC 1989) were reviewed in the process. Solid Waste Plant Operating Procedure, Receive/Assay/Store TRU Waste in 224-T, SW-100-020 (WHC 1994c) and Solid Waste Plant Operating Procedures, Package and Transport Radioactive Waste, SW-100-030 (WHC 1994e), were al so scrutinized. WHC-SD-WM-SAR-058, Rev. 0 (WHC 1994a), was reviewed to determine additional hazards associated with drums generated from the Pilot Retrieval Project. Multiple discussions were held with the cognizant engineer and with other safety engineers. 
The identified hazards, with the exception of those routinely accepted by private industry or the public, were evaluated to develop consequence and frequency estimates and to help evaluate and select accident scenarios requiring further analysis. Scenarios were postulated and assigned qualitative estimates for probability and severity. These estimates were benchmarked with comparisons to potential hazards evaluated at other WHC radioactive waste storage facilities (e.g., the CWC, WRAP 1, and the SWBG). Table 3-1 documents the hazard analys is for TRUSAF.

The hazard analysis identifies a large number of potential accidents. It is necessary to select a reasonable subset of accidents for detailed analysis. Both frequency and consequence must be considered when selecting this subset. The accidents should bound the risk of facility operations.

A four-by-four probability and consequence ranking matrix (Figure 3-1) was developed using DOE-STD-3009-94, Preparation Guide for U.S. Department of Energy Nonreactor Nuclear Facility Safety Analysis Reports to separate the lower-risk accidents adequately assessed by hazards evaluation from higherrisk accidents that may warrant additional quantitative analysis. Tables 3-2 and 3-3 provide definitions of probability and consequences used for binning potential accidents.

Application of the probability and consequence ranking matrix identified the forklift accident and the drum explosion hazards as situations of major concern. Several of the accident scenarios were identified as situations of concern. At least one scenario was selected for accident analysis in each of the four accident groups. The accidents selected were judged to bound the major types of accidents based upon probability and consequence considerations.

- Mechanical Release - a number of credible accidents that result in a mechanical release, including container corrosion, container overpressurization, and a container handling accident, were identified in the hazards analysis. A container handling accident was selected for analys is because it was judged to have greater consequences than a drum corrosion scenario and a greater frequency than an overpressurization scenario.

- Fire/Explosion - a drum fire, a drum explosion, and a vehicle fire were selected for detailed analysis. Although a range fire is an anticipated event at the Hanford Site, it was not analyzed based on its extremely unlikely probability of impacting the facility and postulated low consequences.

- External Events and Natural Phenomenon - the seismic event was the only natural phenomena selected for further analysis because the risk associated with the seismic event was judged to bound all of the other natural phenomena. The sole external event considered, an aircraft crash, is an incredible event and thus was not selected for analysis. The probable maximum flood is estimated to reach the southwestern portion of the 200 West Area in case of a precipitation event in which the Cold Creek watershed is flooded. Although 
Table 3-1. Transuranic Waste Storage and Assay Facility Hazard Analysis. (4 sheets)

\begin{tabular}{|c|c|c|c|c|c|c|c|}
\hline $\begin{array}{l}\text { Accident } \\
\text { group }\end{array}$ & $\begin{array}{l}\text { Accident } \\
\text { scenarios }\end{array}$ & Target/potential consequences & Preventative/mitigating features & Probability(a) & Severity ${ }^{(b)}$ & Rank & $\begin{array}{l}\text { Scenario } \\
\text { selected for } \\
\text { full analysis? }\end{array}$ \\
\hline $\begin{array}{l}\text { Mechanical } \\
\text { release }\end{array}$ & $\begin{array}{l}\text { Forklift drops } \\
\text { a container or } \\
\text { causes } \\
\text { containers to } \\
\text { rupture }\end{array}$ & $\begin{array}{l}\text { Potential dose to } \\
\text { onsite/offsite receptor and } \\
\text { exposure to occupational } \\
\text { worker. Potential injury to } \\
\text { occupational worker. } \\
\text { Contamination of the facility. }\end{array}$ & $\begin{array}{l}\text { 1. Hand-operated, walk-behind forklifts } \\
\text { are used to move drums. } \\
\text { 2. Packaging requirement for double } \\
\text { confinement } \\
\text { 3. Operator training } \\
\text { 4. Container handling procedures } \\
\text { 5. Equipment maintenance and inspection } \\
\text { 6. HEPA filtered ventilation system } \\
\text { with negative pressure }\end{array}$ & Anticipated & 11 & OMC & res \\
\hline & $\begin{array}{l}\text { Crane drops } \\
\text { containers } \\
\text { causing then to } \\
\text { rupture }\end{array}$ & $\begin{array}{l}\text { Potential dose to } \\
\text { onsite/offsite receptor and } \\
\text { exposure to occupational } \\
\text { worker. Potential injury to } \\
\text { occupational worker. } \\
\text { Contamination of the Facility. }\end{array}$ & $\begin{array}{l}\text { 1. Packaging requirement for double } \\
\text { confinement } \\
\text { 2. Operator training } \\
\text { 3. Operating procedures (hoisting and } \\
\text { rigging manual) } \\
\text { 4. Equipment maintenance and inspection } \\
\text { 5. HEPA filtered ventilation system } \\
\text { with negative pressure }\end{array}$ & Unl ikely & 11 & OC & No \\
\hline & $\begin{array}{l}\text { Stacking error } \\
\text { unbalances } \\
\text { containers and } \\
\text { causes } \\
\text { containers to } \\
\text { fall }\end{array}$ & $\begin{array}{l}\text { Potential injury to } \\
\text { occupational worker. }\end{array}$ & $\begin{array}{l}\text { 1. Operating procedures for handling } \\
\text { containers } \\
\text { 2. Operator training } \\
\text { 3. 2-tier stacking limit } \\
\text { 4. Fire-retardant plywood layer between } \\
\text { the tiers of containers }\end{array}$ & Anticipated & I I I & oc & No \\
\hline & $\begin{array}{l}\text { External } \\
\text { container rust } \\
\text { results in } \\
\text { breached } \\
\text { container }\end{array}$ & $\begin{array}{l}\text { Potential exposure to } \\
\text { occupational worker. } \\
\text { Contamination of the facility. }\end{array}$ & $\begin{array}{l}\text { 1. Packaging requirements for double } \\
\text { confinement } \\
\text { 2. Operating procedures for storage } \\
\text { containers } \\
\text { 3. HEPA filtered ventilation system } \\
\text { with negative pressure }\end{array}$ & Unt ikely & III & NOC & No \\
\hline
\end{tabular}


Table 3-1. Transuranic Waste Storage and Assay Facility Hazard Analysis. (4 sheets)

\begin{tabular}{|c|c|c|c|c|c|c|c|}
\hline $\begin{array}{l}\text { Accident } \\
\text { group }\end{array}$ & $\begin{array}{l}\text { Accident } \\
\text { scenarios }\end{array}$ & Target/potential consequences & Preventative/mitigating features & Probability(a) & Severity ${ }^{(b)}$ & Rank & $\begin{array}{l}\text { Scenario } \\
\text { selected for } \\
\text { full analysis? }\end{array}$ \\
\hline \multirow[t]{4}{*}{$\begin{array}{l}\text { Mechanical } \\
\text { release } \\
\text { (Cont inued) }\end{array}$} & $\begin{array}{l}\text { Gas buildup } \\
\text { causes } \\
\text { containers to } \\
\text { swell and } \\
\text { rupture }\end{array}$ & $\begin{array}{l}\text { Potential unacceptable dose to } \\
\text { maximum onsite receptor and } \\
\text { exposure to occupational } \\
\text { worker. Contamination of the } \\
\text { facility. }\end{array}$ & $\begin{array}{l}\text { 1. Packaging requirements for double } \\
\text { confinement } \\
\text { 2. Packaging requirements to preclude } \\
\text { volume increases of waste } \\
\text { 3. Operat ing procedures for inspect ing } \\
\text { waste containers to detect leaking } \\
\text { condition } \\
\text { 4. Container has either a vent clip or } \\
\text { HEPA fitter to vent internal gas } \\
\text { pressure } \\
\text { 5. HEPA filtered ventilation system } \\
\text { with negative pressure }\end{array}$ & Unlikely & II & oc & No \\
\hline & $\begin{array}{l}\text { Internal } \\
\text { container } \\
\text { corrosion } \\
\text { results in } \\
\text { breached } \\
\text { container }\end{array}$ & $\begin{array}{l}\text { Potential exposure to } \\
\text { occupational worker. } \\
\text { Contamination of the facility. }\end{array}$ & $\begin{array}{l}\text { 1. Packaging requirements for double } \\
\text { confinement } \\
\text { 2. Packaging requirements for corrosive } \\
\text { wastes } \\
\text { 3. HEPA filtered ventilation system } \\
\text { with negative pressure }\end{array}$ & Anticipated & III & MOC & No \\
\hline & $\begin{array}{l}\text { Elevator } \\
\text { failure causes } \\
\text { drum rupture }\end{array}$ & $\begin{array}{l}\text { Potential dose to } \\
\text { onsite/offsite receptor and } \\
\text { exposure to occupat inal } \\
\text { worker. Potent ial injury to } \\
\text { occupat ional worker. } \\
\text { Contamination of the facility. }\end{array}$ & $\begin{array}{l}\text { 1. Elevator maintenance and inspection. } \\
\text { 2. Elevator maximum load limit. } \\
\text { 3. HEPA filtered vent } i \text { lation system } \\
\text { with negative pressure } \\
\text { 4. Overpacking of drums with suspect } \\
\text { integrity, in accordance with } \\
\text { procedures found in Overpack } 55 \\
\text { Gallon Drums, SH-100-095, Rev. 0-A } \\
\text { (HHC 1994f) }\end{array}$ & $\begin{array}{l}\text { Extremely } \\
\text { unl ikely }\end{array}$ & II & MOC & No \\
\hline & $\begin{array}{l}\text { Failure of } \\
\text { exhaust fans or } \\
\text { loss of power } \\
\text { results in loss } \\
\text { of negative air } \\
\text { pressure } \\
\text { differential }\end{array}$ & $\begin{array}{l}\text { Potential spread of } \\
\text { contamination within facility. } \\
\text { Potential release to } \\
\text { environment through unsealed } \\
\text { external process cell doors. }\end{array}$ & $\begin{array}{l}\text { 1. Packaging requirements for double } \\
\text { confinement. } \\
\text { 2. Operating procedure su- } 100-020 \\
\text { requires evacuation of facility } \\
\text { given toss of both exhaust fans (HHC } \\
\text { 1994c). }\end{array}$ & Anticipated & IV & MOC & No \\
\hline
\end{tabular}


Table 3-1. Transuranic Waste Storage and Assay Facility Hazard Analysis. (4 sheets)

\begin{tabular}{|c|c|c|c|c|c|c|c|}
\hline $\begin{array}{l}\text { Accident } \\
\text { group }\end{array}$ & $\begin{array}{l}\text { Accident } \\
\text { scenarios }\end{array}$ & Target/potential consequences & Preventative/mitigating features & Probabitity(a) & Severity ${ }^{(b)}$ & Rank & $\begin{array}{l}\text { Scenario } \\
\text { selected for } \\
\text { full analysis? }\end{array}$ \\
\hline \multirow[t]{5}{*}{$\begin{array}{l}\text { Fire/explosio } \\
\text { n release }\end{array}$} & Drum fire & $\begin{array}{l}\text { Potential unacceptable dose to } \\
\text { maximum onsite receptor and } \\
\text { exposure to occupational } \\
\text { worker. Potential injury or } \\
\text { fatality to occupational } \\
\text { worker. Contamination of the } \\
\text { facility. Facility/ property } \\
\text { damage. }\end{array}$ & $\begin{array}{l}\text { 1. Fire suppression system (dry pipe } \\
\text { sprinklers) } \\
\text { 2. Equipment, vehicle, and facility } \\
\text { maintenance } \\
\text { 3. Hanford Fire Department } \\
\text { 4. HEPA filtered ventilation system } \\
\text { with negative pressure }\end{array}$ & $\begin{array}{l}\text { Extremely } \\
\text { unt ikely. }\end{array}$ & I & oc & Yes \\
\hline & Vehicle fire & $\begin{array}{l}\text { Potential unacceptabte dose to } \\
\text { maximum onsite receptor and } \\
\text { exposure to occupational } \\
\text { worker. Potential injury or } \\
\text { fatality to occupational } \\
\text { worker. }\end{array}$ & $\begin{array}{l}\text { 1. Equipment, vehicle, and facility } \\
\text { maintenance } \\
\text { 2. Concrete building prevents vehicle } \\
\text { from penetrating } \\
\text { 3. Hanford Fire Department }\end{array}$ & $\begin{array}{l}\text { Extremety } \\
\text { unl ikely }\end{array}$ & 11 & oc & No \\
\hline & Range fire & $\begin{array}{l}\text { Potentiat injury to } \\
\text { occupational worker. }\end{array}$ & $\begin{array}{l}\text { 1. Procedures for good housekeeping } \\
\text { 2. Hanford Fire Department } \\
\text { 3. Facility constructed of nonflammable } \\
\text { materials } \\
\text { 4. Fire break surrounding buildings }\end{array}$ & $\begin{array}{l}\text { Extremely } \\
\text { unl ikely }\end{array}$ & III & NOC & No \\
\hline & $\begin{array}{l}\text { Hydrogen } \\
\text { explosion in } \\
\text { container with } \\
\text { resultant fire. }\end{array}$ & $\begin{array}{l}\text { Potential unacceptable dose to } \\
\text { maximum onsite receptor and } \\
\text { exposure to occupational } \\
\text { worker. Potential injury or } \\
\text { fatality to occupational } \\
\text { worker. }\end{array}$ & $\begin{array}{l}\text { 1. Container has a vent clip or HEPA } \\
\text { filter to vent internal gas pressure } \\
\text { 2. HEPA filtered ventilation system } \\
\text { with negative pressure }\end{array}$ & Unl ikely & 1 & OAC & Yes \\
\hline & $\begin{array}{l}\text { Volatile } \\
\text { organic } \\
\text { compound } \\
\text { expl osion in } \\
\text { container with } \\
\text { resul tant fire. }\end{array}$ & $\begin{array}{l}\text { Potential unacceptable dose to } \\
\text { maximum onsite receptor and } \\
\text { exposure to occupational } \\
\text { Horker. Potential injury or } \\
\text { fatality to occupational } \\
\text { Horker. }\end{array}$ & $\begin{array}{l}\text { 1. Container has a vent clip or HEPA } \\
\text { filter to vent internal gas pressure } \\
\text { 2. Packaging requirements to minimize } \\
\text { volatile organic liquids } \\
\text { 3. HEPA filtered ventilation system } \\
\text { with negative pressure }\end{array}$ & Unt ikely & I & onc & No \\
\hline Criticality & $\begin{array}{l}\text { Criticality in } \\
\text { container(s) }\end{array}$ & $\begin{array}{l}\text { Potential unacceptable dose to } \\
\text { maximum onsite receptor and } \\
\text { exposure to occupat ional } \\
\text { worker. Potent ial injury or } \\
\text { fatality to occupational } \\
\text { worker. }\end{array}$ & $\begin{array}{l}\text { 1. Packaging requirements limit the } \\
\text { amount of fissile material present } \\
\text { 2. Each drum may be assayed to } \\
\text { independently check the amount of } \\
\text { fissile materials } \\
\text { 3. } 2 \text { Iier stacking limit }\end{array}$ & Incredible & I & NOC & No \\
\hline
\end{tabular}


Table 3-1. Transuranic Waste Storage and Assay Facility Hazard Analysis. (4 sheets)

\begin{tabular}{|c|c|c|c|c|c|c|c|}
\hline $\begin{array}{l}\text { Accident } \\
\text { group }\end{array}$ & $\begin{array}{l}\text { Accident } \\
\text { scenarios }\end{array}$ & Target/potential consequences & Preventative/mitigating features & Probability(a) & Severity ${ }^{(b)}$ & Rank & $\begin{array}{l}\text { Scenario } \\
\text { selected for } \\
\text { full analysis? }\end{array}$ \\
\hline \multirow[t]{7}{*}{$\begin{array}{l}\text { External } \\
\text { events and } \\
\text { natural } \\
\text { phenomena }\end{array}$} & $\begin{array}{l}\text { Seismic event } \\
(0.12 \mathrm{~g})\end{array}$ & $\begin{array}{l}\text { Potential structural failure, } \\
\text { and or fallen drums, resulting } \\
\text { in rupture of drums: } \\
\text { Potential unacceptable dose to } \\
\text { maximm onsite receptor and } \\
\text { exposure to occupational } \\
\text { worker. Potential injury or } \\
\text { fatality to occupational } \\
\text { worker. }\end{array}$ & $\begin{array}{l}\text { 1. Building structure designed to } \\
\text { withstand a seismic event (0.12g) to } \\
\text { preclude structure falling on } \\
\text { containers and rupturing } \\
\text { 2. } 2 \text { tier stacking limit precludes } \\
\text { containers from rupturing. }\end{array}$ & Untikely & II & OC & Yes \\
\hline & $\begin{array}{l}\text { Seismic event } \\
\text { causes falling } \\
\text { electrical } \\
\text { conduit to } \\
\text { initiate drum } \\
\text { fire }\end{array}$ & $\begin{array}{l}\text { Same as drum fire accident } \\
\text { scenario }\end{array}$ & Same as drum fire accident scenario & $\begin{array}{l}\text { Extremety } \\
\text { Unt ikely }\end{array}$ & I & NOC & No \\
\hline & $\begin{array}{l}\text { High wind event } \\
(70 \mathrm{mph}) \\
(113 \mathrm{~km} / \mathrm{hr})\end{array}$ & $\begin{array}{l}\text { Potential structural failure: } \\
\text { Potential unacceptable dose to } \\
\text { maximum onsite receptor and } \\
\text { exposure to occupational } \\
\text { worker, Potential injury or } \\
\text { fatality to occupational } \\
\text { worker. }\end{array}$ & $\begin{array}{l}\text { 1. Building structure designed to } \\
\text { withstand a high wind event } \\
\text { (150 mi/hr) (241 km/hr) }\end{array}$ & $\begin{array}{l}\text { Extremely } \\
\text { unl ikely }\end{array}$ & IV & NOC & No \\
\hline & $\begin{array}{l}\text { Wind driven } \\
\text { missile impacts } \\
\text { container }\end{array}$ & $\begin{array}{l}\text { Potential structural failure: } \\
\text { Potential unacceptable dose to } \\
\text { maximum onsite receptor and } \\
\text { exposure to occupational } \\
\text { worker. Potential injury or } \\
\text { fatality to occupational } \\
\text { worker. }\end{array}$ & $\begin{array}{l}\text { 1. Building structure designed to } \\
\text { withstand wind missiles } \\
\text { 2. Packaging requirements for double } \\
\text { conf inement }\end{array}$ & $\begin{array}{l}\text { Extremely } \\
\text { unlikely }\end{array}$ & IV & NOC & No \\
\hline & Flooding & $\cdots$ & -- & Incredible & -- & NOC & No \\
\hline & fornado event & -- & $-\cdot$ & Incredible & $\cdots$ & NOC & No \\
\hline & $\begin{array}{l}\text { Excessive } \\
\text { snow/ash } \\
\text { loading eyent } \\
\left(20 \mathrm{lb} / \mathrm{ft}^{2}\right. \\
\left(47.6 \mathrm{~kg} / \mathrm{m}^{2}\right)\end{array}$ & $\begin{array}{l}\text { Potential structural failure: } \\
\text { Potential unacceptable dose to } \\
\text { maximum onsite receptor and } \\
\text { exposure to occupational } \\
\text { worker, Potential injury or } \\
\text { fatality to occupational } \\
\text { worker. }\end{array}$ & 1. Building structure & $\begin{array}{l}\text { Extremely } \\
\text { unlikely }\end{array}$ & IV & NOC & No \\
\hline
\end{tabular}


portions of TRUSAF may reside very close to the drainage basin boundary, no flooding is anticipated from this scenario. Credible flooding from the Columbia or Yakima Rivers would not impact TRUSAF.

- Criticality - a criticality event was not selected for further analysis because it is judged to be an incredible event at TRUSAF ( $i . e$. , a frequency of less than $1 \times 10^{-6}$ ). No postulated accident scenario has been identified that would release container contents, such that sufficient mass to support criticality would occur. The key factors that reduce the probability of a criticality to an incredible level are (1) limits on the form and quantity of fissile material, (2) type of storage container, and (3) spacing as specified by criticality prevention specification. The plutonium content of the containers entering the storage building may be independently checked (i.e., separate from the waste generator) to ensure compliance to specifications. 
Figure 3-1. Four-by-Four Probability and Consequence-Ranking Matrix.

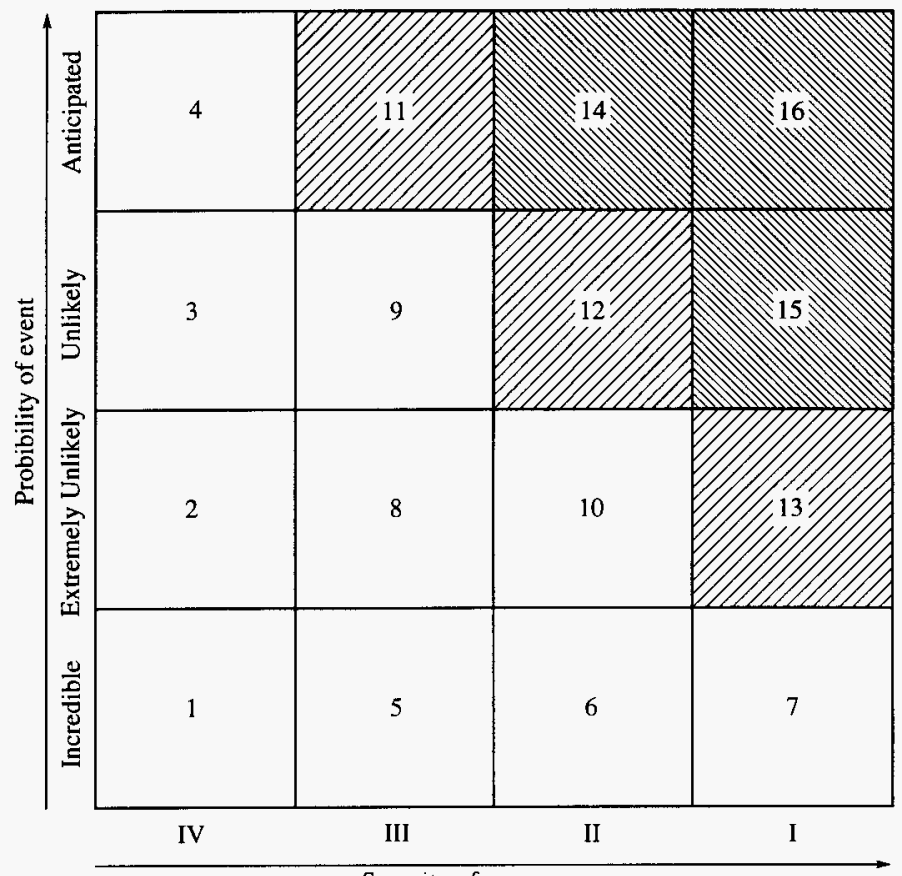

Severity of consequences

Combinations of conclusions from risk analysis that identify situations of major concern

Combinations that identify situations of concern

Ch1-6005-041-050804 
Table 3-2. Qualitative Accident Severity Levels.

\begin{tabular}{|c|l|}
\hline Severity & \multicolumn{1}{|c|}{ Description } \\
\hline IV & $\begin{array}{l}\text { Will not result in injury, occupational illness, or exposure onsite } \\
\text { or offsite, or result in a significant impact on the environment. }\end{array}$ \\
\hline III & $\begin{array}{l}\text { May cause minor injury or minor occupational illness onsite, or } \\
\text { exposure of onsite individuals to radiation below annual limits, } \\
\text { negligible impact offsite, or minor impact on the environment. }\end{array}$ \\
\hline II & $\begin{array}{l}\text { May cause severe injuries or severe occupational illness onsite, } \\
\text { exposure to onsite individuals in excess of annual limits, major } \\
\text { damage to a facility/operation, minor illness or injury offsite, } \\
\text { exposure to offsite individuals to radiation below annual limits, } \\
\text { or major impact on the environment. }\end{array}$ \\
\hline I & $\begin{array}{l}\text { May cause deaths onsite or loss of the facility/operation, major } \\
\text { injuries or illness offsite, radiation exposure to offsite } \\
\text { individuals in excess of annual limits, or severe impact on the } \\
\text { environment. }\end{array}$ \\
\hline
\end{tabular}

Table 3-3. Frequency Ranges.

\begin{tabular}{|l|c|l|}
\hline $\begin{array}{c}\text { Expected } \\
\text { frequency }\end{array}$ & $\begin{array}{l}\text { Frequency of } \\
\text { occurrence } \\
\text { (per year) }\end{array}$ & \multicolumn{1}{|c|}{ Description } \\
\hline Anticipated & $1 \geq p \geq E-02$ & $\begin{array}{l}\text { An abnormal event that is expected to occur } \\
\text { once or more during the lifet ime of the } \\
\text { facility (incidents that commonly occur). }\end{array}$ \\
\hline Unlikely & $E-02 \geq p \geq E-04$ & $\begin{array}{l}\text { Accidents that are not anticipated to occur } \\
\text { during the lifetime of the facility. }\end{array}$ \\
\hline $\begin{array}{l}\text { Extremely } \\
\text { unlikely }\end{array}$ & $E-02 \geq p \geq E-06$ & $\begin{array}{l}\text { Extremely low probability conditions that } \\
\text { are not expected during the plant lifetime, } \\
\text { but that represent extreme or limiting } \\
\text { cases of faults identified as possible. } \\
\text { This class includes evaluation basis } \\
\text { accidents. }\end{array}$ \\
\hline Incredible & $E-06 \geq p$ & $\begin{array}{l}\text { Accidents for which no credible scenario } \\
\text { can be identified. }\end{array}$ \\
\hline
\end{tabular}


The 224-T Building must comply with the criticality safety limits shown in Tables 3-4, 3-5, and 3-6 (WHC 1989).

Table 3-4. Process and Equipment Limits.

Drums of TRU waste are transferred to the 224-T Building from fissionable material facilities for assay, RTR, and storage. An initial assay may be performed before transfer to the 224-T Building (in the case of retrieved drums, the assay checks the plutonium content of the drum as documented on the waste drum storage record).

The 224-T Building is approved for handling and storing painted or galvanized 55 gal. DOT Specification $17 \mathrm{C}$ and $17 \mathrm{H}$ drums, and UN1A2 drums.

The fissionable materials have been placed in containers. Waste containers are not opened at the 224-T Building.

DOT $=$ U.S. Department of Transportation.

Table 3-5. Storage Array Limits.

\begin{tabular}{|l|c|}
\hline \multicolumn{1}{|c|}{ Limited inventory } & Maximum amount \\
\hline $\begin{array}{l}\text { Maximum fissile material content with the fissile material } \\
\text { occupying 20\% or more of the drum volume }\end{array}$ & $200 \mathrm{~g}$ \\
\hline $\begin{array}{l}\text { Maximum fissile material content with the fissile material } \\
\text { occupying less than 20\% of the drum volume }\end{array}$ & $100 \mathrm{~g}$ \\
\hline Maximum number of layers (tiers) & 2 tiers \\
\hline Maximum array size & Unlimited \\
\hline
\end{tabular}

Table 3-6. Storage Array Limits for Assayed Drums $>200 \mathrm{~g}$.

\begin{tabular}{|l|c|}
\hline \multicolumn{1}{|c|}{ Limited inventory } & Maximum amount \\
\hline Fissile content per drum & $400 \mathrm{~g}$ \\
\hline Number of layers (tiers) & $1 \mathrm{tier}$ \\
\hline Array size (L $\times \mathrm{W} \times \mathrm{H}$ of drums) & $10 \times 10 \times 1$ \\
\hline Separation from other drums & $3 \mathrm{ft}$ \\
\hline
\end{tabular}

TRU content of containers entering the storage building may be checked for compliance to the criticality prevention specifications. Nondestructive methods employing neutron sensitive instruments are used, when necessary, to confirm the fissile content. These measurements and other controls (e.g., formal audits) are used to ensure compliance with the storage regulations. The measurements and other controls referred to here in the text are part of the Criticality Program, which will be included in the IOSRs as Administrative Contro\} 5.3, Nuclear Criticality Safety. 


\subsubsection{Accident Analysis}

The following sections provide quantitative analyses of the bounding accidents selected from the hazards analysis. Quantitative source term calculations require that the facility inventory be characterized. Appendix A provides a statistical evaluation of the TRU and MFP content derived from information in the Solid Waste Information Tracking System (SWITS), (WHC 1995d) for drums currently stored in TRUSAF and drums associated with the Pilot Retrieval Project. The TRU is assumed to be a mixture of plutonium isotopes defined as $12 \%{ }^{240} \mathrm{Pu}$ aged 20 years in this analys is (Table $3-7$ ). The corresponding specific activity is $1.29 \mathrm{Ci} / \mathrm{g}$. The hazardous material content of the current drum inventory is identified and quantified in Table 3-8. Radiological consequences are addressed in the accident analyses in Sections 3.1.4.1 through 3.1.4.5. A bounding analysis for hazardous material releases is provided in Section 3.1.3.6.

The T Plant Complex is the only normally occupied facilities in close proximity to TRUSAF. However, the TRUSAF was once part of the T Plant Complex and is located less than $100 \mathrm{~m}$ (109 yd) from other buildings still in the $T$ Plant Complex.

Because of this close proximity, T Plant and TRUSAF share the same dose consequence receptor distances for analytical purposes. The maximum onsite receptor for both TRUSAF and T Plant which is the closest normally occupied facility not in the TRUSAF/T Plant Emergency Planning horizon, is located $0.5 \mathrm{~km}(500 \mathrm{~m})$ SSE at the MO-279 Building.

Table 3-7. Nominal 12\% ${ }^{240} \mathrm{Pu}$, Aged Twenty Years (WHC 1993).

\begin{tabular}{|c|c|c|c|c|c|}
\hline & $A$ & B & C & D & E \\
\hline Isotope & Wt\% & Specific activity (Ci/g) & Ci/g of TRU & $\begin{array}{c}\text { Correction } \\
\text { factor }\end{array}$ & PE-Ci/g of TRU \\
\hline $238 \mathrm{Pu}$ & 0.08 & $1.71 \mathrm{E}+01$ & $1.37 \mathrm{E}-02$ & $1 / 1.1$ & $1.24 \mathrm{E}-02$ \\
\hline $239 \mathrm{Pu}$ & 83.95 & $6.20 \mathrm{E}-02$ & $5.20 \mathrm{E}-02$ & 1 & $5.20 \mathrm{E}-02$ \\
\hline $240 \mathrm{Pu}$ & 12.97 & $2.27 \mathrm{E}-01$ & $2.94 \mathrm{E}-02$ & 1 & $2.94 \mathrm{E}-02$ \\
\hline $241_{\mathrm{PU}}$ & 1.10 & $1.03 \mathrm{E}+02$ & $1.13 \mathrm{E}+00$ & $1 / 52$ & $2.17 \mathrm{E}-02$ \\
\hline $242 \mathrm{Pu}$ & 0.03 & $3.93 \mathrm{E}-03$ & $1.17 \mathrm{E}-06$ & $1 / 1.1$ & $1.06 \mathrm{E}-02$ \\
\hline $241_{\mathrm{Am}}$ & 1.75 & $3.42 \mathrm{E}+00$ & $5.99 \mathrm{E}-02$ & 1 & $5.99 \mathrm{E}-06$ \\
\hline & & & $1.29 \mathrm{E}+00$ & & $1.75 \mathrm{E}-01$ \\
\hline
\end{tabular}

Column $C=$ Column A $\times$ Column B; Column E = Column C $\times$ column D.

$b$ The dividend in the factors in Cotymn $D$ is the ratio of the dose conversion factor for the isotope to the dose conversion factor for $239 \mathrm{PU}$, WHC-EP-0063, Hanford Site Sol id Waste Acceptance Criteria. 
Table 3-8. Hazardous Characteristics for Drums at Transuranic Waste Storage and Assay Facility (as of 4/94).

\begin{tabular}{|c|c|c|c|c|c|}
\hline Hazardous waste & $\begin{array}{c}\# \text { of } \\
\text { containers }\end{array}$ & $\begin{array}{l}\operatorname{Maximum} \\
(\mathrm{kg})\end{array}$ & $\underset{(\mathrm{kg})}{\operatorname{Minimum}}$ & $\begin{array}{l}\text { Average } \\
\text { (kg) }\end{array}$ & $\begin{array}{l}\text { Facility } \\
\text { total (kg) }\end{array}$ \\
\hline Acid & 1 & 0.1400 & 0.1400 & 0.1400 & 0.1400 \\
\hline Aluminum nitrate monohydrate & 1 & 3.9000 & 3.9000 & 3.900 & 3.9000 \\
\hline Asbestos & 6 & 27.0022 & 0.5000 & 7.5673 & 45.4038 \\
\hline Barium & 21 & 0.8001 & 0.0000 & 0.0801 & 1.6821 \\
\hline Cactmium & 25 & 89.9923 & 0.0000 & 3.7794 & 94.4850 \\
\hline Calcium chtorofluorophosphate & 3 & 0.0100 & 0.0010 & 0.0052 & 0.0156 \\
\hline Calcium hydroxide & 1 & 0.0567 & 0.0567 & 0.0567 & 0.0567 \\
\hline Carbon tetrachloride & 16 & 15.3994 & 0.0100 & 5.5744 & 89.1910 \\
\hline Caustic & 1 & 0.1500 & 0.1500 & 0.1500 & 0.1500 \\
\hline Chromium & 59 & 0.3600 & 0.0000 & 0.1961 & 11.5699 \\
\hline Lead & 207 & 123.3765 & 0.0250 & 17.9949 & 3724.9443 \\
\hline Lead acid & 4 & 0.2000 & 0.0100 & 0.0625 & 0.2500 \\
\hline Lead chromate & 20 & 7.9700 & 0.0100 & 1.1438 & 22.8760 \\
\hline Lead chromate oxide & 2 & 1.5200 & 0.0200 & 0.7700 & 1.5400 \\
\hline Leed chromate, chlorin. paraffin & 2 & 0.2000 & 0.0200 & 0.1100 & 0.2200 \\
\hline Lead chromates & 1 & 0.0500 & 0.0500 & 0.0500 & 0.0500 \\
\hline Lead shielding & 1 & 50.5000 & 50.5000 & 50.5000 & 50.5000 \\
\hline Mercury & 24 & 0.5000 & 0.0000 & 0.0472 & 1.1328 \\
\hline Nitric acid & 79 & 0.0300 & 0.0000 & 0.0097 & 0.7663 \\
\hline Phthal ic acid benzyl butyl ester & 1 & 0.0005 & 0.0005 & 0.0005 & 0.0005 \\
\hline Phthal ic acid bis(2-ethylhexyl) ester & 1 & 0.0074 & 0.0074 & 0.0074 & 0.0074 \\
\hline Potassium hydroxide & 6 & 0.5000 & 0.0010 & 0.1068 & 0.6408 \\
\hline Selenium & 57 & 0.0400 & 0.0005 & 0.0193 & 1.1001 \\
\hline Sodium & 1 & 0.1250 & 0.1250 & 0.1250 & 0.1250 \\
\hline Sodium hydroxide & 102 & 0.5500 & 0.0200 & 0.1889 & 19.2678 \\
\hline Sulfuric acid & 2 & 1.5000 & 0.0200 & 0.7600 & 1.5200 \\
\hline Tributyl phosphate & 8 & 5.9012 & 4.0002 & 5.4260 & 43.4080 \\
\hline
\end{tabular}

Roads and other structures separate from the TRUSAF and T P1 ant that are located within $500 \mathrm{~m}$ (547 yd) are not normally occupied facilities and do not affect the location of the onsite receptor. TRUSAF and T Plant are parts of the Solid Waste Disposal Organization and have appropriately coordinated building emergency plans and other programs to ensure safe operation of the facilities and worker protection. 


\subsubsection{Forklift Accident.}

3.1.4.1.1 Scenario. Hand-operated, walk-behind forklifts are used to move drums to the nondestructive assay areas. Hand-operated fork 1 ifts also are used to place the drums in storage. It is assumed for this analysis that, because of an operator error, a forklift impacts a drum storage module. The speed of the forklift is conservatively assumed to be sufficient for the tines to puncture two drums. The impact of the forklift hitting the drum module topples drums from the second tier. No breach of containment is postulated because the drums fall $<1.2 \mathrm{~m}(4 \mathrm{ft})$.

3.1.4.1.2 Source Term. The inventory at risk is determined, in accordance with the approach outlined in Appendix $A$. However, the accident analysis assumed that both drums contain $400 \mathrm{~g}$. It is therefore,

$$
\text { Inventory }_{\text {risk }}=[400 \mathrm{~g}+400 \mathrm{~g}] \times\left(\frac{1.29 \mathrm{Ci}}{\mathrm{g} \text { TRU }}\right)=1032 \mathrm{Ci}
$$

The bases for the postulated releases and their associated airborne release fractions (ARF) and respirable fractions (RF) are taken from DOE-HDBK-3010-94, Airborne Release Fractions/Rates, and Respirable Fractions for Nonreactor Nuclear Facilities. This bases, summarized in DOE-HDBK-3010-94, are a DOE effort to provide reasonable factors for estimating the radiological source terms in deterministic analyses of upper-bound, worst-case accident scenarios postulated for nonreactor facilities. The factors in DOE-HDBK-3010-94 are based on experimental data.

For the situation where the material is packaged in a reasonably robust container (e.g., drum) that fails, as a result of impact, the bounding ARF and RF assigned in DOE-HDBK-3010-94, Section 5.2.3.2, are $1 \times 10^{-3}$ and 0.1 . These values are the same as that assigned to suspension of powder in a can, as a result of debris impact (DOE-HDBK-3010-94, Section 4.4.3.3.2), which bounds this phenomena. Therefore, the bounding overall airborne fraction that is respirable is $1 \times 10^{-4}$.

To determine the amount of material potentially exiting the 208-L (55-gal) drum during a mechanical release, as a result of an accident scenario including rupture, crush, or fall, the leak path factor described in DOE-HDBK-0013-93 is used. The material is conservatively considered to exist in powder form; however, as a result of the metal drum and the waste being wrapped in layers of plastic, various levels of confinement are provided depending upon the accident scenario. A series of 17-C 208-L (55-gal) drum drop tests onto hard, unyielding surfaces, documented in Analysis, Scale Modeling, and Full-Scale Tests of Low-Level Nuclear-Waste-Drum Response to Accident Environments, SAND80-2517 (Huerta, et a1. 1983), revealed that new drums with 90-mil plastic liners could sustain substantially higher drop heights than specified for DOT Type A containers before release of the drum 1 id occurred. With drum weights of $\approx 318 \mathrm{~kg}(700 \mathrm{lb})$, a drop height of $13 \mathrm{~m}$ $(44 \mathrm{ft})$ was required before the drum lids were breached. In such cases, no contents of the drums were ejected externally to the $90 \mathrm{mil}$ liners; therefore, for drop heights of $1.2 \mathrm{~m}(4 \mathrm{ft})$ or less, no breach of drums is assumed to 
take place. For drops from heights greater than $1.2 \mathrm{~m}(4 \mathrm{ft})$, a LPF of 0.01 is estimated. This value for the LPF is the fraction obtained when the area of the opening resulting from lid distortion is divided by the surface area of the drum. This leak path factor is then multiplied by the ARF and RF of $1 \times 10^{-3}$ and 0.1 to yield an overall release fraction that is respirable of 1 $\times 10^{-3} \times 0.1 \times 0.01=1 \times 10^{-6}$. For a drum puncture from a fork 1 ift tine, a leak path factor of 0.01 is considered because of the relatively small hole a forkl ift tine would cause. The respirable airborne activity is therefore,

$$
\begin{aligned}
\text { Activity }_{\text {airborne }} & =(1032) \times(0.01) \times\left(1 \times 10^{-3}\right) \times(0.1) \\
& =1.03 \times 10^{-3} \mathrm{Ci} .
\end{aligned}
$$

The consequences of the unmitigated and filtered releases are provided to establish likely consequences for the preceding accidents presented and for the unmitigated consequence if the filters were breached to determine the safety significance of the ventilation system. Drum storage areas in TRUSAF are provided with a single stage of HEPA filtration (Section 2.4). The HEPA filter ventilation system is comprised of roughing filters, HEPA filters, supply fans, exhaust fans, differential pressure indicators, and ductwork. This HEPA filter system is tested when installed to verify a filtering efficiency of at least $99.95 \%$, in accordance with WHC-CM-5-36, Chapter 7-5, "Environmental Compliance Manual." The system is tested on an annual basis thereafter. Taking credit for this system, the source term is.

$$
\text { Source term }=\left(1.03 \times 10^{-3} \mathrm{Ci}\right) \times(0.0005)=5.2 \times 10^{-7} \mathrm{Ci} \text {. }
$$

3.1.4.1.3 Consequences. Radiological consequences of airborne releases of radioactive materials are calculated using the following equation.

$$
\text { Dose }\left(\text { rem) }=S T(C i) \times \frac{X}{Q}\left(s / m^{3}\right) \times C(r e m / C i) \times R\left(m^{3} / s\right)\right.
$$

where

$$
\begin{aligned}
S T & =\text { quantity plutonium released per source term } \\
X / Q & =\text { atmospheric dispersion coefficient } \\
C & =\text { plutonium dose conversion factor } \\
\mathrm{R} & =\text { breathing rate. }
\end{aligned}
$$

Applicable atmospheric dispersion, dose conversion, and breathing rate values are presented in Appendix B. Atmospheric dispersion coefficients $(X / Q)$ were calculated for the maximally exposed onsite individual $500 \mathrm{~m}$ south-southeast and the maximally exposed offsite individual $13,110 \mathrm{~m}$ west or $22,570 \mathrm{~m}$ east, depending on the scenario, of the point of release. Two sets of $x / Q$ values, a ground level release with building wake and a buoyant plume rise with building wake and plume trapping, were calculated (Appendix B). 
Dose conversion factors for TRU isotopes were developed based on a plutonium isotopic distribution of $12 \%{ }^{240} \mathrm{Pu}$ aged twenty years. TRU dose conversion factors are presented for insoluble plutonium in the fire/explosion scenarios and for soluble plutonium in all other scenarios. MFP dose conversion factors demonstrated that dose contribution is insignificant $(<0.01 \%$ ) (Appendix $B$ ). Accordingly, radiological consequences are based solely on the TRU source term.

A breathing rate, referenced from the Manual of Anatomical, Physiological, and Metabolic Characteristics (ICRP 1975), of $3.3 \times 10^{-4} \mathrm{~m}^{3} / \mathrm{s}$ is applied to both onsite and offsite receptors. It is conservatively assumed that the receptor is located at the center line of the plume for the duration of plume passage.

Applying the above equation and the evaluation method (Appendix $B$ ), the onsite and offsite radiological consequences of a forklift accident resulting in a source term of $1.03 \times 10^{-3} \mathrm{Ci}$ are shown in Table 3-9. These consequences are considered unmitigated and provided to show that no credit for HEPA filtration is necessary to meet risk criteria.

Table 3-9. Dose Consequences of Forklift Accident without HighEfficiency Particulate Air Filtration.

\begin{tabular}{|l|c|}
\hline \multicolumn{1}{|c|}{ Location } & Dose (rem) \\
\hline Onsite EDE & $1.2 \mathrm{E}-02$ \\
\hline Offsite EDE & $3.0 \mathrm{E}-04$ \\
\hline
\end{tabular}

$E D E=$ effective dose equivalent.

For the onsite effective dose equivalent (EDE) dose

$$
\begin{aligned}
& \text { ST }=1.03 \times 10^{-3} \mathrm{Ci} \\
& (x / Q)=5.94 \times 10^{-4} \mathrm{~s} / \mathrm{m}^{3} \text { (Table B-1, Onsite Ground Level Release) } \\
& \left.C=6.0 \times 10^{7}(\mathrm{rem} / \mathrm{Ci}) \text { (Table } \mathrm{B}-2, \mathrm{Pu}, \mathrm{EDE}\right) \\
& R=3.3 \times 10^{-4}\left(\mathrm{~m}^{3} / \mathrm{s}\right) \text { (ICRP 1975) } \\
& \text { Dose }(\mathrm{rem})=\mathrm{ST}(\mathrm{C} i) \times\left(\frac{x}{Q}\right)\left(\mathrm{s} / \mathrm{m}^{3}\right) \times C(\mathrm{rem} / \mathrm{C} \mathrm{i}) \times \mathrm{R}\left(\mathrm{m}^{3} / \mathrm{s}\right)= \\
& \left(1.03 \times 10^{-3} \mathrm{Ci}\right) \times\left(5.94 \times 10^{-4} \mathrm{~s} / \mathrm{m}^{3}\right) \times\left(6.0 \times 10^{7} \mathrm{rem} / \mathrm{Ci}\right) \times \\
& \left(3.3 \times 10^{-4} \mathrm{~m}^{3} / \mathrm{s}\right)=1.21 \times 10^{-2} \mathrm{rem} .
\end{aligned}
$$


For the offsite EDE dose

$$
\begin{aligned}
& \text { ST }=1.03 \times 10^{-3} \mathrm{Ci} \\
& (x / Q)=1.48 \times 10^{-5} \mathrm{~s} / \mathrm{m}^{3} \text { (Table B-1, Offsite Ground Level Release) } \\
& C=6.0 \times 10^{7}(\mathrm{rem} / \mathrm{Ci})(\mathrm{Table} B-2, \mathrm{Pu}, \mathrm{EDE}) \\
& R=3.3 \times 10^{-4}\left(\mathrm{~m}^{3} / \mathrm{s}\right) \text { (ICRP 1975) } \\
& \text { Dose }(\mathrm{rem})=\mathrm{ST}(\mathrm{Ci}) \times\left[\frac{X}{Q}\right]\left(\mathrm{s} / \mathrm{m}^{3}\right) \times C(\mathrm{rem} / \mathrm{C} i) \times R\left(\mathrm{~m}^{3} / \mathrm{s}\right)= \\
& \left(1.03 \times 10^{-3} \mathrm{Ci}\right) \times\left(1.48 \times 10^{-5} \mathrm{~s} / \mathrm{m}^{3}\right) \times\left(6.0 \times 10^{7} \mathrm{rem} / \mathrm{Ci}\right) \times \\
& \left(3.3 \times 10^{-4} \mathrm{~m}^{3} / \mathrm{s}\right)=3.02 \times 10^{-4} \mathrm{rem} .
\end{aligned}
$$

3.1.4.1.4 Frequency. A forkl ift accident at TRUSAF is an anticipated event. An anticipated event has a frequency of $1 / \mathrm{yr}$ to $1 \times 10^{-2} / \mathrm{yr}$ for onsite and offsite risk evaluation.

\begin{tabular}{|c|c|c|}
\hline \multirow{2}{*}{ Accident release } & Onsite dose (rem) & Offsite dose (rem) \\
\hline & EDE & EDE \\
\hline $5.2 \mathrm{E}-07 \mathrm{Ci}$ source term ${ }^{(a)}$ & $6.1 E-06$ & $1.5 \mathrm{E}-07$ \\
\hline $1.03 \mathrm{E}-03 \mathrm{Ci}$ source term $^{(\mathrm{b})}$ & $1.2 E-02$ & $3.0 \mathrm{E}-04$ \\
\hline Dose guideline ${ }^{(c)}$ & 1 & $1.0 E-02$ \\
\hline
\end{tabular}

3.1.4.1.5 Conclusions. The upper boundary of the frequency estimate is used (i.e., l/yr). The risk-acceptance guidelines are met without credit taken for HEPA filtration (Table 3-10). The onsite and offsite radiological consequences, given a source term of $5.2 \times 10^{-7} \mathrm{Ci}$ (i.e., credit for HEPA filtration), are also shown in Table 3-10.

Table 3-10. Forklift Accident Comparison.

(a) HEPA-filtered release.

(b) Nonfiltered release.

(c) From WHC 1995a for a $1 /$ yr event.

$E D E$ = effective dose equivalent. 


\subsubsection{Drum Fire.}

3.1.4.2.1 Scenario. Fires within TRUSAF could be initiated internally or externally to the waste drums. Internal initiation (i.e., spontaneous combustion) could be the result of exothermic reactions between incompatible chemicals or from oxidation of pyrophoric materials. Sources of external initiation include electrical shorts and maintenance activities (e.g., welding). An internally initiated fire has been selected for analysis in this document. Such a fire would directly involve radioactive/hazardous materials, whereas an externally-initiated fire would need to be of sufficient magnitude and duration to spread to the waste drums. Such a fire is judged to be extremely unlikely, if not incredible, when the concrete facility walls, floors, and ceilings, and minimal combustible loadings outside the drums, ensured by procedure and inspection, are considered.

The assumed internal fire is initiated by either an exothermic reaction between incompatible chemicals or oxidation of pyrophoric materials. Sufficient oxygen consumes all of the combustible materials in the drum. Heat and pressure generated by the fire fails the 1 id seal and allows radioactive materiais to escape into the storage area. No credit is given to manual or automatic fire suppressions systems. The heat and smoke generated by a single drum fire is assumed to be insufficient to impact the HEPA filters.

Drum fire propagation is an important safety issue across the DOE Complex and is the subject of many studies and tests. Recent fire propagation testing conducted at the Southwest Research Institute in San Antonio Texas and noted in Analytic and Experimental Evaluation of Solid Waste Drum Fire Performance, WHC-SD-WM-TRP-233, Rev. 0 (WHC 1995c), indicated that no fire propagation occurs between drums, except when the drums are directly within the flames of an extended hydrocarbon fuel fire or where placed on combustible pallets adjacent to a hydrocarbon fuel fire. For this analysis, it will be assumed that the fire does not propagate (i.e., that the fire is limited to a single drum).

3.1.4.2.2 Source Term. The TRU inventory at risk for single drum accidents is $400 \mathrm{~g}$. Converting to activity, the inventory at risk is:

$$
\text { Inventory }_{\text {risk }}=(400 \mathrm{~g}) \times\left(\frac{1.29 \mathrm{Ci}}{\mathrm{g} \mathrm{TRU}}\right)=516 \mathrm{Ci} .
$$

The SWITS (WHC 1995d) data was used to determine the percentage of TRU contaminated combustible and noncombustible materials in TRU waste drums. The TRU material is assumed to be distributed evenly throughout the combustibles and noncombustibles within the drums. It is estimated that $84 \%$ of the TRU contaminated material in a drum is combustible and $16 \%$ of TRU contaminated material is noncombustible. Therefore, $84 \%$ of the TRU material is released directly from combustion of the combustible material in a drum and $16 \%$ of the TRU is released because of heating of the noncombustible materials involved in a fire. 
For surface-contaminated combustible solids, DOE-HDBK-3010-94 categorizes the ARF and RF resulting from thermal stress into three categories: packaged waste (2) uncontained, combustible materials, and (3) contaminated noncombustible solids. The ARF's and RF's for the lst and 3rd categories, i.e. packaged waste and contaminated noncombustible solids, are applicable to this analysis for a drum fire. Packaged waste is appropriate for drummed waste because a plastic liner is present in the drum which after filling is wrapped close and tied off. Further, the material is often contained in individual plastic packets. ARF's and RF's for noncombustible solids cover the contaminated solid articles in the waste such as tools, pipe and scrap metal. The ARF and RF for uncontained waste is not applicable to a drum fire but is used for drum explosions to analyze the release due to burning of material dispersed by any explosion. All three categories may result from accident scenarios and the experimental bases for these ARF and RF, as reported in DOE-HDBK-3010-94 are further examined.

For packaged waste, DOE-HDBK-3010-94 recommends a bounding ARF and RF of $5 \times 10^{-4}$ and 1.0 and a median ARF and RF of $8 \times 10^{-5}$ and 1.0 . The packaged waste values are based upon a set of 11 experiments in which large cardboard boxes containing mixed waste (paper, rags, tape, plastic, cardboard, and oil) contaminated with uranium dioxide powder, uranyl nitrate liquid, and air-dried uranyl nitrate were burned. The recommended ARF is $5 \times 10^{-4}$ and the recommended RF is 1.0 (DOE-HDBK-3010-94). The activity resulting from combustible solids is therefore,

$$
\begin{aligned}
\text { Activity }_{\text {combustible }}= & (516 \mathrm{Ci}) \times(84 \%) \times\left(5 \times 10^{-4}\right) \times(1.0) \\
= & 2.16 \times 10^{-1} \mathrm{Ci} .
\end{aligned}
$$

The ARF for contaminated noncombustible solids as packaged waste is based on reasoned judgement that suspension of surface contamination under thermal stress is bounded by values for suspension of reactive powders under thermal stress in a flowing airstream. For thermal stress of contaminated, noncombustible solids, a bounding ARF and $R F$ value of $6 \times 10^{-3}$ and 0.01 is used and results in an overall RF of $6 \times 10^{-5}$. The release resulting from heating noncombustible solids is therefore,

$$
\begin{aligned}
& \text { Activity }{ }_{\text {noncombustible }}=(516 \mathrm{Ci}) \times(16 \%) \times\left(6 \times 10^{-5}\right) \\
& =4.95 \times 10^{-3} \mathrm{Ci} \text {. }
\end{aligned}
$$

The respirable activity airborne within TRUSAF is therefore,

$$
\begin{aligned}
\text { Activity }_{\text {airborne }}= & \left(2.16 \times 10^{-1} \mathrm{Ci}\right)+\left(4.95 \times 10^{-3} \mathrm{Ci}\right) \\
= & 2.2 \times 10^{-1} \mathrm{Ci} .
\end{aligned}
$$

TRUSAF drum storage areas are provided with a single stage of HEPA 
filtration (Section 2.4). This HEPA filter system is tested when installed to verify a filtering efficiency of at least $99.95 \%$. The system is tested on an annual basis thereafter. Taking credit for this system, the source term is

$$
\text { Source term }=\left(2.2 \times 10^{-1} \mathrm{Ci}\right) \times(0.0005)=1.1 \times 10^{-4} \mathrm{Ci} \text {. }
$$

3.1.4.2.3 Consequences. The onsite and offsite radiological consequences of a drum fire resulting in a source term of $2.2 \times 10^{-1} \mathrm{Ci}$, using the $X / Q$, insoluble (contaminants are converted by fire to insoluble oxides) dose conversion and breathing rate values (Appendix B), are shown in Table 3-11. These consequences are considered unmitigated and provided to show that no credit for HEPA filtration is necessary to meet the risk criteria.

Table 3-11. Dose Consequences of Drum Fire without High-Efficiency Particulate Air Filtration.

\begin{tabular}{|l|c|}
\hline \multicolumn{1}{|c|}{ Location } & Dose (rem) \\
\hline Onsite EDE & 1.9 \\
\hline Offsite EDE & $4.6 \mathrm{E}-02$ \\
\hline
\end{tabular}

$E D E$ = effective dose equivalent.

Applying the calculation evaluation method (Appendix B) with the consequence values, the onsite and offsite radiological consequences of a drum fire accident resulting in a source term of $2.2 \times 10^{-1} \mathrm{C} i$ are:

For the onsite EDE dose

$$
\begin{aligned}
\text { ST } & =2.2 \times 10^{-1} \mathrm{Ci} \\
(X / Q) & =5.94 \times 10^{-4} \mathrm{~s} / \mathrm{m}^{3} \text { (Table B-1, Onsite Ground Level Release) } \\
C & =4.3 \times 10^{7}(\mathrm{rem} / \mathrm{Ci}) \text { (Table B-2, Pu, EDE) } \\
\mathrm{R} & =3.3 \times 10^{-4}\left(\mathrm{~m}^{3} / \mathrm{s}\right) \text { (ICRP 1975). }
\end{aligned}
$$

$$
\begin{gathered}
\text { Dose }(\text { rem })=S T(C i) \times\left(\frac{x}{Q}\right)\left(\mathrm{s} / \mathrm{m}^{3}\right) \times C(\mathrm{rem} / \mathrm{Ci}) \times R\left(\mathrm{~m}^{3} / \mathrm{s}\right)= \\
\left(2.2 \times 10^{-1} \mathrm{C} i\right) \times\left(5.94 \times 10^{-4} \mathrm{~s} / \mathrm{m}^{3}\right) \times\left(4.3 \times 10^{7} \mathrm{rem} / \mathrm{Ci}\right) \times \\
\left(3.3 \times 10^{-4} \mathrm{~m}^{3} / \mathrm{s}\right)=1.85 \times 10^{0} \mathrm{rem} .
\end{gathered}
$$

For the offsite EDE dose

$$
\begin{array}{ll}
\text { ST } & =2.2 \times 10^{-1} \mathrm{Ci} \\
(X / Q) & =1.48 \times 10^{-5} \mathrm{~s} / \mathrm{m}^{3} \text { (Table B-1, offsite Ground Level Release) } \\
\mathrm{C} & =4.3 \times 10^{7}(\mathrm{rem} / \mathrm{Ci})(\mathrm{Tab} \text { le B-2, Pu, EDE) } \\
\mathrm{R} & =3.3 \times 10^{-4}\left(\mathrm{~m}^{3} / \mathrm{s}\right) \text { (ICRP 1975) }
\end{array}
$$




$$
\begin{gathered}
\text { Dose }(\text { rem })=S T(C i) \times\left(\frac{x}{Q}\right)\left(\mathrm{s} / \mathrm{m}^{3}\right) \times C(\text { rem } / C i) \times R\left(\mathrm{~m}^{3} / \mathrm{s}\right)= \\
\left(2.2 \times 10^{-1} \mathrm{Ci}\right) \times\left(1.48 \times 10^{-5} \mathrm{~s} / \mathrm{m}^{3}\right) \times\left(4.3 \times 10^{7} \mathrm{rem} / \mathrm{Ci}\right) \times \\
\left(3.3 \times 10^{-4} \mathrm{~m}^{3} / \mathrm{s}\right)=4.62 \times 10^{-2} \mathrm{rem} .
\end{gathered}
$$

3.1.4.2.4 Frequency. An internally-initiated drum fire could be the result of exothermic reactions between incompatible chemicals or oxidation of pyrophoric materials. Corrosive, reactive, and ignitable materials require treatment to remove hazardous characteristics (WHC-EP-0063). A11 TRU waste packages that contain hazardous contaminants are also required to meet the waste-acceptance criteria outlined in WHC-EP-0063. Packages shall not contain materials of two or more incompatible hazard classes, the mixture of which would be liable to cause a dangerous evolution of heat or gas, or produce corrosive materials (WHC-EP-0063). Pyrophoric materials are required to be rendered safe by mixing them with chemically stable materials (e.g., concrete or glass) or to be processed to remove their hazardous properties (WHC-EP-0063).

Spontaneous combustion could occur in a drum. Generators of TRU waste are required to certify compliance with TRU Waste Certification Compliance Requirements for Acceptance of Newly Generated, Contact-Handled Waste to be Shipped to the Waste Isolation Pilot Plant, WIPP-D0E-120 (WIPP 1989), by DOE Order 5480.2A, Radioactive Waste Management.

Packaging errors involving incompatible or pyrophoric materials are expected to occur infrequently (i.e., $1 \times 10^{-3}$ to $1 \times 10^{-4} / \mathrm{drum}$ ) given the formality of waste certification programs. The number of drums received from waste generators packaging TRU-contaminated incompatible or pyrophoric materials would need to be known to determine the frequency of spontaneous combustion in a TRUSAF drum. Although this value could perhaps be derived for the existing facility inventory, it is unknown in relation to retrieved drums and future waste shipments. A drum fire is estimated to be an unlikely event for this analysis. An unlikely event has a frequency ranging from $1 \times 10^{-2} / \mathrm{yr}$ to $1 \times 10^{-4} / \mathrm{yr}$. This frequency range is consistent with DOE's operational history. Within this range, it is conceivable that spontaneous combustion would occur more frequently in a retrieval drum versus a newly generated drum based on differences in waste-acceptance criteria and attendant quality assurance measures. A review of spontaneous combustion incidents at DOE facilities in Waste Drum Fire Propagation at the Waste Isolation Pilot Plant, DOE/WIPP-87-005 (DOE 1987), showed that one relevant spontaneous combustion occurred in $1.8 \times 10^{6}$ container-years. Dividing the TRUSAF storage capacity of 1,500 drums by this value yields a frequency of $8.3 \times 10^{-4} / \mathrm{yr}$.

3.1.4.2.5 Conclusions. The upper boundary of the frequency estimate is used ( $\left.i . e ., 1 \times 10^{-2} / y r\right)$. The risk-acceptance guidelines are met without credit taken for HEPA filtration (Table 3-12). The onsite and offsite radiological consequences given a source term of $2.2 \times 10^{-1} \mathrm{Ci}$ (i.e., credit for HEPA filtration) are also shown in Table 3-12. 
As documented in Section 3.1.4.2.1, no fire propagation occurs between drums, except when the drums are directly within the fiames of an extended hydrocarbon fuel fire or where drums are on combustible pallets adjacent to a hydrocarbon fuel fire. The single drum scenario assumes that the installed fire detection/suppression systems are not activated.

Table 3-12. Drum Fire Comparison.

\begin{tabular}{|c|c|c|}
\hline \multirow{2}{*}{ Accident release } & Onsite dose (rem) & Offsite dose (rem) \\
\hline & EDE & EDE \\
\hline $1.1 \mathrm{E}-04 \mathrm{Ci}$ source term ${ }^{(a)}$ & $9.5 E-04$ & $2.3 \mathrm{E}-05$ \\
\hline $2.2 \mathrm{E}-01 \mathrm{Ci}$ source term $^{(b)}$ & 1.9 & $4.6 E-02$ \\
\hline Dose guidel ine ${ }^{(c)}$ & 5 & 0.5 \\
\hline
\end{tabular}

(a) HEPA-filtered release.

(b) Nonfiltered release.

(c) From WHC 1995a, for a $1 \times 10^{-2} / \mathrm{yr}$ event.

$E D E$ = effective dose equivalent.

\subsubsection{Drum Explosion.}

3.1.4.3.1 Scenario. The drum explosion scenario can occur because of a build-up of flammable gas within the void space of a drum. Gases potentially present in TRU drums include hydrogen (generated by the radiolytic decomposition of hydrogenous materials) and volatile organic carbon (evolved from organic compounds potentially present in the waste matrix, e.g., xylene and toluene). The void space of a drum fills with a flammable gas, the concentration of which exceeds the lower explosive limit. All TRU drums are required to be vented (WHC-EP-0063). A buildup of flammable gas would, therefore, require either mechanical failure or plugging of the drum vent, improper installation of the drum vent, or failure to install a vent and subsequent failure to detect the absence of the vent. An undefined source of ignition sparks the gases and the resulting deflagration is sufficient to breach the drum and eject waste into the room. The ejected waste and the waste in the drum ignite and burn to completion. No credit is given to manual or automatic fire suppressions systems.

As addressed in Section 3.1.4.2.1, drums do not propagate fire.

3.1.4.3.2 Source Term. The source term for a drum explosion consists of five components:

- A release caused by the blast effects of the explosion $\left(A_{1}\right)$

- A release caused by burning of ejected combustible waste $\left(A_{2}\right)$

- A release caused by heating of ejected noncombustible waste $\left(A_{3}\right)$ 
- A release caused by burning of the combustible waste remaining in the drum $\left(A_{4}\right)$

- A release caused by heating of the noncombustible waste remaining in the drum $\left(A_{5}\right)$.

The explosion is sufficiently energetic to eject $10 \%$ of the waste from the drum because of the blast effects of the explosion. From experimental explosive testing of drums containing simulated waste at INEL, noted in Gas Generation: Year End Report (EG\&G 1983), it was determined that when a mixture of 14 vol\% $\mathrm{H}_{2}$ and a stoichiometric volume of $\mathrm{O}_{2}$ were ignited by a spark source within the drums, drums bulged but did not break. In a series of four tests with 30 vol\% $\mathrm{H}_{2}$ all drums ruptured. Lids were recovered up to $61 \mathrm{~m}$ (200 ft) away and various amounts of the simulated wastes (combustibles plus metals) were released. The release values for the four tests were $7 \%, 14 \%$, $27 \%$, and $41 \%$. In three of the tests, the nondispersed material also burned. Although the conditions represented in the tests are not identical to those of this analysis, much of the data can be used and inferences about the dispersion of similar waste material can be made. It was estimated that approximately $10 \%$ of a drum's gross contents would be ejected based upon the maximum anticipated hydrogen buildup in a drum and an extrapolation of the INEL test results, assuming $0 \%$ release at $14 \% \mathrm{H}_{2}$ and a maximum of $41 \%$ release at $30 \% \mathrm{H}_{2}$. Ten percent of the material ejected from the drum is not an ARF. It is emphasized that one tenth of all the rags and plastic, etc. in the drum are blown out of the drum and nine tenths stay in the drum to burn in place. In addition, the observation that, in three out of four tests, material not ejected from the drums was burned, was translated into the assumption that $100 \%$ of the material not made airborne burns. The TRU inventory at risk for single drum accidents is $400 \mathrm{~g} \mathrm{TRU}$, which at $1.29 \mathrm{Ci} / \mathrm{g}$, is equivalent to $516 \mathrm{Ci}$. The material ejected is therefore, $51.6 \mathrm{Ci}$.

The release resulting from the blast effects of the explosion acting on the ejected waste is calculated using an ARF of $1 \times 10^{-3}$ and a RF of 1.0 (DOE-HDBK-3010-94). This value is based on the ARF for an airborne release of powders caused by shock-vibration, which is based on $20 \%$ of the recommended ARF for the suspension of powders from a hard, unyielding surface because of accelerated flow generated by an explosion parallel to the surface. The 0.001 ARF is applied to the $10 \%$ ejected. The recommended RF is 1.0 . The release resulting from blast effects is therefore,

$$
\text { Activity } 1=(51.6 \mathrm{Ci}) \times\left(1 \times 10^{-3}\right)=5.16 \times 10^{-2} \mathrm{Ci}
$$

The release resulting from burning of the ejected combustible waste is calculated using an ARF of $1 \times 10^{-2}$ (DOE-HDBK-3010-94). This value is based on measured ARFs from three sets of experiments conducted on uncontained combustible materials and documented in The Amount and Characteristics of Plutonium Made Airborne Under Thermal Stress, BNWL-SA-3379 (Mishima and Schwendiman 1970). The recommended RF is 1.0 . The values are applied to the $84 \%$ of the drum contents that are combustible. The release resulting from burning of the ejected waste is therefore, 


$$
\text { Activity }_{2}=(51.6 \mathrm{Ci}-0.05 \mathrm{Ci}) \times(84 \%) \times\left(1 \times 10^{-2}\right)=4.33 \times 10^{-1} \mathrm{Ci}
$$

For thermal stress of contaminated, noncombustible solids, DOE-HDBK-3010-94 recommends bounding ARF and RF values of $6 \times 10^{-3}$ and 0.01 be used. This is based on the suspension of reactive powers under thermal stress in a flowing airstream and results in an overall airborne fraction of $\left(6 \times 10^{-3}\right) \times(0.01)=6 \times 10^{-5}$. The release resulting from heating noncombustible solids is therefore,

$$
\begin{aligned}
\text { Activity }_{3}=(51.6 \mathrm{Ci}-0.05 \mathrm{Ci}) \times(16 \%) \times\left(6 \times 10^{-5}\right) \\
=4.95 \times 10^{-4} \mathrm{Ci} .
\end{aligned}
$$

The release resulting from burning the combustible waste remaining in the drum that contains $464.4 \mathrm{C} i$, is based on an ARF of $5 \times 10^{-4}$, a RF of 1.0 , and $84 \%$ combustible materials (refer to Section 3.1.4.2.2 for development). The release is therefore,

$$
\text { Activity }_{4}=(464.4 \mathrm{Ci}) \times(84 \%) \times\left(5 \times 10^{-4}\right)=1.95 \times 10^{-1} \mathrm{Ci}
$$

The release resulting from heating the noncombustible waste remaining in the drum that contains $464.4 \mathrm{Ci}$, is based on an ARF and RF of $6 \times 10^{-5}$ and $16 \%$ noncombustible materials (refer to Section 3.1.3.2.2 for development). The release is therefore,

$$
\text { Activity }_{5}=(464.4 \mathrm{Ci}) \times(16 \%) \times\left(6 \times 10^{-5}\right)=4.46 \times 10^{-3} \mathrm{Ci} \text {. }
$$

The total activity airborne is therefore,

$$
\begin{gathered}
\text { Activity }_{\text {total }}=\left(5.16 \times 10^{-2}\right)+\left(4.33 \times 10^{-1}\right)+\left(4.95 \times 10^{-4}\right)+ \\
\left(1.95 \times 10^{-1}\right)+\left(4.46 \times 10^{-3}\right)=6.8 \times 10^{-1} \mathrm{Ci}
\end{gathered}
$$

TRUSAF drum storage areas are provided with a single stage of HEPA filtration (Section 2.4). This HEPA filter system is tested when installed to verify a filtering efficiency of at least $99.95 \%$. The system is tested on an annual basis thereafter. Taking credit for this system, the source term is 


$$
\text { Source term }=\left(6.8 \times 10^{-1} \mathrm{Ci}\right) \times(0.0005)=3.4 \times 10^{-4} \mathrm{Ci} \text {. }
$$

3.1.4.3.3 Consequences. The onsite and offsite radiological consequences of a drum explosion resulting in a source term of $6.8 \times 10^{-1} \mathrm{Ci}$, using the $X / Q$, the insoluble dose conversion, and the breathing rate values in Appendix $B$, are shown in Table 3-13. The consequences are considered unmitigated and provided to show that no credit for HEPA filtration is necessary to meet the risk criteria.

Table 3-13. Dose Consequences of Drum Explosion without HighEfficiency Particulate Air Filtration.

\begin{tabular}{|l|c|}
\hline \multicolumn{1}{|c|}{ Location } & Dose (rem) \\
\hline Onsite EDE & 5.7 \\
\hline Offsite EDE & $1.4 \mathrm{E}-01$ \\
\hline
\end{tabular}

$E D E$ = effective dose equivalent.

Applying the calculation evaluation method (Appendix B) with the consequence values, the onsite and offsite radiological consequences of a drum explosion accident resulting in a source term of $6.8 \times 10^{-1} \mathrm{Ci}$ are:

For the onsite EDE dose

$$
\begin{aligned}
& \mathrm{ST}=6.8 \times 10^{-1} \mathrm{Ci} \\
& (x / Q)=5.94 \times 10^{-4} \mathrm{~s} / \mathrm{m}^{3} \text { (Table B-1, Onsite Ground Level Release) } \\
& C=4.3 \times 10^{7}(\mathrm{rem} / \mathrm{Ci}) \text { (Table B-2, Pu, EDE) } \\
& \mathrm{R}=3.3 \times 10^{-4}\left(\mathrm{~m}^{3} / \mathrm{s}\right) \text { (ICRP 1975) } \\
& \text { Dose }(\text { rem })=S T(C i) \times\left[\frac{x}{Q}\right]\left(s / m^{3}\right) \times C(\mathrm{rem} / \mathrm{C} i) \times R\left(\mathrm{~m}^{3} / \mathrm{s}\right)= \\
& \left(6.8 \times 10^{-1} \mathrm{Ci}\right) \times\left(5.94 \times 10^{-4} \mathrm{~s} / \mathrm{m}^{3}\right) \times\left(4.3 \times 10^{7} \mathrm{rem} / \mathrm{Ci}\right) \\
& \times\left(3.3 \times 10^{-4} \mathrm{~m}^{3} / \mathrm{s}\right)=5.7 \text { rem. }
\end{aligned}
$$

For the offsite EDE dose

$$
\begin{aligned}
\mathrm{ST} & =6.8 \times 10^{-1} \mathrm{Ci} \\
(X / Q) & =1.48 \times 10^{-5} \mathrm{~s} / \mathrm{m}^{3} \text { (Table B-1, Offsite Ground Level Release) } \\
C & =4.3 \times 10^{7}(\mathrm{rem} / \mathrm{Ci}) \text { (Table B-2, Pu, EDE) } \\
\mathrm{R} & =3.3 \times 10^{-4}\left(\mathrm{~m}^{3} / \mathrm{s}\right) \text { (ICRP 1975) }
\end{aligned}
$$




$$
\begin{aligned}
& \text { Dose }(\text { rem })=S T(C i) \times\left[\frac{x}{Q}\right]\left(\mathrm{s} / \mathrm{m}^{3}\right) \times C(\mathrm{rem} / \mathrm{Ci}) \times R\left(\mathrm{~m}^{3} / \mathrm{s}\right)= \\
& \begin{array}{c}
\left(6.8 \times 10^{-1} \mathrm{Ci}\right) \times\left(1.48 \times 10^{-5} \mathrm{~s}^{3}\right) \times\left(4.3 \times 10^{7} \mathrm{rem} / \mathrm{Ci}\right) \\
\quad \times\left(3.3 \times 10^{-4} \mathrm{~m}^{3} / \mathrm{s}\right)=1.43 \times 10^{-1} \mathrm{rem} .
\end{array}
\end{aligned}
$$

3.1.4.3.4 Frequency. Flammability limitations (e.g., restrictions on the total head space concentration of potentially flammable volatile organic compounds) and specific packaging requirements (e.g., all plastic bagging is to have positive gas communication with outer package) for TRU waste drums are established to reduce the likelihood of explosions (WHC-EP-0063). Packaging errors leading to potentially explosive concentrations of flammable gas are expected to occur infrequently given the formality of TRU waste certification programs.

The frequency of a drum fire because of improper packaging of incompatible or pyrophoric materials was estimated to range from $1 \times 10^{-2} / \mathrm{yr}$ to $1 \times 10^{-4} / \mathrm{yr}$ (Section 3.1.4.2.4). The frequency of a drum explosion resulting from a flammable gas deflagration is estimated to range from $1 \times 10^{-3} / \mathrm{yr}$ to $1 \times 10^{-5} / \mathrm{yr}$ for this analys is. The order-of-magnitude reduction in the frequency estimate results from the requirement to vent the drums.

3.1.4.3.5 Conclusions. The upper boundary of the frequency estimate is used (i.e., $1 \times 10^{-3} / \mathrm{yr}$ ). The risk-acceptance guidelines are met without credit taken for HEPA filtration (Table 3-14). The onsite and offsite radiological consequences given a source term of $3.4 \times 10^{-4} \mathrm{Ci}$ (i.e., credit for HEPA filtration) are also shown in Table 3-14.

Table 3-14. Drum Explosion Comparison.

\begin{tabular}{|l|c|c|}
\hline \multirow{2}{*}{ Accident release } & Onsite dose (rem) & Offsite dose (rem) \\
\cline { 2 - 3 } & EDE & EDE \\
\hline $3.4 \mathrm{E}-04$ Ci source term $^{(a)}$ & $2.9 \mathrm{E}-03$ & $7.0 \mathrm{E}-05$ \\
\hline $6.8 \mathrm{E}-01$ Ci source term $^{(\mathrm{b})}$ & 5.7 & $1.4 \mathrm{E}-01$ \\
\hline Dose guidel ine & & 1.4 \\
\hline
\end{tabular}

(a) HEPA-filtered release.

(b) Nonfil tered release.

(c) From WHC 1995a for a $1 \times 10^{-3} / \mathrm{yr}$ event.

$E D E$ = effective dose equivalent. 
As documented in Section 3.1.4.2.1, no fire propagation occurs between drums, except when the drums are directly within the flames of an extended hydrocarbon fuel fire or where drums are on combustible pallets adjacent to a hydrocarbon fuel fire. Note that the single drum scenario assumes that the installed fire detection/suppression systems are not activated.

\subsubsection{Seișmic Event.}

3.1.4.4.1 Scenario. TRUSAF provides a seismically-qualified storage structure, unlike most of the TRU storage facilities at the Hanford Site and across the DOE Complex. This stems from the building's original plutonium processing mission. The 224-T Building is capable of continued operation with all containment systems operational following an operational bas is earthquake with a maximum horizontal ground acceleration of $0.12 \mathrm{~g}$. As constructed, the building will withstand a horizontal acceleration of $0.25 \mathrm{~g}$. A simultaneous vertical acceleration of two-thirds the horizontal ground acceleration is associated with both earthquakes.

Current seismic design criteria for Hanford Site facilities is established in SDC-4.1 Standard Architectural-Civil, Design Loads for Facilities, Rev. 12 (1993). This criteria is shown in Table 3-15. Note that operational basis earthquakes currently are defined only for Safety Class 1 (i.e., high-hazard) structures. The 224-T Building exceeds all current seismic design criteria, regardless of assigned safety class (Table 3-15).

Table 3-15. Seismic Design Criteria.

\begin{tabular}{|l|c|}
\hline \multicolumn{1}{|c|}{ Classification } & DBE (g) \\
\hline Safety Class 1 (high hazard) & 0.20 \\
\hline Safety Class 2 (moderate hazard) & $0.12^{*}$ \\
\hline Safety Class 3 (low hazard) & 0.12 \\
\hline Safety Class 4 (general use) & 0.09 \\
\hline
\end{tabular}

"Differs from SC-3 in critical damping and importance factor

values and in analytical techniques.

$\mathrm{DB}=$ design-basis earthquake.

A seismic event in excess of the previously defined TRUSAF operational bas is earthquake (i.e., $0.12 \mathrm{~g}$ ) is assumed to occur in this analys is. It is postulated that drums fall from stacks and that the HEPA-filtered ventilation system fails, but no facility structural failures occur.

3.1.4.4.2 Source Term. TRUSAF drums are stacked a maximum of two high. This is a physically imposed limit because of the ceiling height and installed services and utilities (e.g., lighting). The maximum distance a drum would fall is $1 \mathrm{~m}(3 \mathrm{ft})$. All TRUSAF waste storage drums meet DOT drop test requirements for Type $A$ containers ( $i . e .$, a drop test height of $1.2 \mathrm{~m} \mathrm{[4} \mathrm{ft}]$ ), so no drum failures are postulated. Note that studies have shown that DOT 17C 
drums can survive falls from heights significantly $>1.2 \mathrm{~m}$ (4 ft) without loss of containment (Huerta et al., 1983).

Failure of the HEPA filtered ventilation system could result in the release of both the airborne activity present in the process cells and the activity accumulated on filters. Airborne activity in the process cells will be available for release following the seismic event if the HEPA filter system fails. Information regarding the estimated radiological inventory of the process cells is provided by WHC-SD-WM-ES-288, Rev. 0 (WHC 1994d). The non-TRU radionuclide inventory was estimated to be $25 \mathrm{C} i$, consisting of

- $1.0 \mathrm{Ci}$ of ${ }^{137} \mathrm{Cs}$
- $21 \mathrm{Ci}$ of ${ }^{90} \mathrm{Sr}$
$\quad 3.6 \mathrm{Ci}$ of ${ }^{60} \mathrm{Co}$.

The TRU inventory was estimated to be 36 curies, consisting of

- $5.2 \mathrm{Ci}$ of ${ }^{239} \mathrm{Am}$

- $31 \mathrm{Ci}$ of ${ }^{239} \mathrm{Pu}$.

The release from the process cells is calculated using an ARF of $2 \times 10^{-3}$, a RF of 0.3 , and a leak path factor of 1.0 . The ARF and RF value represents the bounding value of free-fall spills of powders (DOE-HDBK-3010-94). The estimated isotopic inventory is expected to be in piping, tanks, and centrifuges (Appendix D). However, a leak path factor of 1.0 is used, because of uncertainty in the actual configuration.

The estimated dose from the isotopic inventory of the 224-T Building process cells is provided in Appendix B. This dose assumes that all of the isotopic inventory of the process cells was inhaled. The inventory is respirable material and is given in rems which were calculated from curies without the breathing rate considered. The calculated dose potential for the process cells is

$$
\text { Dose }_{\mathrm{EDE}}=\left(2.9 \times 10^{10} \mathrm{rem}\right) \times(0.002) \times(0.3)=1.74 \times 10^{7} \mathrm{rem} .
$$

NOTE: The curie dose conversion factor has already been included in the calculations. This is not a true dose projection.

The inventory at risk on HEPA filters can be estimated from the detected activity on filters removed from service. The radionuclide inventory of eight prefilters and four HEPA filters was characterized by wide-area, gamma-energy analysis and neutron flux measurements following the change-out of filters in 1990 and was document by Radiological Characterization of Discharged Packaged HEPA Filters (Subrahmanyam 1990). The total TRU and MFP inventory calculated by Subrahmanyam on the prefilters was $1.22 \times 10^{-4} \mathrm{Ci}$ and $2.28 \times 10^{-6} \mathrm{Ci}$. The total TRU and MFP inventory on the HEPA filters was $1.09 \times 10^{-4} \mathrm{Ci}$ and $2.59 \times$ $10^{-5} \mathrm{Ci}$. There are 36 prefilters and $40 \mathrm{HEPA}$ filters, so the inventory at risk is $1.64 \times 10^{-3} \mathrm{Ci}$ of TRU and $2.69 \times 10^{-4} \mathrm{Ci}$ of MFP, as shown in Equations 24-27. 


$$
\operatorname{TRU}_{\text {HEPA }}=\frac{1.09 \times 10^{-4} \mathrm{Ci}}{4 \text { filters }} \times 40 \text { filters }=1.09 \times 10^{-3} \mathrm{Ci} \text {. }
$$

$$
\begin{aligned}
& \operatorname{TRU}_{\text {prefilter }}=\frac{1.22 \times 10^{-4} \mathrm{Cj}}{8 \mathrm{filters}} \times 36 \text { filters }=5.49 \times 10^{-4} \mathrm{Ci} \\
& \mathrm{TRU}_{\text {total }}=1.09 \times 10^{-3} \mathrm{Ci}+5.49 \times 10^{-4} \mathrm{Ci}=1.64 \times 10^{-3} \mathrm{Ci} \\
& \mathrm{MFP}_{\text {HEPA }}=\frac{2.59 \times 10^{-5} \mathrm{Ci}}{4 \mathrm{fi} \text { ters }} \times 40 \text { filters }=2.59 \times 10^{-4} \mathrm{Ci}
\end{aligned}
$$

$$
\begin{aligned}
& \text { MFP }_{\text {prefilter }}=\frac{2.28 \times 10^{-6} \mathrm{Cj}}{8 \mathrm{filters}} \times 36 \text { filters }=1.03 \times 10^{-5} \mathrm{Ci} \\
& M F P_{\text {total }}=2.59 \times 10^{-4} \mathrm{Ci}+1.03 \times 10^{-5} \mathrm{Ci}=2.69 \times 10^{-4} \mathrm{Ci}
\end{aligned}
$$

A series of studies was conducted on particles generated by HEPA filters. As noted in Characterization of Spent HEPA Filters from Rocky Flats Plant (Arnold 1986), the filters were subjected to repetitive slamming and crushing on a hard, unyielding surface. The upper bound ARF for particles $\leq 10 \mu \mathrm{m}$ was $5 \times 10^{-3}$ with a median and an average of $2 \times 10^{-3}$ for impacts. The ARF for particles $\leq 10 \mu \mathrm{m}$ ranged from $1 \times 10^{-5}$ to $7 \times 10^{-3}$ for crushing of filters. A conservative ARF of $1 \times 10^{-2}$ is recommended (DOE-HDBK-3010-94) The associated recommended RF is 1.0. The TRU airborne activity is therefore,

$$
\text { TRU Activity } \text { filters }=\left(1.64 \times 10^{-3} \mathrm{Ci}\right) \times\left(1 \times 10^{-2}\right)=1.64 \times 10^{-5} \mathrm{Ci}
$$

and the MFP airborne activity is

$$
\begin{aligned}
\text { MFP Activity }_{\text {filters }} & =\left(2.69 \times 10^{-4} \mathrm{Ci}\right) \times\left(1 \times 10^{-2}\right) \\
& =2.69 \times 10^{-6} \mathrm{Ci}
\end{aligned}
$$


3.1.4.4.3 Consequences. The onsite and offsite radiological consequences of a seismic event resulting from the calculated source term, and using the $x / Q$ and breathing rate values, (Appendix $B$ ) are shown in Table 3-16.

Table 3-16. Dose Consequences of Seismic Event.

\begin{tabular}{|l|c|}
\hline \multicolumn{1}{|c|}{ Location } & Dose (rem) \\
\hline Onsite EDE & 3.4 \\
\hline Offsite EDE & $8.5 \times \mathrm{E}-02$ \\
\hline
\end{tabular}

$E D E=$ effective dose equivalent.

Onsite and offsite dose consequence from process cells are:

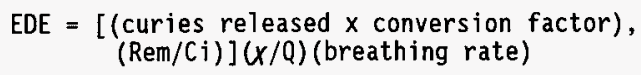

$$
\begin{gathered}
\text { Onsite }_{\text {EDE }}=\left(1.74 \times 10^{7}\right)\left(5.94 \times 10^{-4}\right)\left(3.3 \times 10^{-4}\right)=3.4 \mathrm{rem} \\
\text { Offsite }_{E D E}=\left(1.74 \times 10^{7}\right)\left(1.48 \times 10^{-5}\right)\left(3.3 \times 10^{-4}\right)=8.5 \times 10^{-2} \mathrm{rem}
\end{gathered}
$$

Onsite and offsite dose consequence from filters are:

$$
\begin{aligned}
\text { EDE } & =\begin{array}{c}
\text { (curies released) }(\times / Q)(\text { breathing rate }) \\
(\text { conversion factor, Rem/Ci })
\end{array} \\
\text { Onsite }_{\text {TRU }} & =\left(1.64 \times 10^{-5}\right)\left(5.94 \times 10^{-4}\right)\left(3.3 \times 10^{-4}\right)\left(6.0 \times 10^{7}\right) \\
& =1.93 \times 10^{-4} \mathrm{rem} \\
\text { offsite }_{\text {TRU }}= & \left(1.64 \times 10^{-5}\right)\left(1.48 \times 10^{-5}\right)\left(3.3 \times 10^{-4}\right)\left(6.0 \times 10^{7}\right) \\
= & 4.81 \times 10^{-6} \mathrm{rem} \\
\text { Onsite }_{\text {MFP }}= & \left(2.69 \times 10^{-6}\right)\left(5.94 \times 10^{-4}\right)\left(3.3 \times 10^{-4}\right)\left(2.1 \times 10^{5}\right) \\
& =1.11 \times 10^{-7} \mathrm{rem} \\
\text { Offsite }_{\text {MFP }} & =\left(2.69 \times 10^{-6}\right)\left(1.48 \times 10^{-5}\right)\left(3.3 \times 10^{-4}\right)\left(2.1 \times 10^{5}\right) \\
& =2.76 \times 10^{-9} \mathrm{rem}
\end{aligned}
$$


The consequences from the process cell release bound those resulting from failure of filters. The dose consequences resulting from the filter release are insignificant when compared to the consequences resulting from the process cells.

3.1.4.4.4 Frequency. Natural Phenomena Hazards Modeling Project: Seismic Hazard Models for Department of Energy Sites, UCRL-53582, found that the frequency of a seismic event $>0.12 \mathrm{~g}$ at the Hanford Site is $1 \times 10^{-3} / \mathrm{yr}$ (Coates et al. 1984). This value was derived using a probabilistic methodology in which faults are identified based on the geology and historic seismicity of the region and the largest magnitude earthquake associated with each fault established. The recurrence of earthquakes of various magnitudes at each fault is then modeled based on past seismicity and assuming that earthquake occurrence follows a Poisson distribution in time. Transfer functions are applied to determine the ground acceleration at a specific location. These functions (or attenuation relationships) are empirically derived from existing strong motion data by regression analysis of the peak ground acceleration versus earthquake magnitude and distance from the epicenter. The potential activity of all faults for all earthquake magnitudes is combined to determine the probability that a certain acceleration will not be exceeded within a given time period.

3.1.4.4.5 Conclusions. The risk associated with a seismic event meets the risk-acceptance guidelines established in WHC 1995a (Table 3-17).

Table 3-17. Seismic Event Comparison.

\begin{tabular}{|l|c|c|}
\hline \multirow{2}{*}{ Accident release } & Onsite dose (rem) & 0ffsite dose (rem) \\
\cline { 2 - 3 } & EDE & EDE \\
\hline Seismic event doses & 3.4 & $8.5 \mathrm{E}-02$ \\
\hline Dose guideline & 11 & 1.4 \\
\hline
\end{tabular}

${ }^{\star}$ From WHC 1995a for a $1 \times 10^{-3} / \mathrm{yr}$ event.

$E D E$ = effective dose equivalent.

3.1.4.5 Bounding Toxicological Analysis. The inventory of TRUSAF hazardous materials is quantified in Table 3-8. Only six of the twenty-seven materials are present in five or more drums at an average loading of $>0.5 \mathrm{~kg} / \mathrm{drum}$. The inventory data for these six materials is presented in Table 3-18.

of the chemicals 1 isted in Table 3-18, carbon tetrachloride $\left(\mathrm{CCl}_{4}\right)$ presents the greatest risk for the accident scenarios analyzed in Sections 3.1 .4 .1 through 3.1 .4 .5 based on its volatility. The remaining materials are solids with the exception of tributyl phosphate, which is relatively nonvolatile (i.e., a boiling point of $148^{\circ} \mathrm{C}$ [298 ${ }^{\circ} \mathrm{F}$ ] versus $25^{\circ} \mathrm{C}$ $\left[77^{\circ} \mathrm{F}\right]$ for $\left.\mathrm{CCl}_{4}\right)$. 
Table 3-18. Significant Hazardous Materials at the

Transuranic Waste Storage and Assay Facility.

\begin{tabular}{|l|c|c|c|c|c|}
\hline \multicolumn{1}{|c|}{ Hazardous waste } & $\begin{array}{c}\text { Number of } \\
\text { containers }\end{array}$ & $\begin{array}{c}\text { Maximum } \\
(\mathrm{kg})\end{array}$ & $\begin{array}{c}\text { Minimum } \\
(\mathrm{kg})\end{array}$ & $\begin{array}{c}\text { Average } \\
(\mathrm{kg})\end{array}$ & $\begin{array}{c}\text { Facility } \\
\text { tota } \\
(\mathrm{kg})\end{array}$ \\
\hline Asbestos & 6 & 27.0022 & 0.5000 & 7.5673 & 45.40 \\
\hline Cadmium & 25 & 89.9923 & 0.0000 & 3.7794 & 94.48 \\
\hline Carbon tetrachloride & 16 & 15.3994 & 0.0100 & 5.5744 & 89.19 \\
\hline Lead & 207 & 123.3765 & 0.0250 & 17.9949 & 3724.94 \\
\hline Lead chromate & 20 & 7.9700 & 0.0100 & 1.1438 & 22.87 \\
\hline Tributyl phosphate & 8 & 5.9012 & 4.0002 & 5.4260 & 43.40 \\
\hline
\end{tabular}

3.1.4.5.1 Scenario. The assumed bounding toxicological analysis involves a delivery truck carrying drums of $\mathrm{CCl}_{4}$ impacting the 224-T Building. The truck loses control and impacts the building at a speed sufficient to rupture the fuel tank. Resultant heat and/or sparks ignite the fuel. The intensity and duration of the fire ignites the contents of the drums on the truck. No credit is taken for fire fighting efforts on behalf of facility personnel.

3.1.4.5.2 Source Term. Sixteen drums contain $89.19 \mathrm{~kg}$ of $\mathrm{CCl}_{4}$, a quantity equal to the current building inventory. It is assumed that all of the $\mathrm{CCl}_{4}$ is released at a unjform rate over a 15 min time period. The release rate is therefore, $9.91 \times 10^{4} \mathrm{mg} / \mathrm{s}$.

3.1.4.5.3 Consequences. Onsite and offsite $\mathrm{CCl}_{4}$ concentrations are calculated by multiplying the release rate $(\mathrm{mg} / \mathrm{s})$ by the applicable $x / 0\left(\mathrm{~s} / \mathrm{m}^{3}\right)$ values. The $X / Q$ values for buoyant plume $r i s e$ with building wake and $p l$ ume trapping are used for truck fire scenarios. The concentrations are shown in Table 3-19 and are derived in the following calculations.

Onsite Carbon Tetrachloride Concentration

$$
9.91 \times 10^{4} \mathrm{mg} / \mathrm{s} \times 3.14 \times 10^{-5} \mathrm{~s} / \mathrm{m}^{3}=3.1 \mathrm{mg} / \mathrm{m}^{3}
$$

Offsite Carbon Tetrachloride Concentration

$$
9.91 \times 10^{4} \mathrm{mg} / \mathrm{s} \times 3.75 \times 10^{-6} \mathrm{~s} / \mathrm{m}^{3}=0.37 \mathrm{mg} / \mathrm{m}^{3}
$$


Table 3-19. Carbon Tetrachloride Concentrations.

\begin{tabular}{|l|c|}
\hline \multicolumn{1}{|c|}{ Location } & Concentration \\
\hline Onsite & $3.1 \mathrm{mg} / \mathrm{m}^{3}=0.52 \mathrm{ppm}$ \\
\hline Offsite & $0.37 \mathrm{mg} / \mathrm{m}^{3}=0.06 \mathrm{ppm}$ \\
\hline
\end{tabular}

At elevated temperatures, $\mathrm{CCl}_{4}$ can thermally decompose to form phosgene $\left(\mathrm{COCl}_{2}\right)$. In "Therma1 Decomposition of Carbon Tetrachloride Vapors at Its Industrial Threshold Limit Value" (Noweir et al., 1973), a stream of $\mathrm{CCl}_{4}$ vapors at a concentration of $10 \mathrm{ppm}$ was passed through a decomposition furnace over various substrates at various temperatures. When $\mathrm{CCl}_{4}$ was passed over a glass surface no phosgene was detected below $500{ }^{\circ} \mathrm{C}$ and at $730{ }^{\circ} \mathrm{C}$ a maximum of about $10 \mathrm{ppm}$ was detected. When passed over a clean iron surface the phosgene gas concentration was less than $0.25 \mathrm{ppm}$ beginning at $300{ }^{\circ} \mathrm{C}$ and was fairly constant over the studied temperatures (i.e., up to $900^{\circ} \mathrm{C}$ ). When passed over a corroded iron surface phosgene was detected beginning at about $210^{\circ} \mathrm{C}$ and reached a maximum concentration of $1.9 \mathrm{ppm}$ at $465^{\circ} \mathrm{C}$. For this scenario, it is assumed that phosgene gas generation will occur at the same proportion for $\mathrm{CCl}_{4}$ when passed over a clean iron surface as previously discussed because the waste drums are clean and made of steel (i.e., $0.25 \mathrm{ppm}$ phosgene gas/ $10 \mathrm{ppm} / \mathrm{CCl}_{4}$, or $0.025 \mathrm{ppm}$ phosgene/ppm $\left.\mathrm{CCl}_{4}\right)$. The concentrations of phosgene gas generated in the vehicle fire are shown in Table 3-20.

Table 3-20. Phosgene $\left(\mathrm{COCl}_{2}\right)$ Gas Concentrations.

\begin{tabular}{|c|c|c|c|}
\hline Location & \multicolumn{3}{|c|}{ Concentration } \\
\hline Onsite & $\left.(0.52 \mathrm{ppm} \mathrm{CCl})_{4}\right)(0.025$ & $\frac{\mathrm{ppm} \mathrm{COCl}}{2}$ & $=0.013 \mathrm{ppm} \mathrm{COCl} l_{2}$ \\
\hline Offsite & $\left.(0.06 \mathrm{ppm} \mathrm{CCl})_{4}\right) 0.025$ & $\frac{\mathrm{ppm} \mathrm{COCl}_{2}}{\mathrm{ppm} \mathrm{CCl}}$ & $=0.0002 \mathrm{ppm} \mathrm{COCl} \mathrm{Cl}_{2}$ \\
\hline
\end{tabular}

3.1.4.5.4 Frequency. A delivery truck must lose control and crash, the severity of the crash must be sufficient to breach the fuel tank, and the fuel must ignite in order for the truck fire scenario to occur. The truck could lose control because of an equipment failure (e.g., brakes, steering), or an operator error. An operator error is assumed for this analysis and a frequency of $1 \times 10^{-3} /$ delivery is app 1 ied. Fires occur in 0.4 percent of accidents in which a truck collides with a fixed object (Clarke 1976). Order of magnitude reduction is applied to account for the slow speeds within the 
fenced area surrounding the 224-T Building relative to highway/freeway speeds. This yields a probability of $4 \times 10^{-4}$. The frequency of a truck accident resulting in a fire is therefore $4 \times 10^{-7} /$ delivery. The TRUSAF receives $\approx 24$ TRU waste shipments per year, based on past operating history. However, fifty deliveries per year is assumed. The frequency of truck fire is therefore:

$$
\text { Frequency } \text { truckfire }=\left(\frac{4 \times 10^{-7}}{\text { delivery }}\right) \times\left(\frac{50 \text { deliveries }}{\text { year }}\right)=2.0 \times 10^{-5} / \text { year. }
$$

3.1.4.5.5 Conclusions. Toxicological risk-acceptance guidelines are established in accord with the Emergency Response Planning Guide Series (AIHA 1991). The Emergency Response Planning Guide 1, 2, and 3 values for $\mathrm{CCl}_{4}$ are $20 \mathrm{ppm}, 100 \mathrm{ppm}$, and $750 \mathrm{ppm}$. The onsite and offsite risk-acceptance guidelines for $\mathrm{CCl}_{4}$, given an event frequency of $2 \times 10^{-5} / \mathrm{yr}$, are shown on Figure 3-2.

The Emergency Response Planning Guide 1,2 , and 3 value for $\operatorname{COCl}_{2}$ are $E R P G-1=$ not applicable, $E R P G-2=0.2 \mathrm{ppm}$, and $E R P G-3=1 \mathrm{ppm}$. The onsite and offsite risk acceptance guidelines for $\mathrm{COCl}_{2}$, given an event frequency of $2 \times 10^{-5}$, are shown in Figure 3-3.

Comparing the calculated $\mathrm{CCl}_{4}$ release concentrations in Table 3-19 and $\mathrm{COC} 1_{2}$ concentrations in Table 3-20 to their respective Figures $3-2$ and $3-3$, it is shown that $\mathrm{CCl}_{4}$ and $\mathrm{COCl}_{2}$ concentrations do not exceed the risk guidelines.

The above analysis is based on TRUSAF hazardous material inventory as of April 1994. Future waste shipments may include the same or other hazardous materials in quantities that cannot be estimated at this time. All such wastes must comply with WHC-EP-0063, which controls waste characterization and packaging requirements. 
Figure 3-2. $\mathrm{CCl}_{4}$ Carbon Tetrachloride Risk Comparison Guidelines.

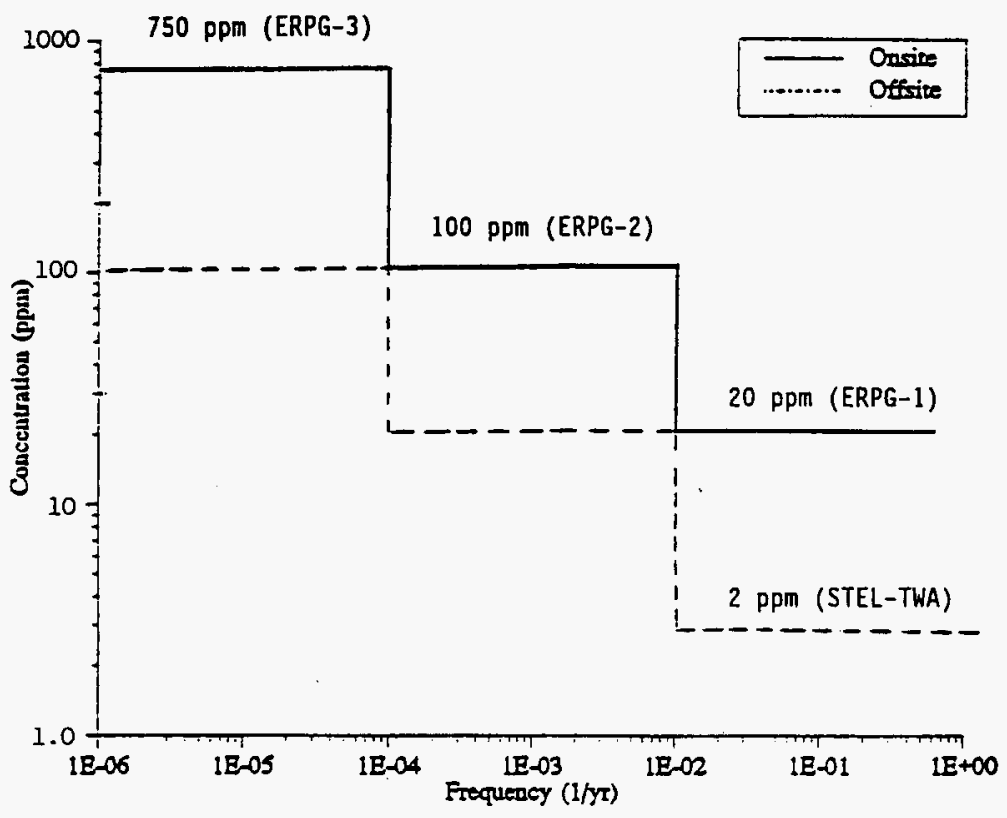


Figure 3-3. $\mathrm{COCl}_{2}$ Phosgene Risk Comparison Guidelines.

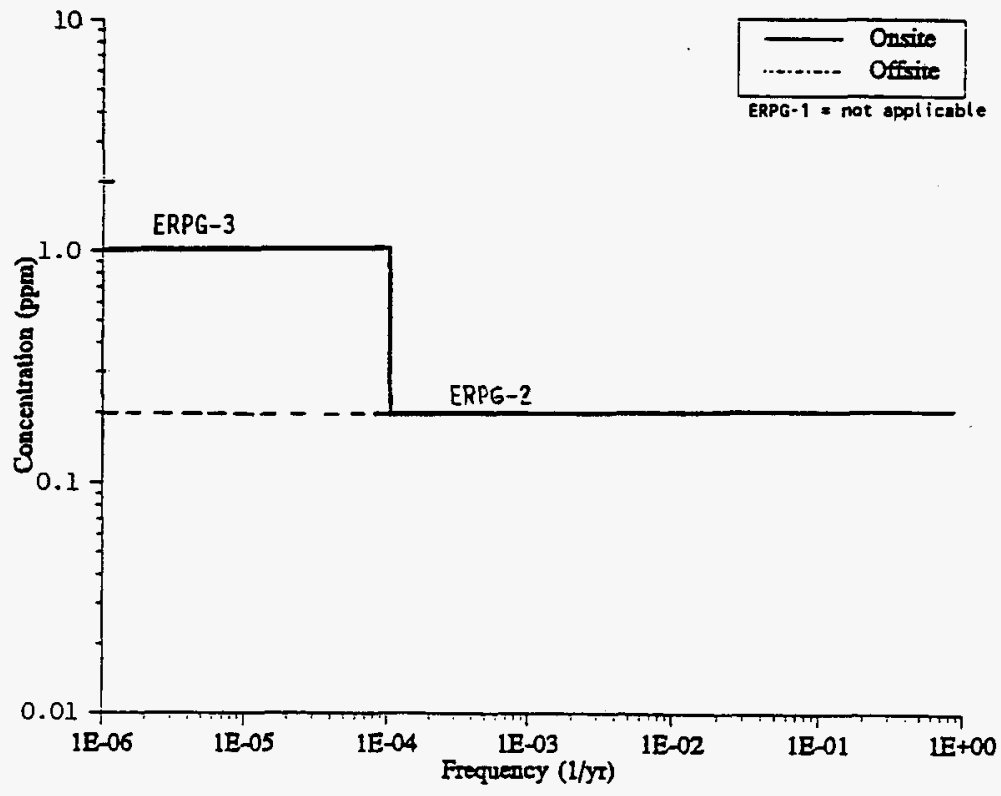


Retrieved waste to be received at TRUSAF represents one exception to compliance with WHC-EP-0063, because it was packaged under older, varying requirements. None of the sites designated for vented-drum retrieval are known to contain significant amounts of mixed waste. Contact-Handled Transuranic Waste Characterization Based on Existing Records (Anderson 1990) shows that only about two percent of the total drums in TRU retrieval storage will contain mixed waste. The hazardous materials identified in waste records are shown in Table 3-21.

Table 3-21. Hazardous Materials in Retrieved Drums.

\begin{tabular}{|l|c|c|}
\hline \multicolumn{1}{|c|}{ Material } & Inorganic & Organic \\
\hline Antifreeze & & $\mathrm{x}$ \\
\hline Asbestos & $\mathrm{x}$ & \\
\hline Beryllium & $\mathrm{x}$ & \\
\hline Cadmium & & $\mathrm{x}$ \\
\hline Carbon tetrachloride & $\mathrm{x}$ & \\
\hline Copper & & $\mathrm{x}$ \\
\hline Hydraulic fluid & $\mathrm{x}$ & \\
\hline Lead & $\mathrm{x}$ & \\
\hline Lithium & $\mathrm{x}$ & \\
\hline Nitric acid & & $\mathrm{x}$ \\
\hline PCB & $\mathrm{x}$ & \\
\hline Sodium & $\mathrm{x}$ & \\
\hline Sodium hydroxide & & $\mathrm{x}$ \\
\hline Stripcoat & & $\mathrm{x}$ \\
\hline Tributyl phosphate & $\mathrm{x}$ & \\
\hline Trichloromethane & & \\
\hline Zirconium & & \\
\hline
\end{tabular}

$\mathrm{PCB}=$ polychlorinated biphenyl.

Analyses of potential hazardous material releases associated with retrieved drums are documented in WHC-SD-WM-SAR-058, Rev. 0 (WHC 1994a). This document concludes that spills of hazardous materials will result in consequences within acceptable exposure limits, and therefore, have little, if any, associated risk. 


\subsubsection{Basis for Inventory Control}

DOE-STD-1027-92 provides guidance for determination of the final hazard categorization once a Hazards Analysis has been performed. This concept can be used to define the inventory limits necessary to maintain safe storage capacity at TRUSAF. The Standard states

The final categorization is based on an "unmitigated release" of available hazardous material. For the purposes of hazard categorization, "unmitigated" is meant to consider material quantity, form, location, dispersibility and interaction with available energy sources, but not to consider safety features (e.g., ventilation system, fire suppression, etc.) which will prevent or mitigate a release.

Operations at a facility that are below the Hazard Category 2 Threshold Quantities, by definition, have the potential for only significant localized consequences. Limiting the facility inventory such that the hazards analysis shows any credible accident will remain below the criteria used to establish hazard category 2 threshold quantities, ensures that the operation should be defined as having the potential for only significant localized consequences.

DOE-STD-1027-92, in deriving the threshold quantities for a Category 2 facility, utilizes a maximum onsite dose of 1 rem EDE based upon meteorological conditions of stability class $D$ at a wind velocity of $4.5 \mathrm{~m} / \mathrm{sec}$. This methodology was constructed from existing regulations which define minimum thresholds for many radionuclides and hazardous chemicals. The derived quantities were based on the consequences from these hazards in the immediate vicinity of a facility. For radioactive materials, 10CFR30 derived quantities were established above which licensees must provide emergency plans for responding to a release, and the use of a similar approach should be conservatively applicable to an onsite receptor. For the TRUSAF, the nearest normally occupied onsite facility outside of the Solid Waste Disposal (SWD) Emergency Plan area is Office Building MO-279, located $500 \mathrm{~m}$ SSE. Use of the same DOE-STD-1027-92 meteorological conditions (stability class $D$ at a wind velocity of $4.5 \mathrm{~m} / \mathrm{sec}$ ), taking no credit for building wake or plume meander, results in a $X / Q$ of $3.65 E-05 \mathrm{~s} / \mathrm{m}^{3}$ (WHC 1996b). This $X / Q$ is used for purposes of hazard classification in this section of this document for calculating the onsite radiological doses for the onsite receptor for potential accident releases from TRUSAF. If the onsite radiological consequences at $500 \mathrm{~m}$ SSE are less than 1 rem EDE using a $X / Q$ of $3.65 \mathrm{E}-05$ $\mathrm{s} / \mathrm{m}^{3}$, then the TRUSAF can be considered as having the potential for on $1 \mathrm{y}$ significant localized consequences. If the radiological doses exceed 1 rem EDE at $500 \mathrm{~m}$ SSE, then TRUSAF hazard analysis would be considered to show the potential for significant onsite consequences.

The forklift and drum fire accidents are bounded by the waste drum deflagration accident (i.e., the inventory at risk for the forklift and drum fire accidents is less than for the drum deflagration accident). The waste drum deflagration accident is discussed in Section 3.1.4.3. The vehicle fire accident discussed occurs outside TRUSAF and has no impact on the inventory stored within the facility. Therefore, the vehicle fire accident is not considered when determining the hazard category. 
As noted in Design Criteria Structural Modifications 224-T Building (Nelson and Smith 1971), the TRUSAF design includes the following earthquake resistance.

The building shall be capable of continued operation with all containment systems operational following an Operating Basis Earthquake which will provide a maximum horizontal ground acceleration of $0.12 \mathrm{~g}$. ground acceleration shall be assumed as two-thirds of the horizontal acceleration. The structure shall withstand the forces and sustain only minor repairable damage. Under maximum conditions, a Design Basis Earthquake with $0.25 \mathrm{~g}$. maximum horizontal ground acceleration shall be applied (vertical ground acceleration equals two-thirds of the horizontal acceleration).

Under DB conditions, the building shall be capable of preventing serious damage to the scrap containers and all containment systems shail be capable of preventing a serious flow reversal. Continued use of the building need not be assured, but all scrap containers shall be safely recoverable.

Based on the seismic design none of the material contained in drums in TRUSAF TRU inventory is at risk. The seismic accident scenario described in Section 3.1.4.5 show the radioactive material on the filters at risk to be $1.65 \times 10^{-3}$ plutonium equivalent-curies (PE-Ci) for TRU and $2.7 \times 10^{-4} \mathrm{Ci}$ for mixed fission products (MFP). ${ }^{\circ}$ These values are insignificant when compared to the following process cell inventory. The process cell inventory is identified in section 3.1 .4 .4 .2 as $5.2 \mathrm{Ci}$ of ${ }^{241} \mathrm{Am}, 31 \mathrm{Ci}$ of ${ }^{239} \mathrm{Pu}$, and 25.6 Ci of MFP. The DOE-STD-1027-92 Hazard Class 2 threshold quantities are $5.5 \times 10^{1} \mathrm{Ci}$ for ${ }^{241} \mathrm{Am}, 5.6 \times 10^{1} \mathrm{Ci}$ for ${ }^{239} \mathrm{Pu}$ and $2.5 \times 10^{6} \mathrm{Ci}$ for MFP. The inventories at risk from TRUSAF process cells for a seismic event are less than the DOE-STD-1027-92 threshold quantities for Hazard Category 2.

Therefore, the waste drum deflagration accident, which is discussed in Section 3.1.4.3, is the bounding accident for the TRUSAF facility. Based on the discussion in this section concerning the determination of the inventory control, the drum deflagration accident was selected as the bounding accident for determining the quantities, to ensure that only significant localized consequences could occur, because its onsite and offsite dose consequences were the largest of all of the accidents tabulated in Table 1-1. Note that the vehicle fire accident has been dropped from the analys is because it is

${ }^{a} 0.12 \mathrm{~g}$ and $0.25 \mathrm{~g}$ are the maximum likely and maximum credible earthquake ground accelerations for the Hanford Area, as defined by Report on the Seismicity of the Hanford Washington Area (U.S. Coast Guard 1967).

${ }^{\mathrm{B}} \mathrm{PE}-\mathrm{C} \mathrm{i}$ is the concept where all of the radiological activities, in curies, attributable to the individual isotopes present in TRU material are converted to an equivalent activity of ${ }^{239} \mathrm{Pu}$ in curies. Mixed fission products (MFP) are those isotopes formed in the fission process. Specifically excluded are isotopes included in the definition of TRU material. 
external to the facility. As discussed in Section 3.1.3, a criticality event has been judged to be an incredible event at TRUSAF and no postulated accident scenario has been identified that would release container contents, such that sufficient mass to support criticality would occur.

Applying this calculational evaluation method with the source term value of $6.8 \times 10^{-1} \mathrm{Ci}$ calculated in Section 3.1.4.3.2 for the drum explosion scenario, the onsite radiological consequences are:

For the onsite EDE dose

$$
\begin{aligned}
& \mathrm{ST}=6.8 \times 10^{-1} \mathrm{Ci} \\
& (x / Q)=3.65 \times 10^{-5} \mathrm{~s} / \mathrm{m}^{3} \\
& C=4.3 \times 10^{7}(\text { rem/Ci) (Table B-2, Pu, EDE) } \\
& R=3.3 \times 10^{-4}\left(\mathrm{~m}^{3} / \mathrm{s}\right)(\text { ICRP 1975) } \\
& \text { Dose }(\text { rem })=S T(C j) \times\left[\frac{X}{Q}\right]\left(s / m^{3}\right) \times C(\text { rem } / C i) \times R\left(m^{3} / s\right)= \\
& \left(6.8 \times 10^{-1} \mathrm{Ci}\right) \times\left(3.65 \times 10^{-5} \mathrm{~s} / \mathrm{m}^{3}\right) \times\left(4.3 \times 10^{7} \mathrm{rem} / \mathrm{Ci}\right) \\
& x\left(3.3 \times 10^{-4} \mathrm{~m}^{3} / \mathrm{s}\right)=.35 \mathrm{rem} .
\end{aligned}
$$

Since the drum explosion is the bounding accident at the TRUSAF (i.e. results in the maximum release quantity), this shows that all unmitigated radiological consequences are well below 1 rem EDE onsite, using the DOE-STD1027-92 meteorological conditions (stability class D at a wind velocity of 4.5 $\mathrm{m} / \mathrm{sec}$ ). It is demonstrated that the facility can maintain safe storage with only significant localized onsite consequences, when a $400 \mathrm{~g}$ drum of $12 \%{ }^{240} \mathrm{Pu}$ aged 20 years is involved.

Calculations to determine the maximum material at risk and the corresponding sum of fractions for a deflagration accident, involving a drum containing $400 \mathrm{~g}$ of $12 \%{ }^{240} \mathrm{Pu}$ aged 20 years, indicate that TRUSAF wi11 maintain safe storage with only significant localized onsite consequences. Assayed drums, having received this quality check, that exceed this limit will be further analyzed to determine the exact amount of fissile material and dispositioned appropriately. Thus, it is considered that "the hazard analysis shows the potential for only significant localized consequences" for determination of the facility hazard category as defined by DOE Order 5480.23. 
It should be noted that a conservative assumption was incorporated in these calculations for the inventory quantity. The assumption is the following.

- It was assumed that $84 \%$ of the TRU released is associated with combustible material, and $16 \%$ is associated with noncombustible material as described in Section 3.1.4.2. This distribution appears to be unique to waste stored in TRUSAF as a $65 \% / 35 \%$ combustible/ noncombustible split is found in most solid waste stored in the burial grounds or in the CWC. This assumption is a major contributor to the large fraction resulting from the ratio of the material at risk to the threshold quantity associated with the combustible material ejected.

\subsection{HAZARD CONTROLS}

\subsubsection{Safety Systems, Structures, and Components}

Chapter 4, "Safety Systems, Structures, and Components, " of DOE-STD-3009-94, Preparation Guide to U.S. Department of Energy Nonreactor Nuclear Facility Safety Analysis Reports, defines safety class systems, structures, and components (SSC) as those whose failure could adversely affect the environment or the health and safety of the public. Based on this definition, all items can be classified as either safety class or nonsafety class. Accordingly, the purpose of safety classification is to ensure that facility SSCs are designed, fabricated, erected, and tested to standards and quality commensurate with the associated hazards and potential consequences. WHC has expanded the safety class concept to address potential consequences to onsite and facility workers and to differentiate between an offsite and onsite environment.

The safety equipment 1 ist for TRUSAF is documented in Transuranic Storage and Assay Facility Safety Equipment List, WHC-SD-SEL-011, Rev. 3 (WHC 1994g). There are no safety class systems with in TRUSAF. No credit for any safetysignificant SSCs has been assumed in the accident analysis for the prevention or mitigation of any accident that could exceed recommended guidelines. There are no SSCs which have been designated safety-significant. Onsite and worker safety is provided by programmatic and procedural controls.

\subsubsection{Administrative Controls/Operational Restrictions}

3.2.2.1 Existing Operational Safety Requirements. There are no existing operational safety requirements for TRUSAF. 
3.2.2.2 Existing Operating, Maintenance, and Surveillance Procedures. The following subset of operating procedures serves to prevent and/or mitigate potential accidents at TRUSAF:

- Respond to Radioactive Material Spills - Emergency, SW-001-310 (WHC 1994h)

- Inspect Solid Waste Storage/Disposal Facilities, SW-040-005 (WHC 1994i)

- Prepare/Complete Radioactive Waste Records, SW-010-003 (WHC 1994j)

- Receive/Assay/Store TRU Waste in 224-T, SW-100-020, (WHC 1994C)

- Package and Transport Radioactive Waste, SW-100-030, (WHC 1994e)

- Overpack 55 Gallon Drums, SW-100-095 (WHC 1994f).

3.2.2.3 New Administrative and Operational Restrictions. DOE Order 5480.22 establishes requirements for the identification and documentation of TSRs. TSRs define acceptable conditions, safe boundaries, and the management or administrative controls necessary to ensure the safe operation of a nuclear facility and reduce the risk to the public and facility workers from uncontrolled releases of radioactive materials.

The four aspects of a TSR are defined below.

- Safety Limits - limits on process variables associated with those primary physical barriers, generally passive, that are necessary for the intended facility function and are required to guard against the uncontrolled release of radioactivity that would result in a dose consequence of $>0.5$ rem to the offsite public.

- Limiting Control Settings - settings on safety systems that control process variables to prevent exceeding safety limits.

- Limiting Conditions for 0peration - the lowest functional capability or performance level of safety-related structures, systems, components, and their support systems required for normal, safe operation based upon maintaining the systems and structures operable or conditions within specified limits that are required to protect the public from radiological consequences that would exceed 0.5 rem.

- Administrative Controls - the provisions relating to organization and management, procedures, recordkeeping, reviews, and audits necessary to ensure safe operation of the facility. Two types of programs are included, general and facility specific.

1. General programs are established to ensure the safe operation of the facility. These programs include procedures, change control, training, reviews and audits, radiation protection, effluent monitoring and criticality safety. 
2. Facility specific programs and provisions are established as being necessary to ensure the safe operation of TRUSAF. These programs include inventory control, access control, and fire protection.

There are no accidents, mitigated or unmitigated, that result in offsite consequences $>0.5 \mathrm{rem}$ in the accident analyses in Section 3.1.4. Safety limits, limiting control settings, or limiting conditions for operations are not required for TRUSAF. There are, however, several administrative controls established to ensure the health and safety of the public is protected and to minimize the risk to workers.

- Organization - lines of authority, responsibility, and communication are established and defined for the highest management levels through intermediate levels to and including all safety and operating organization positions.

- Nuclear Criticality Safety - a program is established, implemented, and maintained to ensure criticality safety consistent with the requirements of applicable DOE orders and WHC-CM-5-36, Chapter 4-29, "Nuclear Criticality Safety Manual."

- TRUSAF Source Term Concentration Control - a program is established, implemented and maintained to ensure radioactive quantities assumed in the hazard categorization and accident analysis, as noted in Chapter 3.0 will not be exceeded. In addition, requirements for waste certification, receipt verification, and packaging are implemented through WHC-EP-0063 (Will is 1994).

These programs and key elements of each are listed as administrative controls in the IOSR document, WHC-SD-WM-TSR-002, TRUSAF Interim Operational Safety Requirements.

\subsubsection{Institutional Safety Programs}

WHC has implemented and is committed to programs for ensuring worker safety and minimization of the impact from releases. Specific details of programs for which credit is taken in the ISB analysis are identified in the IOSRs. SWD has implemented these programs for ensuring worker safety and minimization of the impact from releases in the following WHC controlled manuals:

- WHC-CM-5-34, Solid Waste Disposal Operations Administration

- WHC-CM-5-36, Solid Waste Disposal Internal Requirements

The institutional programs controlled by these documents include but are not limited to the following;

- Company Policies and Charters

- Management Requirements and Procedures

- Industrial Safety

- Industrial Hygiene

- Quality Assurance 
- Emergency Management

- Environmental Protection

- Standard Engineering Practices

- Project Management

- Training for Nuclear Facilities

- As Low As Reasonably Achievable (ALARA)

- Radiation Control

The purpose of these programs is to implement the DOE orders and regulations as they become contractual obligations. Changes to these programs are made by SWD per the change control procedures of WHC-CM-5-34 and WHC-CM-5-36, as necessary, to ensure compliance.

\subsection{SUMMARY}

The potential hazards at TRUSAF are identified and qualitatively evaluated in the preliminary hazard analysis in Section 3.1.2. A subset of potential accidents was selected for quantitative analysis based on both the frequency and consequence considerations and on results of the preliminary hazards analysis. The risks were within the risk-acceptance guidelines for which the SWBG were found acceptable (WHC 1995a). Administrative controls have been developed to mitigate potential hazards and implement established safety programs. The risk of continued operation of TRUSAF is, therefore, acceptable. 


\subsection{CONFIGURATION CONTROLS SYSTEM}

The authorization and safety bases in ISB-004 are founded on the current facility configuration and procedures. Changes to the facility configuration or procedures could impact the authorization and safety bases. A configuration management program is necessary to evaluate such changes. The USQ program, part of the configuration management program, ensures that all changes to the facility and associated procedures are reviewed by trained USQ evaluators. This evaluation ensures that the facility maintains the configuration analyzed in the hazard and accident analysis.

\subsection{CONFIGURATION CONTROL PROCEDURES}

Configuration management is an integrated management program encompassing design control, document control, and change control and is documented in WHC-CM-5-34, Section 2.4, "Configuration Management." The purpose of the configuration management program is to ensure that the facility physical configuration conforms with the reviewed and approved design and safety analysis requirements, and that these requirements are reflected accurately in facility documentation.

Changes in the design/configuration of the facility are addressed in WHC-CM-5-36, Chapter 6-1, "Standard Engineering Practices." This chapter establishes the engineering practices, so uniform methods are in place for all SWD engineering tasks. These practices provide uniform methods for such tasks as design review, configuration control, change control, engineering documentation preparation, and review/approval requirements. All facility modifications will be evaluated using the ISB as the authorization basis, in accordance with WHC-CM-5-36, Chapter 1-3, (Section 5.12). Configuration management for the project work is addressed in WHC-CM-5-36, Chapter 6-2, "Project Management."

\subsection{UNREVIEWED SAFETY QUESTION PROCEDURES}

The subject of USQs is addressed in WHC-CM-5-36, Chapter 1-3, Section 5.12, "Identifying and Resolving Unreviewed Safety Questions." WHC-CM-5-34, Section 1.24 provides a procedure specific to the Solid Waste Disposal operations division. This procedure describes the USQ screening process, evaluation process, review process, record retention, and training requirements for evaluators.

\subsection{QUALITY ASSURANCE PROCEDURES}

The basis and the requirements for WHC-CM-5-36, Chapter 4-2 are out 1 ined in 10 CFR 830.120, "Quality Assurance Requirements," Code of Federal Regulations, as amended. Guidance for Solid Waste Management implementation of all the elements in 10 CFR 830.120 is provided in WHC-CM-5-34. This plan describes the quality assurance program as it relates to the requirements of 
10 CFR 830.120 and the operations conducted within Sol id Waste Management, including engineering, documentation, safety, administration, and radioactive operations. Implementation of this quality assurance program plan supports the objectives of achieving total quality. 


\subsection{REFERENCES}

\subsection{DOCUMENTS}

AIHA, 1991, Emergency Response Planning Guidelines Series, American Industrial Hygiene Association, Cleveland, Ohio.

ARHC0, 1971, Design Criteria Structural Modifications 224-T Building, ARCH0-1929, Atlantic Richfield Hanford Company and Vitro Engineering Corporation, Richland, Washington.

ARHCO, 1972, Design Criteria Supplement No. 2 Additional Modifications to 224-T Building, Atlantic Richfield Hanford Company, Richland, Washington.

Anderson, B. C., 1991, Contact-Handled Transuranic Waste Characterization Based on existing Records, WHC-EP-0225, Rev. 1, Westinghouse Hanford Company, Richland, Washington.

Arnold, P. M., 1986, Characterization of Spent HEPA Filters From Rocky Flats Plant, A0 6629 UNIF, Rockwell International - Rocky Flats Plant, Golden, Colorado.

Carter, R. D., 1989, Packaging, Storage, and Disposal of Solid Waste (55-Gallon Drums, unrestricted H/Pu Only), CSAR 80-021, Westinghouse Hanford Company, Richland, Washington.

Chenault, D. M., 1993, Roof Inspection Results from the 224-T Building (TRUSAF), (Internal Memo DMC-23450-93-008 to B. K. 01sen, February 2) Westinghouse Hanford Company, Richland, Washington.

Clarke, R. K., J. T. Foley, W. F. Hartman, and D. W. Larson, 1976, Severity of Transportation Accidents, SLA-74-0001, Sandia National Laboratory, Albuquerque, New Mexico.

Coast Guard, 1967, Report on the Seismicity of the Hanford Washington Area, United States Coast Guard, Washington, D.C.

Coats, D. W., and R. C. Murray 1984, Natural Phenomena Hazards Modeling Project: Seismic Hazard Models for Department of Energy Sites, UCRL-53582, Lawrence Livermore Nationa1 Laboratory, Livermore, Cal jfornia.

DOE, 1987, Waste Drum Fire Propagation at the Waste Isolation Pilot Plant, DOE/WIPP-87-005, U.S. Department of Energy, Washington, D.C.

EG\&G, 1983, Gas Generation: Year End Report, FY-1983-RHB-387-83, EG\&G Idaho., Idaho Falls, Idaho.

Huerta, M., G. H. Lamoreaux, L. E. Romesberg, H. R. Yoshimura, B. J. Joseph, and R. A. May, 1983, Analysis, Scale Modeling, and Full-Scale Tests of Low-Level Nuclear-Waste-Drum Response to Accident Environments, SAND80-2517, TTC-0315, Sandia National Laboratory, Albuquerque, New Mexico. 
ICRP, 1975, Reference Man: Anatomical, Physiological, and Metabolic Characteristics, Publication 23, International Commission on Radiological Protection, Elmsford, New York.

Mishima, J. and L. C. Schwendiman, 1970, The Amount and Characteristics of Plutonium Made Airborne Under Therma7 Stress, BNWL-SA-3379, Pacific Northwest Laboratory, Richland, Washington.

Nelson, D. C., and E. F. Smith, 1971, Design Criteria Structural Modifications 224-T Building, ARH-1929, Atlantic Richfield Hanford Company, Richland, Washington.

Noweir, M. H., E. A. Pfitzer, and T. F. Hatch, 1973, "Thermal Decomposition of Carbon Tetrachloride Vapors at Its Industrial Threshold Limit

Concentration," American Industrial Hygiene Association Journal, January, pp. 25-37.

NRC, 1988, Nuclear Fuel Cycle Facility Accident Analysis Handbook, NUREG-1320, U.S. Nuclear Regulatory Commission, Washington, D.C.

Resource Conservation and Recovery Act of 1976, 42 USC 6901, et seq.

RL, 1992, 224-T Transuranic Waste Storage and Assay Facility Dangerous Waste Permit Application, DOE/RL-91-51, Rev. 0, U.S. Department of Energy, Richland Operations Office, Richland, Washington.

SDC-4.1, 1993, Standard Architectural-Civil, Design Loads for Facilities, Rev. 12, Hanford Plant Standard, U.S. Department of Energy, Richland Operations Office, Richland, Washington.

Subrahmanyam, V. B., 1990, Radiological Characterization of Discharged Packaged HEPA Filters," (Internal Memo 12715-ASL90-068 to

N. M. Shoemaker, Westinghouse Hanford Company, Richland, Washington.

UBC, 1994, Uniform Building Code, International Conference of Building officials, Whittier, California.

WAC 173-303, 1990, "Dangerous Waste Regulations," Washington Administrative Code, as amended.

WHC, 1987, TRUSAF Hazards Identification \& Evaluation, WHC-SD-WM-SAR-025, Rev. 0, Westinghouse Hanford Company, Richland, Washington.

WHC, 1989, Criticality Prevention Specification, Transuranic Waste Storage in 224-T, CPS-SW-149-00001, Rev. 0, Westinghouse Hanford Company, Richland, Washington.

WHC, 1993, Radioisotopic Characterization of Retrievably Stored Transuranic Waste Containers at the Hanford Site - May 1, 1970 through June 30, 1993, WHC-SD-WM-TI-517, Rev. 0, Westinghouse Hanford Company, Richland, Washington. 
WHC, 1994a, Final Safety Analysis for Contact-Handled Transuranic Waste Drum In Situ Inspection and Vented Drum Retrieval, WHC-SD-WM-SAR-058, Rev. 0, Westinghouse Hanford Company, Richland, Washington.

WHC, 1994b, Load Test of 224-T Building Roof Deck and Support Structure, WHC-SD-GN-TRP-20013, Rev. 0, Westinghouse Hanford Company, Richland, Washington.

WHC, 1994c, Solid Waste Plant Operating Procedure, Receive/Assay/Store TRU Waste in 224-T, SW-100-020, Westinghouse Hanford Company, Richland, Washington.

WHC, 1994d, 224-T TRUSAF Building Upgrade, WHC-SD-WM-ES-288, Rev. 0, Westinghouse Hanford Company, Richland, Washington.

WHC, 1994e, Solid Waste Plant Operating Procedure, Package and Transport Radioactive Waste, SW-100-030, Westinghouse Hanford Company, Richland, Washington.

WHC, 1994f, Overpack 55 Gallon Drums, SW-100-095, Rev. A-0, Westinghouse Hanford Company, Richland, Washington.

WHC, 1994g, Transuranic Storage and Assay Facility Safety Equipment List, WHC-SD-SEL-011, Rev. 3, Westinghouse Hanford Company, Richland, Washington.

WHC, 1994h, Respond to Radioactive Material Spills - Emergency, SW-001-310, Westinghouse Hanford Company, Richland, Washington.

WHC, 1994i, Inspect Solid Waste Storage/Disposal Facilities, SW-040-005, Westinghouse Hanford Company, Richland, Washington.

WHC, 1994j, Prepare/Complete Radioactive Waste Records, SW-010-003, Westinghouse Hanford Company, Richland, Washington.

WHC, 1995a, Solid Waste Burial Grounds Interim Safety Basis, WHC-SD-WM-ISB-002, Rev. 1, West inghouse Hanford Company, Richland, Washington.

WHC, 1995b, Technical Assessment of Workplace Sampling at TRUSAF, WHC-SD-SQA-TA-20015, Rev. 0, Westinghouse Hanford Company, Richland, Washington.

WHC, 1995c, Ana7ytical and Experimental Evaluation of Solid Waste Drum Fire Performance, WHC-SD-WM-TRP-233, Rev. 0, Westinghouse Hanford Company, Richland, Washington.

WHC, 1995d, Solid Waste Information Tracking System Software Design Descriptions, WHC-SD-WM-SWD-009, Rev. 8, Westinghouse Hanford Company, Richland, Washington.

WHC, 1996a, Fire Hazards Analysis of Transuranic Waste Storage and Assay Facility, WHC-SD-WM-FHA-007, Rev. 0, Westinghouse Hanford Company, Richland, Washington. 
WHC, 1996b, Hazard Categorization - Interpretation of DOE Guidance, DOE-STD-1027-92, WHC-SD-WM-RPT-222, Rev. 0, Westinghouse Hanford Company, Richland, Washington.

WHC-IP-0673, Solid Waste Disposal Plant Operating Procedure's Writer's Guide, Rev. 1, Westinghouse Hanford Company, Richland, Washington.

Willis, N. P., 1994, Hanford Site Solid Waste Acceptance Criteria, WHC-EP-0063, Westinghouse Hanford Company, Richland, Washington.

WIPP, 1989, TRU Waste Certification Compliance Requirements For Acceptance of Newly-Generated Contact-Handled Waste to be Shipped to the Waste Isolation Pilot Plant, WIPP-DOE-120, Westinghouse Electric Corporation, Carlsbad, New Mexico.

10 CFR 830.120, "Quality Assurance Requirements," Code of Federa7 Regulations, as amended.

49 CFR 173, "Shippers-General Requirements for Shipments and Packaging," Code of Federal Regulations, as amended.

\subsection{U.S. DEPARTMENT OF ENERGY ORDERS}

DOE Order 5480.6, Safety of Department of Energy-Owned Nuclear Reactors, U.S. Department of Energy, Washington, D.C.

DOE Order 5480.2A, Radioactive Waste Management, U.S. Department of Energy, Washington, D.C.

DOE Order 5480.21, Unreviewed Safety Questions, U.S. Department of Energy, Washington, D.C.

D0E Order 5480.22, Technical Safety Requirements, U.S. Department of Energy, Washington, D.C.

DOE Order 5480.23, Nuclear Safety Analysis Reports, U.S. Department of Energy, Washington, D.C.

DOE-STD-1027-92, Hazard Categorization and Accident Analysis Techniques for Compliance with DOE Order 5480.23, Nuclear Safety Analysis Reports, U.S. Department of Energy, Washington, D.C.

DOE-STD-3009-94, Preparation Guide for U.S. Department of Energy Nonreactor Nuclear Facility Safety Analysis Report, U.S. Department of Energy, Washington, D.C.

DOE-HDBK-3010-94, Airborne Release Fractions Rates/Rates and Respirable Fractions for Nonreactor Nuclear Facilities, DOE-HDBK-3010-94, U.S. Department of Energy, Washington, D.C. 


\subsection{CONTROLLEO MANUALS}

HSRCM-1, Hanford Site Radiological Control Manual, Westinghouse Hanford Company, Richland, Washington.

WHC-CM-5-34, Solid Waste Disposal Operations Administration, Westinghouse Hanford Company, Richland, Washington.

WHC-CM-5-36, Solid Waste Disposa7 Internal Requirements, Westinghouse Hanford Company, Richland, Washington.

WHC-IP-1043, WHC Occupational ALARA Program, Westinghouse Hanford Company, Richland, Washington. 
WHC-SD-WM-ISB-004 REV 1

This page intentionally left blank.

5-6 
WHC-SD-WM-ISB-004 REV 1

APPENDIX A

RADIOLOGICAL CHARACTERIZATION

A-1 
WHC-SD-WM-ISB-004 REV 1

This page intentionally left blank. 
When analyzing a drum accident in a population of drums that contain various quantities of transuranic (TRU) waste, the following methodology will be used to estimate the TRU inventory of the drums involved in the accident:

- For a single drum accident, the maximum postulated TRU drum (400 g TRU) in the population

- For an accident involving two drums, the maximum TRU drum $(400 \mathrm{~g}$ TRU) and the 95 percentile drum (only $5 \%$ of the total drum population would exceed the TRU loading of these drums)

- For an accident involving more than 2 drums, but less than 30 , one maximum TRU drum and the 95 percentile drums

- For an accident involving more than 30 drums, one maximum TRU drum and the average of the drum population.

This method is consistent with that outlined in Radiological and Chemical Source Terms for Solid Waste Operations Complex, WHC-SD-W306-TI-001, Rev. 0 (WHC 1993), except for one deviation that uses a more conservative approach. The methodology in WHC-SD-W306-TI-001 uses the 95 percentile drum for both drums in a two-drum accident.; however, it is more conservative to use the maximum drum and the 95 percentile drum in the two-drum accident.

The radiological information for the 208-L (55-gal) drums at the Transuranic Waste Storage and Assay Facility (TRUSAF) was obtained from the Solid Waste Information Tracking System (SWITS) database (WHC 1995d) and is shown in Table A-1 and Table A-2. Although other TRU elements may be present at the TRUSAF, plutonium is the most limiting. 
Table A-1. Plutonium Distribution.

\begin{tabular}{|l|c|r|c|}
\hline \multicolumn{1}{|c|}{ Range Pu (g) } & \# of drums & $\begin{array}{c}\text { Cumulative \# } \\
\text { of drums }\end{array}$ & $\begin{array}{c}\text { Cumulative \% of } \\
\text { total }\end{array}$ \\
\hline$r<0.1$ & 79 & 79 & 7.1 \\
\hline $0.1 \leq r<1.0$ & 78 & 157 & 14.2 \\
\hline $1.0 \leq r<10$ & 229 & 386 & 34.9 \\
\hline $10 \leq r<50$ & 334 & 720 & 65.2 \\
\hline $50 \leq r<75$ & 106 & 826 & 74.8 \\
\hline $75 \leq r<100$ & 100 & 926 & 83.8 \\
\hline $100 \leq r<150$ & 127 & 1,053 & 95.3 \\
\hline $150 \leq r<200$ & 52 & 1,105 & 100.0 \\
\hline $200 \leq r$ & 0 & 1,105 & 100.0 \\
\hline 95 th $\%=150 \mathrm{~g}$ & & & \\
\hline
\end{tabular}

Boothe 1993.

$r=g \mathrm{Pu}$.

Table A-2. Radiological Characterization.

\begin{tabular}{|l|c|c|}
\hline \multicolumn{1}{|c|}{ Drum content } & Plutonium (g) & Total beta/gamma (Ci) \\
\hline Maximum & 194.0 & 25.0 \\
\hline Minimum & 0.0001 & 0.0 \\
\hline Average & 45.7 & 0.19 \\
\hline Boothe 1993
\end{tabular}

\section{REFERENCES}

Boothe, G. F., 1993, Radiological and Chemical Source Terms for Solid Waste Operations Complex, WHC-SD-W306-TI-001, Rev. 0, Westinghouse Hanford Company, Richland, Washington.

WHC, 1995d, Solid Waste Information Tracking System Software Design Descriptions, WHC-SD-WM-SWD-009, Rev. 8, Westinghouse Hanford Company, Richland, Washington. 
WHC-SD-WM-ISB-004 REV 1

APPENDIX B

CONSEQUENCE CALCULATION METHOD

B-1 
WHC-SD-WM-ISB-004 REV 1

This page intentionally left blank. 
The doses resulting from the inhalation of radioactive materials are calculated in accordance with the following equation:

$$
\text { Dose }(\text { rem })=S T(C i) \cdot \frac{X}{Q}\left(\mathrm{~s} / \mathrm{m}^{3}\right) \cdot C(\mathrm{rem} / \mathrm{Ci}) \cdot R\left(\mathrm{~m}^{3} / \mathrm{s}\right)
$$

where

ST $=$ quantity plutonium released per source term

$x / Q=$ atmospheric dispersion coefficient

$C=$ plutonium dose conversion factor

$\mathrm{R}=$ breathing rate.

The source term is specific to the accident scenario. The development of the source term is presented in detail in Section 3.1.3.1.2.

The atmospheric dispersion coefficient $(X / Q)$ refers to the concentration of airborne contamination. It is the ratio of contaminant concentration at a specific receptor location to contaminant release rate.

A $99.5 \% \times / Q$ was calculated for both the maximum onsite and offsite boundary receptor as documented in Supporting Calculations for TRUSAF Interim Safety Basis (Hey 1994a, 1994b, and 1995). Note that the nearest onsite receptor distance is the same distance that is used for the T Plant facility, $500 \mathrm{~m}$ south-south-east. Results are provided in Table B-1.

Table B-1. Bounding Maximum Sector Atmospheric Dispersion Coefficients for Use in $224-T$ ISB $\left(\mathrm{s} / \mathrm{m}^{3}\right)$.

\begin{tabular}{|l|l|c|}
\hline \multicolumn{1}{|c|}{$\begin{array}{c}\text { Receptor/scenario } \\
\text { descriptor }\end{array}$} & \multicolumn{1}{|c|}{$\begin{array}{c}\text { Sector and } \\
\text { distance }\end{array}$} & X/Q \\
\hline $\begin{array}{l}\text { Onsite ground level } \\
\text { release w/building wake }\end{array}$ & SSE at $500 \mathrm{~m}$ & $5.94 \mathrm{E}-4$ \\
\hline $\begin{array}{l}\text { Site boundary ground level } \\
\text { release w/building wake }\end{array}$ & W at $13,110 \mathrm{~m}$ & $1.48 \mathrm{E}-05$ \\
\hline $\begin{array}{l}\text { Onsite buoyant plume } \\
\text { release w/building wake } \\
\text { and plume trapping }\end{array}$ & SSE at $500 \mathrm{~m}$ & $3.14 \mathrm{E}-05$ \\
\hline $\begin{array}{l}\text { Site boundary buoyant } \\
\text { plume release w/building } \\
\text { wake and plume trapping }\end{array}$ & E at $22,570 \mathrm{~m}$ & $3.75 \mathrm{E}-06$ \\
\hline
\end{tabular}


Dose conversion factors were calculated for inhalation of $1 \mathrm{Ci}$ each of respirable ${ }^{90} \mathrm{Sr},{ }^{137} \mathrm{Cs}$, mixed fission products, and nominal $12 \%{ }^{240} \mathrm{Pu}$ aged 20 years at the release point (Hey 1994). The daughter products of ${ }^{90} \mathrm{Sr}$, ${ }^{106} \mathrm{Ru},{ }^{137} \mathrm{Cs}$, and ${ }^{144} \mathrm{Ce}$ were assumed to be present at their equilibrium values. Effective dose equivalents (EDEs) are calculated, as well as committed doses for the lung, small intestine, and bone surface organs because each is a maximum organ depending upon the radionuclide inventory. Results are provided in Table B-2. Submersion doses were also calculated, but are negligible in comparison to the inhalation dose pathway.

Table B-2. Dose per Curie Inhaled (rem/Ci).

\begin{tabular}{|l|c|c|c|c|}
\hline \multirow{2}{*}{ Source radionuclide } & \multirow{2}{*}{ EDE } & \multicolumn{3}{|c|}{ Committed organ dose } \\
\cline { 3 - 5 } & & Lung & $\begin{array}{c}\text { Small } \\
\text { intestine }\end{array}$ & $\begin{array}{c}\text { Bone } \\
\text { surface }\end{array}$ \\
\hline${ }^{90} \mathrm{Sr}$ & $2.1 \mathrm{E}+05$ & $4.1 \mathrm{E}+04$ & $5.7 \mathrm{E}+03$ & $2.4 \mathrm{E}+06$ \\
\hline${ }^{137} \mathrm{Cs}$ & $3.0 \mathrm{E}+04$ & $3.3 \mathrm{E}+04$ & $3.4 \mathrm{E}+04$ & $3.0 \mathrm{E}+04$ \\
\hline Mixed fission products & $2.1 \mathrm{E}+05$ & $1.4 \mathrm{E}+06$ & $8.9 \mathrm{E}+03$ & $3.2 \mathrm{E}+05$ \\
\hline $\begin{array}{l}\text { Nominal 12\% plutonium aged } \\
20 \text { years }\end{array}$ & $6.0 \mathrm{E}+07$ & $7.9 \mathrm{E}+06$ & $1.6 \mathrm{E}+03$ & $1.1 \mathrm{E}+09$ \\
\hline
\end{tabular}

*One gram plutonium is equivalent to $1.29 \mathrm{Ci}$ for this isotopic mixture. $E D E$ = effective dose equivalent.

The breathing rate is taken from Reference Man: Anatomical, Physiological, and Metabolic Characteristics (ICRP 1975). The breathing rate for a standard person receiving an acute dose is $3.3 \times 10^{-4} \mathrm{~m}^{3} / \mathrm{s}$. Inhalation is by far the most significant, unavoidable, and likely pathway for human exposure. Although ingestion can cause a dose in excess of that committed through inhalation, the ingestion pathway can be avoided through interdiction of food stuffs in the event of an accident. The ground shine and plume submersion pathways can, for all practical purposes, be ignored for releases of plutonium.

Table B-2 1ists values applicable for the soluble form of plutonium. The following values (applied to fire/explosion scenarios) are for insoluble plutonium:

- $\quad E D E=4.3 \quad E+07$

- Bone surface $=4.2 \mathrm{E}+08$.

Radiological doses were calculated for the total isotopic inventory of the 224-T Building process cells (Hey 1994b). These doses were derived from the total estimated isotopic inventory of the 224-T Building process cells found in 224-T TRUSAF Building Upgrade, WHC-SD-WM-ES-288, ReV. O (WHC 1994). To ensure conservatism in the health hazard estimate, the ${ }^{239} \mathrm{Pu}$ activity was doubled in the dose estimate. This was done on the basis that approximately half of the inhalation dose from nominal $12 \%$ plutonium is results from the isotopes ${ }^{238} \mathrm{Pu},{ }^{240} \mathrm{Pu}$, and ${ }^{241} \mathrm{Pu}$, which, although present, are not reported by WHC-SD-WM-ES-288. The daughter products of ${ }^{90} \mathrm{Sr}$ and ${ }^{137} \mathrm{Cs}$ were assumed to be present in their equilibrium values. EDEs are calculated as well as committed 
dose for bone surface, which is the maximally effected organ. Submersion doses are also included but are negligible in comparison to the inhalation dose pathway. The inventory is respirable material and is given in rems which were calculated from curies without the breathing rate considered. Results are provided in Table B-3.

Table B-3. Dose Potential for 224-T Process Cell Inventory Inhaled (rem).

\begin{tabular}{|c|c|c|}
\hline Source radionuclide & EDE & $\begin{array}{c}\text { Committed organ dose } \\
\text { (bone surface) }\end{array}$ \\
\hline Total 224-T Building process cells & $2.9 \mathrm{E}+10$ & $5.4 \mathrm{E}+11$ \\
\hline
\end{tabular}

$E D E=$ effective dose equivalent.

The relative significance of fission products to the total dose can be observed by calculating the individual components of the total dose. The radiological characterization information of Appendix $A$ is used as a sample to make the following sample calculation. The fission products are modeled by assuming $50 \%$ of the isotopes are ${ }^{90} \mathrm{Sr}$ and the remaining $50 \%$ of the isotopes are ${ }^{137} \mathrm{Cs}$.

The following calculations, for an onsite ground level release with building wake, determine the EDE equivalent using average concentrations of plutonium and fission products, taken from the average drum inventory distribution depicted in Appendix A. See Table A-2. The inventory is respirable material given in curies. Determination of potential dose consequences to an individual would be based on this total inventory multiplied by the breathing rate and the appropriate dispersion factor.

$$
\begin{aligned}
& \text { For }{ }^{90} \mathrm{Sr} \\
& S T=(0.19 \mathrm{Ci} * 50 \%)=9.5 \mathrm{E}-02 \mathrm{Ci} \text { (Table A-2, Total } \mathrm{B} / \mathrm{Y} \text {, Average) } \\
& (X / Q)=5.94 E-04 \mathrm{~s} / \mathrm{m}^{3} \text { (Table B-1, Ons ite Ground Level Release) } \\
& C=2.1 \mathrm{E}+05(\mathrm{rem} / \mathrm{Ci}) \quad\left(\text { Table } \mathrm{B}-2,{ }^{90} \mathrm{Sr}, \mathrm{EDE}\right) \\
& R=3.3 E-04\left(\mathrm{~m}^{3} / \mathrm{s}\right) \quad \text { (ICRP 1975) } \\
& \text { Dose }(\text { rem })=S T(C i) \cdot\left(\frac{x}{Q}\right)\left(s / m^{3}\right) \cdot C(\text { rem } / C i) \cdot R\left(m^{3} / s\right) \\
& =(9.5 \mathrm{E}-02 \mathrm{Ci}) \cdot\left(5.94 \mathrm{E}-04 \mathrm{~s} / \mathrm{m}^{3}\right) \cdot(2.1 \mathrm{E}+05 \mathrm{rem} / \mathrm{Ci}) \cdot\left(3.3 \mathrm{E}-04 \mathrm{~m}^{3} / \mathrm{s}\right) \\
& =3.91 \mathrm{E}-03 \mathrm{rem} \text {. }
\end{aligned}
$$


For ${ }^{137} \mathrm{Cs}$

$$
\begin{aligned}
\mathrm{ST} & =(0.19 \mathrm{Ci} * 50 \%)=9.5 \mathrm{E}-02 \mathrm{Ci} \text { (Table A-2, Total B/v, Average) } \\
(\mathrm{X} / \mathrm{Q}) & =5.94 \mathrm{E}-04 \mathrm{~s} / \mathrm{m}^{3} \text { (Table B-1, Onsite Ground Level Release) } \\
\mathrm{C} & =3.0 \mathrm{E}+04(\mathrm{rem} / \mathrm{Ci}) \quad\left(\text { Table B-2, }{ }^{37} \mathrm{CS}, \mathrm{EDE}\right) \\
\mathrm{R} & =3.3 \mathrm{E}-04\left(\mathrm{~m}^{3} / \mathrm{s}\right) \quad(\mathrm{ICRP} 1975) \\
\text { Dose }(\mathrm{rem}) & =\mathrm{ST}(\mathrm{Ci}) \cdot\left[\frac{X}{Q}\right)\left(\mathrm{s} / \mathrm{m}^{3}\right) \cdot \mathrm{C}(\mathrm{rem} / \mathrm{Ci}) \cdot \mathrm{R}\left(\mathrm{m}^{3} / \mathrm{s}\right) \\
& =(9.5 \mathrm{E}-02 \mathrm{Ci}) \cdot\left(5.94 \mathrm{E}-04 \mathrm{~s} / \mathrm{m}^{3}\right) \cdot(3.0 \mathrm{E}+04 \mathrm{rem} / \mathrm{Ci}) \cdot\left(3.3 \mathrm{E}-04 \mathrm{~m}^{3} / \mathrm{s}\right) \\
& =5.59 \mathrm{E}-04 \mathrm{rem} .
\end{aligned}
$$

For plutonium

$$
\begin{aligned}
\mathrm{ST} & =(45.66 \mathrm{~g} * 1.29 \mathrm{Ci} / \mathrm{g})=58.90 \mathrm{Ci} \text { (Table A-2, Plutonium, Average) } \\
(\mathrm{X} / \mathrm{Q}) & =5.94 \mathrm{E}-04 \mathrm{~s} / \mathrm{m}^{3} \quad \text { (Table B-1, Ons ite Ground Level Release) } \\
\mathrm{C} & =6.0 \mathrm{E}+07(\mathrm{rem} / \mathrm{Ci}) \quad(\text { Tab7e B-2, Pu, EDE) } \\
\mathrm{R} & =3.3 \mathrm{E}-04\left(\mathrm{~m}^{3} / \mathrm{s}\right) \quad \text { (ICRP 1975) }
\end{aligned}
$$

$$
\begin{aligned}
\text { Dose }(\text { rem }) & =S T(C i) \cdot\left[\frac{X}{Q}\right)\left(\mathrm{s} / \mathrm{m}^{3}\right) \cdot C(\mathrm{rem} / \mathrm{Ci}) \cdot \mathrm{R}\left(\mathrm{m}^{3} / \mathrm{s}\right) \\
& =(5.89 \mathrm{E}+01 \mathrm{Ci}) \cdot\left(5.94 \mathrm{E}-04 \mathrm{~s} / \mathrm{m}^{3}\right) \cdot(6.0 \mathrm{E}+07 \mathrm{rem} / \mathrm{Ci}) \cdot\left(3.3 \mathrm{E}-04 \mathrm{~m}^{3} / \mathrm{s}\right) \\
& =6.93 \mathrm{E}+02 \mathrm{rem} .
\end{aligned}
$$

With these individual components of the total dose, the fraction of the dose from the fission products can be determined as

$$
\begin{aligned}
\text { Ratio } & =\left(\frac{\text { Dose } S r-90+C s-137}{\text { Dose Sr-90+Cs-137+plutonium }}\right) \\
& =\left(\frac{3.91 \mathrm{E}-03 \mathrm{rem}+5.59 \mathrm{E}-04 \mathrm{rem}}{3.91 \mathrm{E}-03 \mathrm{rem}+5.59 \mathrm{E}-04 \mathrm{rem}+6.93 \mathrm{E}+02 \mathrm{rem}}\right) \\
& =6.45 \mathrm{E}-06 .
\end{aligned}
$$

The contribution of ${ }^{90} \mathrm{Sr}$ and ${ }^{137} \mathrm{Cs}$ to the total effective dose equivalent is less than 0.001 percent. 


\section{REFERENCES}

Hey, B. E., 1994a, Supporting Calculations for TRUSAF Interim Safety Basis, (Internal Memo BEH-8D150-94-001 to M.R. Greutman, May 27), Westinghouse Hanford Company, Richland, Washington.

Hey, B. E., 1994b, Supporting Calculations for TRUSAF Interim Safety Basis, (Internal Memo BEH-8D150-94-005 to M. R. Greutman, November 18) Westinghouse Hanford Company, Richland, Washington.

Hey, B. E., 1995, Supporting Calculations for TRUSAF Interim Safety Basis, (Internal Memo BEH-8M400-95-003 to A.L. Bonner, March 27) Westinghouse Hanford Company, Richland, Washington.

ICRP, 1975, Reference Man: Anatomical, Physiological, and Metabolic Characteristics, Publication 23, International Commission on Radiological Protection, Elmsford, New York.

WHC, 1994, 224-T TRUSAF Building Upgrade, WHC-SD-WM-ES-288 Rev. 0, Westinghouse Hanford Company, Richland, Washington. 
WHC-SD-WM-ISB-004 REV 1

This page intentionally left blank. 
WHC-SD-WM-ISB-004 REV 1

APPENDIX C

COMBUSTIBLE CHARACTERIZATION

C-1 
WHC-SD-WM-ISB-004 REV 1

This page intentionally left blank. 
Information on the combustible loadings of 55-gal drums at the Transuranic Waste Storage and Assay Facility (TRUSAF) was obtained from the Solid Waste Information Tracking System (SWITS) database (WHC 1995d). The data provided the average volume of combustible waste types. The drum waste total weight was calculated by multiplying the vol\% by the theoretical density and by the volume of the drum $\left(0.208 \mathrm{~m}^{3}\right)$. This resulted in values that were far above the actual drum weights. Joyce's (1993) internal memorandum, SWBG FHA Combustible Loadings for TRU 55-Gallon Drums, on combustible loadings for TRU 208-L (55-gal) drums indicates that this over estimation is because of a void volume of $83 \%$. This reduced density is consistent with the volume reduction found for $10 \mathrm{w}-1$ evel waste compactors located in the 300 and 400 Areas. The last column of the table is derived by assuming a drum contains $100 \%$ combustible loadings in the same proportions as the average drum. This results is a combustible loading of $41.1 \mathrm{~kg}$. This is comparable with a value of $41.7 \mathrm{~kg}$ of combustible material for a drum containing $100 \%$ combustible loadings as calculated in Joyce (1993). The results are summarized in Table C-1.

Table C-1. Combustible Characteristics for Drums at Transuranic Waste Storage and Assay Facility.

\begin{tabular}{|l|c|r|r|c|c|}
\hline Waste type & $\begin{array}{c}\text { Drum } \\
\text { percentage }\end{array}$ & $\begin{array}{c}\text { Density } \\
\left(\mathrm{kg} / \mathrm{m}^{3}\right)\end{array}$ & $\begin{array}{c}\text { Weight } \\
(\mathrm{kg})\end{array}$ & $\begin{array}{c}\text { Weight at 83\% } \\
\text { void volume } \\
(\mathrm{kg})\end{array}$ & $\begin{array}{c}\text { Weight for 100\% } \\
\text { combust ible } \\
(\mathrm{kg})\end{array}$ \\
\hline Wood & 7.06 & 513 & 7.5 & 1.3 & 1.5 \\
\hline Rubber & 18.57 & 958 & 37.0 & 6.3 & 7.5 \\
\hline Plastic & 33.72 & 1,406 & 98.6 & 16.8 & 20.0 \\
\hline Paper & 13.85 & 929 & 26.8 & 4.5 & 5.4 \\
\hline Cloth & 10.60 & 1,491 & 32.9 & 5.6 & 6.7 \\
\hline Tota7s & 83.80 & -- & 202.8 & 34.5 & 41.1 \\
\hline
\end{tabular}

\section{REFERENCES}

Joyce, J. P., 1993, SWBG FHA Combustible Loadings for TRU 55-Gallon Drums, (Internal Memo JPJ-29540-93-001 to C.B. Evans) Westinghouse Hanford Company, Richland, Washington.

WHC, 1995d, Solid Waste Information Tracking System Software Design Descriptions, WHC-SD-WM-SWD-009, Rev. 8, Westinghouse Hanford Company, Richland, Washington. 
WHC-SD-WM-ISB-004 REV I

This page intentionally left blank. 
WHC-SD-WM-ISB-004 REV 1

APPENDIX D

PROCESS CELLS DESCRIPTION 
WHC-SD-WM-ISB-004 REV 1

This page intentionally left blank. 
The 224-T Building is divided into two sections by a $0.3-\mathrm{m}(1-\mathrm{ft})$ thick, seismically-qualified concrete wall that bisects the building along its length in a southwest to northeast direction. The northwest section of the building is used for the Transuranic Waste Storage and Assay Facility (TRUSAF). The southeast section consists of six cells and an open canyon type space above the cells. The cells presently contain contaminated process equipment, tanks, and piping.

The equipment and radiological characteristics of the 224-T cell area is unknown. However for estimating purposes, it is assumed that because of the similarity of the 224-T and 224-B Buildings, the radiological data contained in the 224-B report from (Gould 1985) can be used as a bas is to evaluate the 224-T Building in this report. The estimated isotopic inventory in the 224-T process cells is presented in Table D-1.

Table D-1. Estimated Isotopic Inventory in the 224-T Process Cells.

\begin{tabular}{|c|c|c|c|c|c|}
\hline \multicolumn{7}{|c|}{ Isotopic inventory (Ci) } \\
\hline $\mathrm{Ce} 11$ & ${ }^{241} \mathrm{Am}$ & ${ }^{239} \mathrm{Pu}$ & ${ }^{137} \mathrm{Cs}$ & ${ }^{90} \mathrm{Sr}$ & ${ }^{60} \mathrm{Co}$ \\
\hline$A$ & $5.9 \mathrm{E}-02$ & $7.7 \mathrm{E}-01$ & $1.6 \mathrm{E}-02$ & $3.6 \mathrm{E}-02$ & $6.0 \mathrm{E}-03$ \\
\hline$B$ & $8.8 \mathrm{E}-02$ & $1.2 \mathrm{E}+00$ & $8.2 \mathrm{E}-03$ & $6.0 \mathrm{E}-03$ & $3.0 \mathrm{E}-03$ \\
\hline$C$ & $2.0 \mathrm{E}-01$ & $2.6 \mathrm{E}+00$ & $2.7 \mathrm{E}-01$ & $1.9 \mathrm{E}+01$ & $3.6 \mathrm{E}+00$ \\
\hline$D$ & $3.5 \mathrm{E}+00$ & $8.6 \mathrm{E}+00$ & $1.0 \mathrm{E}-02$ & $1.2 \mathrm{E}-01$ & $1.5 \mathrm{E}-02$ \\
\hline$E$ & $6.7 \mathrm{E}-02$ & $8.8 \mathrm{E}-01$ & $4.4 \mathrm{E}-02$ & $5.4 \mathrm{E}-02$ & $6.0 \mathrm{E}-03$ \\
\hline F & $1.3 \mathrm{E}+00$ & $1.7 \mathrm{E}+01$ & $6.6 \mathrm{E}-01$ & $1.3 \mathrm{E}+00$ & $<5.0 \mathrm{E}-03$ \\
\hline Loadout hood & $6.8 \mathrm{E}-04$ & $8.9 \mathrm{E}-03$ & $1.9 \mathrm{E}-08$ & -- & -- \\
\hline Total & $5.2 \mathrm{E}+00$ & $3.1 \mathrm{E}+01$ & $1.0 \mathrm{E}+00$ & $2.1 \mathrm{E}+01$ & $3.6 \mathrm{E}+00$ \\
\hline
\end{tabular}

The processing portion of the building consists of six cells (A through F). Cel1s A through E are three stories high (122 $\mathrm{m}$ [40 ft]) and are separated from each other by $4.6-\mathrm{m}(15-\mathrm{ft}) \mathrm{high}, 20.3-\mathrm{cm}$ (8-in.) thick concrete walls. Each of these cells is $\approx 7.6$ by $8.5 \mathrm{~m}$ ( 25 by $28 \mathrm{ft}$ ). Cells $\mathrm{A}$, $B, D$, and $E$ are similar in equipment and configuration. On the first floor of each cel1, there are two $2.7-\mathrm{m}(9-\mathrm{ft})$ diameter by $2.7-\mathrm{m}(9-\mathrm{ft})$ high tanks and one $1.4-\mathrm{m}(4.5-\mathrm{ft})$ diameter by $2.1-\mathrm{m}(7-\mathrm{ft})$ high tank. B cell has an additional tank with smaller dimensions. Some of the tanks are equipped with agitators and motors. The $A, B, D$, and $E$ cells al so have a 3.0 by $3.7-m$ (10 by 12-ft) operating deck at the second-floor level. A 101.6-cm (40-in.) centrifuge was located on each of these operating decks. After the building was deactivated, the E-cell centrifuge was removed from the operating deck and placed on the cell floor. A temporary plank and plywood deck has been built over $E$ cell $1.5 \mathrm{~m}(5 \mathrm{ft})$ above the second-floor level. 
C cell differs from the other cells in structure and arrangement. Approximately one-half of the cell is a deep cell - the floor is $5.8 \mathrm{~m}$ (19 ft) below the first-floor level. Vessels in the deep cell include two 1.4-m (4.5-ft) diameter by $2.1-\mathrm{m}(7-\mathrm{ft})$ high tanks and one $2.7-\mathrm{m}(9-\mathrm{ft})$ diameter by $2.7-\mathrm{m}(9-\mathrm{ft}) \mathrm{high}$ tank. A 1.7 by $3.4-\mathrm{m}(5.5$ by $11-\mathrm{ft})$ high pipe tunnel extends $10.4 \mathrm{~m}(34 \mathrm{ft})$ from the deep cell beneath the first-floor offices to a pipe encasement. The piping in this tunnel and the encasement were used for transferring solutions between the 221-T Building (the separations facility) and the 224-T Building (the concentration facility). A single 2.7-m diameter by $2.7-\mathrm{m}$ high tank sits on the first-floor level of $[$ cell.

There is a ground-level personnel access door into each of the five cells from outside. Additionally, a $3.7-$ by $3.7-\mathrm{m}-(12$ by $12-\mathrm{ft}-$ ) high equipment access door is located in the top portion of the outside wall of $E$ cell.

The 15.4 by $7.6-\mathrm{m}$ ( 50.5 by $25-\mathrm{ft}$ ) high $F$ cell is separated from the other cells by a concrete wal1. One-quarter of $F$ cell is a 3.9 by $7.6-\mathrm{m}$ (12.7 by $25-\mathrm{ft})$ centrifuge deck that is elevated $2.17 \mathrm{~m}(7 \mathrm{ft})$ above the remainder of the cell floor. The $F$ cell can be entered through doors from the loadout area and the outside.

There are two $66-\mathrm{cm}$ (26-in.) centrifuges on the elevated operating deck. The first-floor level has four vessels that are $1.2 \mathrm{~m}(4 \mathrm{ft})$ in diameter by $1.5 \mathrm{~m}(5 \mathrm{ft}) \mathrm{high}$. Additional equipment includes a small centrifuge $(\approx 30.5 \mathrm{~cm}$ [12 in.] in diameter) and two small vessels $(\approx 0.5$ by $0.6 \mathrm{~m}[1.5$ by $2 \mathrm{ft}]$ high). A scale and agitator have been stored in $F$ cell.

The detailed characterization measurements of the 224-B hot cells was used to develop an estimate of the radiological inventory. The nontransuranic radionuclide inventory is $25 \mathrm{Ci}$, consisting of the following:

- $1.0 \mathrm{Cj}$ of ${ }^{137} \mathrm{Cs}$

- $21 \mathrm{Ci}$ of ${ }^{90} \mathrm{Sr}$

- $3.6 \mathrm{Ci}$ of ${ }^{60} \mathrm{Co}$.

The transuranic inventory is $36 \mathrm{Ci}$, consisting of the following:

- $\quad 5.2 \mathrm{Ci}$ of ${ }^{249} \mathrm{Am}$

\section{REFERENCES}

Gould, J. I., 1985, SD-DD-TRP-002, Rev. 0, Rockwe11 Hanford Operations, Rich1 and, Washington. 
APPENDIX E

\section{SAFETY EVALUATION REPORT}

Safety Evaluation Report (SER) for the Transuranic Waste Storage and Assay Facility Interim Safety Basis

(WHC-SD-WM-ISB-004) and Interim Operationa 1

Safety Requirements (WHC-SD-WM-TSR-002)

\section{Prepared by TRUSAF ISB Review Team}

Theo Martin, Jr. Rudy Guercia

Paul Macbeth Michael Collopy

Morris Moser
DOE/RL Waste Programs Division DOE/RL Waste Programs Division Dames \& Moore/Mactec GSSC Support DOE/RL Quality, Safety \& Health DOE/RL Waste Operations Division 
WHC-SD-WM-ISB-004 REV 1

This page intentionally left blank. 


\section{Department of Energy \\ Fichland Operations Office \\ P.O. Box 550 \\ Richland, Washington 99352 \\ Da 201996}

96-SWT-278

Mr. H. J. Hatch, President

Fiuor Daniel Hanford, Inc.

Rich] and, Washington

Dear Mr. Hatch:

CONTRACT NUMBER DE-ACO6-96RL13200: AUTHORIZATION BASIS FOR TRANSURANIC WASTE STORAGE AND ASSAY FACILITY (TRUSAF)

Reference: Letter, P. L. Hapke, WHC, to T. K. Teynor, RL, "Transuranic Storage and Assay Facility Interim Safety Basis and Interin Operational Safety Requirements," 9653362, dated July 30, 1996.

The RL Waste Programs Division (WPD) received the TRUSAF Interim Safety Basis (ISB) and Interin Operational Safety Requirements (IOSR) on July 30, 1996, transmitted with the referenced letter, and RL has now completed its technical review. The attached version of the ISB and IOSR incorporate the resolution to comments generated in the final review process, and are now acceptable and hereby approved as indicated in the attached Safety Evaluation Report (SER).

The SER documents the basis for RL approval and is to be considered an explicit part of the authorization basis for operations at TRUSAF, and distributed with all copies of the ISB and IOSR. RL expects that this ISB will be fully implemented as the safety authorization basis for TRUSAF operations within 60 days of the date of this approval letter.

If you have any questions on this topic, you may contact me or your staff may contact either Thomas K. Teynor, RL WPD Director, on 376-1366 or Rudy Guercia, Sol id Waste Program Manager, on 376-5494.

WPD:TM

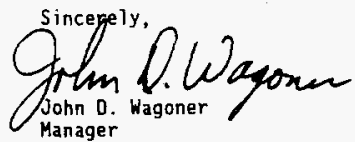

Attachments :

(1) TRUSAF ISB

(2) TRUSAF IOSR

(3) TRUSAF ISB/IOSR SER

cc w/attach:

E. S. Aromi, RFSH

R. J. Girior, RFSH

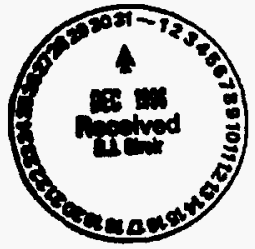


WHC-SD-WM-ISB-004 REV I

This page intentionally left blank.

$E-4$ 


\section{EXECUTIVE SUMMARY}

This Safety Evaluation Report (SER) documents DOE approval of the Transuranic Waste Storage and Assay Facility (TRUSAF) Interim Safety Basis (ISB) (WHC-SD-WM-ISB-004, Rev. 0-A) and Interim Operational Safety Requirements (IOSR) (WHC-SD-WM-TSR-002, Rev. 0). Preparation of this SER is the culmination of an extensive review of the TRUSAF ISB and its supporting documentation by personnel and support contractors from DOE/RL's Waste Programs, Quality, Safety and Health, and Waste Operations Divisions. All pertinent comments generated during this review have been resolved with issuance of this SER. The comments and resolutions based on the September 1995 and June 1996 drafts of the ISB and March and June 1996 drafts of the IOSR are included in Attachment 1.

DOE approval of the TRUSAF ISB and supporting documents is based on resolution of the comments as documented in Attachment 1. Specifically, the IOSR has been revised to list the administrative controls required to ensure that TRUSAF operations remain within the analyzed safety envelope. The existing Criticality Prevention Specifications are included in the safety basis. The basis for acceptable levels of risk from TRUSAF operations is compliance with the waste acceptance criteria established in this ISB and IOSR, as currently implemented in the Hanford Site Solid Waste Acceptance Criteria (WHC-EP-0063). The inventory, concentration, and packaging requirements and controls as implemented in WHC-EP-0063 are considered to be an integral part of the administrative controls in place at TRUSAF. The difference between the 200 gram waste acceptance 7 imit from WHC-EP-0063 and the 400 gram plutonium limit evaluated in this ISB provides an acceptable margin of safety for TRUSAF operations. The previous safety analysis document, TRUSAF Hazards Identification and Evaluation (WHC 1987), is superseded in its entirety by this ISB.

Items identified in this SER for incorporation into future safety analyses include preparation of appropriate levels of detail for all of the topics specified in DOE Order 5480.23 and inclusion of future waste projection data for comparison to the limits analyzed. This ISB is acknowledged as a basis for the waste acceptance criteria for wastes to be stored at TRUSAF contained in WHC-EP-0063.

As supplemented by this SER, the attached ISB and IOSR present an adequate and acceptable base for authorization of the analyzed operations at TRUSAF. 
WHC-SD-WM-ISB-004 REV 1

This page intentionally left blank. 


\subsection{INTRODUCTION, OVERVIEW AND SUMMARY}

This Safety Evaluation Report (SER) was prepared to meet the requirements in DOE Order 5480.23 (DOE 1992b), and follows the guidance provided in RLP 5480.23 for format and content of an SER, which is consistent with the content of recent SERs that DOE-HQ has found to be acceptable for other DOE facilities and DOE Standard DOE-STD-1104-96, Review and Approval of Nonreactor Nuclear Facility Safety Analysis Reports (DOE 1996). The presentation in this SER follows the topics in the order in which they are presented in the Transuranic Waste Storage and Assay Facility Interim Safety Basis (ISB), (WHC-SD-WM-ISB004, Rev. 0-A) (WHC 1996a) and Transuranic Waste Storage and Assay Facility Interim Operational Safety Requirements (IOSR), (WHC-SD-WM-TSR-002, Rev. 0) (WHC 1996b), respectively, to document the bases for approval of the ISB and associated supporting documents. The ISB is not intended to be fully compliant with DOE Order 5480.23 , but is written to demonstrate adequate levels of safety for the Transuranic Waste Storage and Assay Facility (TRUSAF) operations until a fully compliant SAR is prepared. As such, the ISB is a collection of existing safety documentation and newly prepared evaluations to support safe operations at the TRUSAF, and to provide a clear safety basis for judging changes against unreviewed safety question criteria.

Preparation of this SER is the culmination of an extensive TRUSAF ISB review effort by personnel and support contractors from DOE/RL's Waste Programs, Quality, Safety and Health, and Waste Operations Divisions. Resolutions to the comments from this review based on the october 1995 and July 1996 drafts of the ISB are listed in Attachment 1 . The agreed upon resolutions have been incorporated into the final approved versions of the ISB and IOSR. The documented comments al so included administrative changes, such as clarifications, typos, grammatical corrections, etc., as listed in Attachment 1 .

The TRUSAF consist of a substantial concrete walled building (224-T) where TRU waste is examined and stored. About 1500 55-gallon (208 1iter) drums of TRU waste are currently in storage at TRUSAF. No operations are currently taking place or authorized in the sealed cells along the northeast side of the building.

\subsection{OVERVIEN OF ISB AND ITS CONCLUSIONS}

The purpose of this ISB, as described in Chapter 1.0 of the TRUSAF ISB (WHC 1996a), is to provide the authorization basis required by DOE Order 5480.21 (DOE 1991) and the basis for interim operations of the TRUSAF required by DOE Orders 5480.22 (DOE 1992a) and 5480.23 (DOE 1992b) necessary to demonstrate that the TRUSAF can be operated in a manner protective of public and worker health and safety. Upon approval, this ISB and its associated implementing documentation (IOSR), as supplemented by this SER, will be the basis for safe operations and for determining whether unreviewed safety questions exist associated with changes to TRUSAF operations and/or designs. The ISB format and content follow the requirements of WHC-CM-4-46, Safety 
Analysis Manual (WHC 1995d). This ISB was prepared under the WHC Implementation Plan for DOE Orders 5480.21, .22, and .23 (WHC 1992b) and DOE-STD-3011-94 (DOE 1994b) which provides additional guidance on the intended content of Bases for Interim Operations (BIO) documentation. This ISB is generally consistent with the guidance on format and content contained in that standard.

Chapter 2.0 describes the TRUSAF facilities covered by the scope of this ISB, and Chapter 3.0 summarizes the hazards, controls and mitigation systems, with any operational limitations imposed to maintain risks within acceptable levels from the interim safety analysis. Chapter 4.0 describes the configuration controls imposed during the life-cycle stages of TRUSAF facilities, and references are listed in Chapter 5.0 .

\subsection{SER REVIEW PROCESS}

The SER review process consists of specifically identifying and documenting the bases upon which approval of the subject ISB and supporting documents is granted. This identification can extend to specific parameters and operational restrictions, design features, and source material characteristics deemed by the SER preparers to be significant in terms of protecting health and safety, and defining and evaluating unreviewed safety questions associated with future facility changes. The guidance provided in RLP 5480.23 is followed for the general format and content of this SER. This SER is written to document the review and approval of the TRUSAF ISB (WHC 1996a) and associated supporting documents as required by DOE Order 5480.23 , providing the approved combination of information relating to the control of hazards at the TRUSAF (including design, engineering analysis, and administrative controls) upon which DOE bases its conclusion that activities there can be conducted safely. This Order specifies the required content of an acceptable Safety Analysis, basis for Hazard Classification, and use of a graded approach commensurate with the hazards involved. This SER bases the conclusion of acceptability of the ISB on its compliance with the requirements of DOE Order 5480.23 (DOE 1992b), as augmented by guidance in D0E-STD-1027-92 (DOE 1992C), -1104-96 (DOE 1996), -3009-94 (DOE 1994a), and -3011-94 (DOE 1994b), and the WHC Implementation Plan (WHC 1992b).

The approach used to document the review and conclusions for this SER is to briefly summarize the safety basis information provided in the ISB and supporting documents, evaluate the information provided against the requirements, and 1 ist the significant factors important in making the decision of acceptability and approval of the safety basis. The SER then becomes a part of the overall safety basis, containing specific conditions and factors upon which approval of the ISB and operations at the TRUSAF is granted.

DOE Order 5480.23 (Section 8.b.(3)) identifies 21 topics that are to be addressed in a SAR. DOE-STD-3009-94 discusses how each of the 21 topics are to be addressed in the SAR and how to apply the graded approach for 
non-reactor nuclear facilities. DOE-STD-3011-94 provides further amplification on the content of BIOS (equivalent to the WHC designation ISB). Although the ISB is not intended to be fully compliant with DOE Order 5480.23, coverage of each of the 21 topics will be evaluated in this SER, using the guidance from DOE-STD-3009-94 and -3011-94, as a basis for approval.

The logic and justification for selection of the new proposed IOSRs has been evaluated against the information provided in the safety analysis.

\subsection{SER OVERALL EVALUATION OF THE SAFETY BASIS}

Table 1-1 summarizes each of the 21 topics from DOE Order 5480.23, shows where they are addressed in the ISB and its supporting documents, and provides an assessment of the adequacy of the coverage and the overall acceptability of the information provided in the ISB or supporting documentation for approval of operations at the TRUSAF, as described in more detail in the subsequent sections of this SER. 
Table 1-1. Coverage of DOE Order 5480.23 Topics in the ISB.

\begin{tabular}{|c|c|c|c|c|}
\hline $\begin{array}{l}\text { DOE } 5480.23 \\
8 . \text { b. (3) }\end{array}$ & Topic & $\begin{array}{l}\text { ISB or IOSR Section In } \\
\text { Which Addressed }\end{array}$ & Adequacy of Coverage & $\begin{array}{l}\text { Overall } \\
\text { Acceptability }\end{array}$ \\
\hline (a) & Executive Summary & Not Included & N/A & Not necessary \\
\hline (b) & Statutes/0rders & ISB 5.2 & Comprehensive & Acceptable for ISB \\
\hline (c) & Site Characteristics & ISB $1.1,3.1 .4 .4$, App. B & $\begin{array}{l}\text { Marginal detail to } \\
\text { accommodate modeling }\end{array}$ & Acceptable for ISB \\
\hline (d) & Facility Description & ISB $1.2,2.0$ & $\begin{array}{l}\text { Sufficient detail to } \\
\text { accommodate modeling }\end{array}$ & Acceptable for ISB \\
\hline (e) & $\begin{array}{l}\text { Hazard Analysis/ } \\
\text { Facility Classification }\end{array}$ & ISB 3.0 & $\begin{array}{l}\text { Consistent with DOE } \\
\text { STD-1027-92 }\end{array}$ & Acceptable for ISB \\
\hline (f) & $\begin{array}{l}\text { Health and Safety } \\
\text { Criteria }\end{array}$ & ISB 3.0 & Adequate for ISB & Acceptable for ISB \\
\hline (g) & Waste Management & ISB 3.2 .3 & Adequate for ISB & Acceptable for ISB \\
\hline (h) & Criticality Safety & ISB $3.1 .3,3.2 .2 .3$ & $\begin{array}{l}\text { Program description } \\
\text { adequate }\end{array}$ & Acceptable for ISB \\
\hline (i) & Radiation Protection & ISB 3.2 .3 & Adequate for ISB & Acceptable for ISB \\
\hline (j) & $\begin{array}{l}\text { Hazardous Material } \\
\text { Protection }\end{array}$ & ISB $3.1 .4 .5,3.2 .3$ & Adequate for ISB & Acceptable for ISB \\
\hline$(k)$ & Event Analysis & ISB 3.1 & Sufficient detail & Acceptable for ISB \\
\hline (1) & Management/Safety & ISB 3.2 .3$, IOSR 5.2.1 & Adequate for ISB & Acceptable for ISB \\
\hline
\end{tabular}


Table 1-1. Coverage of DOE Order 5480.23 Topics in the ISB.

\begin{tabular}{|c|c|c|c|c|}
\hline $\begin{array}{l}\text { DOE } 5480.23 \\
8 . \mathrm{b} \cdot(3)\end{array}$ & Topic & $\begin{array}{l}\text { ISB or IOSR Section In } \\
\text { Which Addressed }\end{array}$ & Adequacy of Coverage & $\begin{array}{l}\text { Overall } \\
\text { Acceptability }\end{array}$ \\
\hline (m) & Procedures and Training & ISB 3.2 .3 & Adequate for ISB & Acceptable for ISB \\
\hline (n) & Human Factors & Not Addressed & $\begin{array}{l}\text { Not specifically } \\
\text { required for ISB }\end{array}$ & $N / A$ \\
\hline (0) & $\begin{array}{l}\text { Surveillance and } \\
\text { Maintenance }\end{array}$ & Not Included & Adequate for ISB & N/A \\
\hline (p) & $\begin{array}{l}\text { Technical Safety } \\
\text { Requirements }\end{array}$ & ISB 1.5, IOSR & Adequate for ISB & Acceptable for ISB \\
\hline (q) & Operational Safety & ISB 3.2 .3 & Adequate for ISB & Acceptable for ISB \\
\hline$(r)$ & Quality Assurance & ISB $3.2 .3,4.3$ & Adequate for ISB & Acceptable for ISB \\
\hline (s) & Emergency Preparedness & ISB 3.2 .3 & Adequate for ISB & Acceptable for ISB \\
\hline$(t)$ & $\begin{array}{l}\text { Decontamination and } \\
\text { Decommissioning }\end{array}$ & Not Included & Adequate for ISB & N/A \\
\hline (u) & $\begin{array}{l}\text { Design Codes and } \\
\text { Standards }\end{array}$ & ISB 1.3 & Adequate for ISB & Acceptable for ISB \\
\hline
\end{tabular}




\subsection{SER CONCLUSIONS}

The ISB and its supporting documents present a consistent and adequate set of analyses to demonstrate the safety of current and planned operations at the TRUSAF. With this SER, the ISB and IOSR present an adequate and acceptable base for specific authorization of operations as described at the TRUSAF. The concentration and inventory limits required to ensure continued safe operations appear to be soundly based and accurately determined. Upon approval, this ISB shall be identified as the authorization basis implemented for TRUSAF in the Hanford Site Solid Waste Acceptance Criteria (WHC 1993b), and any necessary changes to WHC 1993b made and forwarded to DOE/RL for approval.

Approval of the ISB and its supporting document (IOSR) is specifically based on WHC adequately performing each of the actions and controls described in these documents and this SER. Any changes to programs, plans, procedures, controls, configurations, or operations from the descriptions in these documents must be evaluated against unreviewed safety question criteria, and DOE approval sought prior to implementing any changes that could affect safety at the TRUSAF, in accordance with DOE Order 5480.21 (DOE 1991).

There are several topics required by DOE Order 5480.23 to be addressed in a SAR that have been given minimal attention in this ISB. Specifically, for instance, Items $8 . b(3)(c),(f),(g),(i),(j),(1)-(q)$, and $(s)-(u)$ (see Table 1-1) will need to be addressed in more detail in the compliant SAR when it is prepared. The level of coverage provided in this ISB is acceptable for authorization of interim TRUSAF activities and operations, however, based on strong site-wide institutional programs in most of the above cited areas that ensure current operations are conducted in a safe manner. 


\subsection{INTERIM SAFETY BASIS REVIEW}

The Transuranic Waste Storage and Assay Facility (TRUSAF) Interim Safety Basis (WHC 1996a) was prepared in accordance with the WHC Implementation Plan for DOE Orders 5480.21, .22, and .23 transmitted to DOE/RL on October 28, 1992, and updated on August 20, 1993 (WHC 1992b). In addition, the guidance in WHC-CM-4-46, Safety Analysis Manual (WHC 1995d), as implemented in the Solid Waste Burial Grounds ISB (WHC-SD-WM-ISB-002), was followed. The stated purpose of the ISB is to provide the "authorization basis" as required by DOE order 5480.21 , and the "basis for interim operation or restrictions on interim operations and administrative controls" required by DOE Orders 5480.22 and .23 , for the active TRUSAF operations in the 200 West Area of the Hanford Site. The SER review of this document is described in the following sections, by ISB chapter.

\subsection{CHAPTER 1 - INTRODUCTION AND SUMMARY REVIEW}

The first chapter of the ISB presents the purpose of the interim safety evaluation and an overview and summary of the safety analysis process and TRUSAF facilities evaluated. The information provided is summarized and evaluated in the following subsections.

\subsubsection{Implementation Plan, Background, Summary and Conclusions}

Section 1.0 of the ISB describes the current and existing TRUSAF authorization basis documentation. The current authorization basis documents include: TRUSAF Hazards Identification and Evaluation (WHC 1987) and Final Safety Analysis for Contact-Handled Transuranic Waste Drum In Situ Inspection and Vented Drum Retrieval (WHC-SD-WM-SAR-058) (WHC 1993a). The Interim Operational Safety Requirements (IOSR) are mentioned. Criticality Safety requirements are documented in Criticality Prevention Specification, Transuranic Waste Storage in 224-T, (CPS-SW-149-00001) (WHC 1989). Planned upgrades to the authorization basis documentation is also mentioned.

The TRUSAF and its background are briefly described in Sections 1.1 and 1.2 , Section 1.3 provides a summary of the configuration management program at TRUSAF, a summary of the safety analysis is given in Section 1.4, and conclusions are summarized in Section 1.5. The TRUSAF is categorized by DOESTD-1027-92 methods as a Hazard Category 2 nonreactor nuclear facility, based on the transuranic nuclide inventory in the stored waste. The safety analys is methodology and results of quantifying potential hazards to onsite workers and the offsite public is also briefly discussed. Conditions that could contribute to hazards include: natural phenomena, normal and upset operations at nearby facilities, radiological and chemical hazards from normal and upset operations at the TRUSAF, impacts of credible accidents, and an assessment of nuclear criticality safety.

Based on the evaluations performed in the ISB and controls as defined in the IOSR, Section 1.5 of the ISB concludes that normal operations will not have significant adverse impacts on the environment, public or workers, and 
that risks from accidents and other abnormal operating conditions are within the risk acceptance guidelines from WHC-CM-4-46 (WHC 1995d). Requirements from applicable DOE Orders are met and the TRUSAF can be operated safely with no undue risks to onsite personnel, the offsite public, or the environment.

\subsubsection{Evaluation Findings}

The information provided in Chapter 1.0 of the ISB is adequate to provide background and understanding of the purpose and scope of the ISB, definition of the facilities being evaluated, summary of the safety analyses performed in support of the ISB and IOSRs, and conclusions of safety of operations at the TRUSAF. The ISB replaces the existing safety documentation for TRUSAF operations, and establishes new IOSRs. The existing SAR for drum retrieval activities (WHC 1994a) is not superseded. On this basis, the old OSRs in WHC $1994 a$ will remain applicable to the specific vented drum retrieval activities analyzed.

DOE-STD-3011-94 (DOE 1994b) suggests that BIOs (ISBs) have an executive summary and a section on Relevant Operational History, which are not present in this ISB.

\subsubsection{Safety Evaluation Conclusions}

The information presented in the first chapter of the ISB adequately summarizes the facility background, operation, and programmatic approach to controlling safety hazards to the workers, the public, and the environment, including the IOSRs established to ensure safety. The references provided are controlled documents or regulations, ensuring that the safety base as described will not be changed in an uncontrolled manner. The ISB specifically refers to the established USQ process for ensuring changes are not allowed that would violate the safety basis. The lack of an executive summary and relevant operational history does not prevent the ISB from satisfying its required role in assuring the safety of existing and planned interim operations at the TRUSAF. The missing sections, Executive Summary and Relevant Operational History, shall also be provided in the required annual upgrade or fully compliant SAR to be prepared.

\subsection{Chapter 2 - Facility Description}

The physical facilities, processes, controls and procedures at the TRUSAF are described briefly in the second chapter of the ISB to identify the design and safety features and administrative controls in place to ensure protection of the environment and the health and safety of the public and workers from associated storage operations and activities. The information provided is summarized and evaluated in the following subsections. 
WHC-SD-WM-ISB-004 REV 1

\subsubsection{Description of Transuranic Waste Storage and Assay Facility and Safety Features}

The TRUSAF is Tocated in the 224-T building in the 200 West Area on the central plateau of the Hanford Site. Transuranic waste is retrievably stored in the TRUSAF pending ultimate disposal at a repository. The details of the 224-T building and installed safety systems and features (fire protection, air sampling and safety communications systems) as well as a process description are presented in this chapter of the ISB.

A brief description of the types and quantities of waste handled at TRUSAF is also presented in Chapter 2.0 of the ISB. Compliance with the requirements implemented in the Hanford Site Solid Waste Acceptance Criteria (WHC 1993b) is identified as a key element to ensure safe TRUSAF operations.

\subsubsection{Evaluation Findings}

The facility descriptions presented in this ISB provide an adequate basis for evaluating the safety of the TRUSAF. Key design parameters and facility operations are described in sufficient detail to support the modeling of performance and risk assessments, and evaluations of effects from normal operations and accident conditions. The descriptions present a picture of a reasonably comprehensive and detailed waste acceptance process, as well as operational controls and features designed to ensure protection of the environment and public and worker health and safety.

One area of information that could be enhanced is a thorough discussion of actual and projected waste inventories and storage duration. Future planned mission changes should also be addressed. Knowledge about future wastes to be handled at the TRUSAF is required to assess the safety and potential consequences of accidents that may occur there. Compliance with the Hanford Site Solid Waste Acceptance Criteria (WHC 1993b) is assumed, but little information on future waste projections is given. A comparison table showing the isotopic waste acceptance criteria limits used as the basis for the safety analyses versus the concentration levels in projected future wastes would provide useful insight into the conservatisms of the approach taken in the safety analyses, and should be included in the planned upgrade to the SAR or ISB.

\subsubsection{Safety Evaluation Conclusions}

The calculations performed for the ISB can be supported by the information on the TRUSAF presented. There are few specific design or operational features other than adherence to the waste acceptance criteria that are taken credit for that actually effect the outcomes of the consequence calculations. The omission of a discussion on mission changes does not directly impact the hazard analyses performed, but could be useful in providing perspective on the necessary IOSRs. While there are few parameters taken from actual design features used directly in the ISB calculations, there are certain general environmental and design provisions upon which the 
underlying analyses and safety conclusions are based, which, if changed, could represent unreviewed safety questions. These include the general storage methodology, and specifically the prohibition on stacking more than two drums high.

The configuration control program in place at the TRUSAF will administratively control changes to these design features through Unreviewed Safety Question screening.

\subsection{Chapter 3 - Interim Safety Basis Evaluation}

The third chapter of the ISB summarizes the identification, evaluation, controls, mitigation systems, and operational restrictions necessary to limit hazards presented by TRUSAF operations to acceptable levels. The information provided is summarized and evaluated in the following subsections.

\subsubsection{Hazards}

The TRUSAF is designated as a Hazard Category 2 nonreactor nuclear facility in accordance with the criteria in DOE Order 5480.23 (DOE 1992b) and DOE STD-1027-92 (DOE 1992C), which indicates that there may be a potential for significant on-site consequences from unmitigated releases, but no significant offsite consequences. The categorization is based on unmitigated consequences from accidents in the TRU waste storage facility without taking credit for any engineered safety features or mitigative actions in place. The safety analyses presented demonstrate that the combination of accident probabilities and consequences meets the same risk guidelines used in the Solid Waste Burial Grounds ISB (WHC-SD-WM-ISB-002). The hazards evaluated include impacts of natural phenomena and radiological hazards from accident conditions at the TRUSAF, and nuclear criticality safety. The accidents analyzed were derived from a comprehensive preliminary hazards analysis which is presented in this chapter.

Radiological hazards to workers and the public are described for accident conditions. Nuclear criticality safety evaluations to derive associated limits are stated to have been performed for TRUSAF. The limits are specified in Tables 3-4, 3-5 and 3-6. By compliance with the limits and storage configurations specified, criticality at TRUSAF has been declared to be incredible.

Section 3.2.1 of the ISB indicates that there are no Safety Class 1 or 2 Structures, Systems or Components (SSCs) associated with the TRUSAF, except the Safety $\mathrm{Class} 2$ items that are identified specifically for the TRU vented drum retrieval activity. Section 3.2.2 addressed operational restrictions, including administrative controls, imposed to maintain the safety of operations at TRUSAF. Institutional safety programs in effect at TRUSAF are described in Section 3.2.3. 


\subsubsection{Evaluation Findings}

The hazard categorization reported in this chapter of the ISB appears to have been performed in a manner consistent with the guidelines in DOE-STD1027-92 (DOE 1992C). Identification of hazards has been done in a comprehensive manner.

The criticality limits and program as described in this chapter of the ISB appear to be adequate to prevent accidental criticalities.

Distances to nearby facilities are not 1 isted, nor are impacts to TRUSAF from accidents at nearby facilities addressed in this ISB. It is implied that $T$ Plant and TRUSAF have a coordinated emergency response program. No worker nor environmental risks from normal operations have been addressed. These deficiencies must be addressed in the 5480.23 compliant SAR or planned upgrade to this ISB.

\subsubsection{Safety Evaluation Conclusions}

Hazards have been appropriately identified and evaluated to ensure continued safe operations at the TRUSAF. The conclusions of safety depend on compliance with the requirements implemented in the administrative controls in the IOSR, including those contained in the Hanford Site Solid Waste Acceptance Criteria (WHC 1993b) and criticality control program described in this chapter of the ISB.

The deficiencies in addressing risks from normal operations and effects from nearby facilities must be remedied in future SAR efforts.

\subsection{Chapter 4 - Configuration Controls System Review}

Chapter 4.0 of the ISB presents details concerning configuration controls during the design and construction, operations, and post-emplacement phases in the life cycle of the TRUSAF facilities. Some of these controls describe procedures and physical configurations important to maintaining the safety of the TRUSAF. The information provided is summarized and evaluated in the following subsections.

\subsubsection{Controls}

Configuration controls that are applied to the TRUSAF are described in this chapter. During design and construction, a formal Configuration Management program as required by 10 CFR 830.120 is provided through controlled manuals. 


\subsubsection{Evaluation Findings}

The descriptions of controls and programs to ensure continued safe operations at the TRUSAF are adequate. Many of the described programs are based on site-wide institutional safety programs implemented on a broader basis than just the TRUSAF. These programs are carefully reviewed and audited on this broader basis, and are credited with being effective in this ISB.

\subsubsection{Safety Evaluation Conclusions}

Credit is taken for the specific content of the IOSRs in ensuring that such items as waste inventories are controlled to remain bounded by the safety evaluations performed. The conclusions of safety in the ISB are contingent on the specific establishment and adequate implementation of the controls described in this chapter and in the IOSRs. Annual reviews of the IOSR are a part of the required annual updates of the SAR (or ISB) required by DOE 5480.23.

\subsection{Chapter 5 - References Review}

The documents cited in the ISB are listed in Chapter 5.0. These references include Federal and State laws, WHC manuals, evaluations and reports, and DOE Orders. The information provided is summarized and evaluated in the following subsections.

\subsubsection{References}

Applicable federal regulations and laws, controlled manuals, and other pertinent safety documentation are listed in this chapter. These cited references provide much of the basis information upon which the safety analyses and risk assessments are performed, as well as the governing rules, regulations and criteria for ensuring operations at the TRUSAF are safely performed.

\subsubsection{Evaluation Findings}

The references provided appear to be comprehensive and sufficient to identify pertinent information necessary to ensure that operations at the TRUSAF will continue to be conducted in a safe and environmentally acceptable manner consistent with appropriate regulatory requirements.

\subsubsection{Safety Evaluation Conclusions}

The references provided are adequate for providing necessary information on the safety bases and regulatory requirements in place at the TRUSAF. 


\subsection{INTERIM OPERATIONAL SAFETY REQUIREMENTS REVIEW}

The Transuranic Waste Storage and Assay Facility Interim 0perational Safety Requirements (IOSR) (WHC-SD-WM-TSR-002) (WHC 1996b) were written to define acceptable conditions and administrative controls required to assure safe operation of the TRUSAF. The format and content are based on requirements from DOE order 5480.22, DOE-STD-3009-94, WHC poljcy, and the safety analyses presented in the ISB. The SER review of the IOSR is described in the following sections, by IOSR section.

\subsection{Section 1 - Use and Application}

This section of the IOSR contains information about use and interpretation of the IOSRs, including applicable definitions. The information provided is summarized and evaluated in the following subsections.

\subsubsection{Contents of Section}

Definitions and usages of terms in the IOSR are provided in this section. Several terms are defined for use in narrowly defined meanings as an aide in interpretation of the IOSRs.

\subsubsection{Evaluation Findings}

The definitions and usages provided are clear, internally self-consistent and adequate for their intended purposes.

\subsubsection{Safety Evaluation Conclusions}

The content and intended usage of the information presented in this section of the IOSR is adequate. The definitions provided appear to be consistent and logical.

\subsection{Section 2 - Safety Limits}

This section of the IOSR contains information about Safety Limits, defined to be parameters which, if violated, would result in uncontrolled releases with unacceptable consequences, and associated Limiting control Settings. The information provided is summarized and evaluated in the following subsections.

\subsubsection{Contents of Section}

Based on the accident analyses presented, there are no postulated accidents which result in unmitigated offsite consequences exceeding 0.5 rem to a member of the public. Therefore, there are no Safety Limits nor Limiting Control Settings applicable to the TRUSAF. 


\subsubsection{Evaluation Findings}

The information presented is acceptable, but could go a step further to state that no reasonable parameter changes would result in unacceptable offsite consequences because of the administrative controls in place at the TRUSAF.

\subsubsection{Safety Evaluation Conclusions}

The reason that there are no unacceptable offsite consequences from waste handling operations is because the waste and TRUSAF operations are assumed to comply with the administrative controls in place. For instance, if waste were received with fissile material concentrations exceeding those assumed from Chapter 5 of the Hanford Site Solid Waste Acceptance Criteria (WHC 1993b), there could be unacceptable consequences. Stating the fact that there are no reasonable changes which could cause unacceptable offsite consequences explicitly in this section of the IOSR will help explain why there are no "operational restrictions" in the sense of safety limits, and why the administrative controls section is so important to the assurance of safety at the TRUSAF.

\subsection{Section 3 - Limiting Conditions for Operation}

This section of the IOSR is intended to contain information about operational limitations including Limiting Conditions for Operations and associated Surveillance Requirements. The information provided is summarized and evaluated in the following subsections.

\subsubsection{Contents of Section}

Based on the interpretation of the safety analyses presented, no Limiting Conditions for Operations nor Surveillance Requirements were identified for the TRUSAF.

\subsubsection{Evaluation Findings}

The information presented is acceptable. However, as stated in Section 3.2.2, it should be expanded to indicate that reliance is placed on administrative controls, with their provisions for quality assurance and maintenance, in lieu of defining any limiting conditions for operations and required surveillances.

\subsubsection{Safety Evaluation Conclusions}

Many of the parameters used in the safety analyses could be construed as "limiting" operations. Exceeding any one of them in a plausible manner will, however, not pose any immediate threats to health and safety. Therefore, WHC 
reliance on administrative controls to ensure that the factors important to safety are not violated or are corrected is judged to be acceptable for the types of operations and levels of constituents of concern at the TRUSAF.

\subsection{Section 4 - Surveillance Requirements}

The Surveillance Requirements contained in this section are generally presented in parallel with Section 3 to show the correspondence between LCOs and Surveillance Requirements. The information provided is summarized and evaluated in the following subsections.

\subsubsection{Contents of Section}

As indicated in Subsection 3.3.1, no Surveillance Requirements were identified for the TRUSAF.

\subsubsection{Evaluation Findings}

Same as described in Section 3.3.2.

\subsubsection{Safety Evaluation Conclusions}

Same as described in Section 3.3.3.

\subsection{Section 5 - Administrative Controls}

This section of the IOSR contains information about the administrative controls imposed at the TRUSAF to ensure safe operations. The information provided is summarized and evaluated in the following subsections.

\subsubsection{Contents of Section}

This section describes the actions to be taken in the event of a violation of an IOSR, a summary of the organization established for the safe and effective handling of operations at the TRUSAF, including minimum shift complements, nuclear criticality safety, and source strength control. The implementing program requirements and key elements are described briefly.

\subsubsection{Evaluation Findings}

The descriptions of the administrative control implementing programs provide specific details as required by DOE-STD-3011-94, Appendix A.7.g, which states, "Discuss and reference the controls in place that maintain the safety envelope of the facility, covering such topics as OSRs, restrictions on operations, and administrative controls." 


\subsubsection{Safety Evaluation Conclusions}

Because this ISB and its supporting IOSR document represent the authorization and safety basis upon which DOE makes its determination of adequate levels of safety, and WHC relies on the use of the administrative controls to maintain safe conditions at the TRUSAF instead of more specific operational limitations in the IOSR, the specific details on the

administrative controls programs provided in the IOSR are justified. Specific reference to the implementing manuals, program documents (such as criticality Safety Evaluations or Analyses), and procedures is the minimum acceptable level of description. The need for this level of definition is especially true for the nuclear criticality safety and source strength control programs upon which the conclusions of adequate levels of safety strongly depend. As written, the current IOSRs appear to meet the regulatory guidel ines and provide sufficient assurance that operations at the TRUSAF will remain within the analyzed safety envelope.

\subsection{Appendix A - Design Features}

This section of the IOSR is designed to contain pertinent design features that must be maintained to keep the conclusions of the safety analyses valid. The information provided is summarized and evaluated in the following subsections.

\subsubsection{Contents of Section}

The IOSR concludes, based on the evaluations reported in the ISB, that there are no design features at the TRUSAF that if altered or modified would have a significant effect on safety.

\subsubsection{Evaluation Findings}

The information provided indicates that all design features important to safety at the TRUSAF are controlled by the general safety and administrative controls programs described in Section 3.0 of the ISB, and therefore do not need to be explicitly listed in Appendix $A$.

\subsubsection{Safety Evaluation Conclusions}

Based on the assumption that all design features important to safety are controlled administratively, it is concluded that no further features need to be listed in this section of the IOSR.

\subsection{Appendix B - Bases}

This section of the IOSR is designed to contain basis information pertinent to the safety limits and operational restrictions imposed. The information provided is summarized and evaluated in the following subsections. 


\subsubsection{Contents of Section}

The IOSR concludes, based on the safety analyses reported in the ISB, that there are no required bases statements, because there are no safety limits nor operational restrictions imposed.

\subsubsection{Evaluation Findings}

The information presented is adequate, based on the assumption that administrative controls at the TRUSAF are sufficient to ensure that safety is maintained. Therefore, no specific bases need be presented for operational restrictions. 


\subsubsection{Safety Evaluation Conclusions}

No specific operational restrictions nor limitations are defined for the TRUSAF beyond those contained in the administrative controls described in Section 5.0 of the IOSR. The ISB and its supporting document (IOSR), as supplemented by this SER, are the bases for determining whether changes represent unreviewed safety questions. 


\subsection{REFERENCES}

DOE 1991, DOE Order 5480.21, Unreviewed Safety Questions, U.S. Department of Energy, Washington, D.C., December 24, 1991.

DOE 1992a, DOE Order 5480.22, Technical Safety Requirements, U.S. Department of Energy, Washington, D.C., September 15, 1992.

DOE 1992b, DOE Order 5480.23, Nuclear Safety Analysis Reports, U.S. Department of Energy, Washington, D.C., Apri1 30, 1992.

DOE 1992C, DOE-STD-1027-92, Hazard Categorization and Accident Analysis Techniques for Compliance with DOE Order 5480.23, Nuclear Safety Analysis Reports, U.S. Department of Energy, Washington, D.C., December, 1992.

DOE 1994a, DOE-STD-3009-94, Preparation Guide for U.S. Department of Energy Nonreactor Nuclear Facility Safety Analysis Reports, U.S. Department of Energy, Washington, D.C., July, 1994.

DOE 1994b, DOE-STD-3011-94, Guidance for Preparation of DOE 5480.22 (TSR) and DOE 5480.23 (SAR) Implementation Plans, U.S. Department of Energy, Washington, D.C., November, 1994.

DOE 1996a, RLP 5480.23, Review and Approval of Nuclear Safety Documents, Richland Operations Office, U.S. Department of Energy, Richland, Washington, March 20, 1996.

DOE 1996b, DOE Standard DOE-STD-1104-96, Review and Approval of Nonreactor Nuclear Facility Safety Analysis Reports, U.S. Department of Energy, Washington, D.C., February, 1996.

WHC 1987, TRUSAF Hazards Identification and Evaluation, WHC-SD-WM-SAR-025, Rev. 0, Westinghouse Hanford Company, Richland, Washington.

WHC 1989, Criticality Prevention Specification, Transuranic Waste Storage in 224-T, CPS-SW-149-00001, Rev. 0, Westinghouse Hanford Company, Richland, Washington.

WHC 1992b, Implementation Plan for DOE Orders $5480.21, .22$, and .23, 9257875, Rev. 1, Westinghouse Hanford Company, Richland, Washington, August 20, 1993 .

WHC 1993a, Final Safety Analysis for Contact-Handled Transuranic Waste Drum In Situ Inspection and Vented Drum Retrieval, WHC-SD-WM-SAR-058, Rev. 0 , Westinghouse Hanford Company, Richland, Washington.

WHC 1993b, Hanford Site Solid Waste Acceptance Criteria, WHC-EP-0063-4, Rev. 4, Westinghouse Hanford Company, Richland, Washington.

WHC 1995d, WHC-CM-4-46, Safety Ana7ysis Manual, Westinghouse Hanford Company, Richland, Washington. 
WHC 1996a, Transuranic Waste Storage and Assay Facility (TRUSAF) Interim Safety Basis (ISB), WHC-SD-WM-ISB-004, Rev. 0-A, Westinghouse Hanford Company, Richland, Washington, September, 1996.

WHC 1996b, Interim Operational Safety Requirements (IOSR), WHC-SD-WM-TSR-002, Rev. 0, Westinghouse Hanford Company, Richland, Washington, September, 1996. 
WHC-SD-WM-ISB-004 REV I

ATTACHMENT 1

REVIEW COMMENT RECORDS

E-27 
WHC-SD-WM-ISB-004 REV 1

This page intentionally left blank. 
PRELIMINARY REVIEW COMMENTS ON TRUSAF ISB

(Forwarded by P. J. Macbeth on 11/17/95)

1. Page 1-1, Paragraph 1, Line 7 - Change "which have been" to "which will have been". Comment accepted.

2. Page 1-2, Paragraph 1 of Section 1.4, Line 1 - Add a specific reference to the location of the preliminary hazards analysis. Comment accepted. Section 3.1.2 will be added to the text.

3. Page 1-2, Paragraph 2 of Section 1.4, Line 6 - The WHC risk acceptance guidelines were "accepted" in the SWBG ISB, not "established". Comment accepted.

4. Page 1-2, Paragraph 3 of Section 1.4 - What is the status of the fire hazards analysis? When will it be available? Comment accepted. Fire hazards analysis draft has been written and will be available shortly. Results conclude that drum fires do not propagate.

5. Page 1-2, Paragraph 1 of Section 1.5 - The risk acceptance guidelines from WHC-CM-4-46 were "accepted" for use in the SWBG ISB, not

"established". Where are the "administrative control interim operational safety requirements" referred to in this paragraph? The current pattern is to have a separate IOSR document to ensure there is no confusion about what are the approved controls. Comment accepted. The IOSRs have been "drafted" similar to the IOSRs written for the LLBG, separate from the ISB and should be approved during the ISB approval process.

6. Page 1-3, Table 1-1 - See the applicable comments in Section 3 on specific consequence numbers that appear in this table. Comment accepted.

7. Page 2-1, Paragraph 4, Line 2 - The "third" referred to in this sentence looks more like "half" in the figure (Figure 2-4). Comment accepted. Text will be revised to "half".

8. Page 2-5, Figure 2-4 - The "sealed radiation measurement laboratory" identified in this figure is not discussed in the text, but should be. Comment accepted. Figure 2-4 will be revised to delete the callout and legend referring to a sealed radiation measurement laboratory. It does not exist.

9. Page 2-7, Paragraph 1 - Show these features in Figure 2-4. Comment accepted. Fiqure 2-4 will be revised to reflect the current configuration, which includes a restroom and a control/operations office.

10. Page 2-7, Paragraph 5 - Show the double metal door in Figure 2-4. The "two floors high" ceiling in the extreme southeast portion of the receiving area is not shown in Figure 2-4, but should be. Comment accepted. Figure 2-4 will be revised to show the double metal door and two floors high ceiling. 
11. Page 2-7, Paragraph 7, Line 15 - Add "aisles" after "(30 in.)". Comment accepted.

12. Page 2-10, Paragraph 1 of Section 2.4 - Where is K1-82 described? Is "magnehel ic" a brand name or a type of instrument? Comment accepted. K1-8-2 will be added to the description of $\mathrm{K} 1-8-1$. "Magnehelic" will be revised to "differential pressure indicator".

13. Page 2-11, Paragraph 4, Line 6 - Change "fissile" to "contaminated". Comment accepted.

14. Page 2-11, Paragraph 5, Last bullet - What about the other fan? Does it stay on? A little more detail here would be helpful. Comment accepted. The last bullet will be changed to: "Cuts power to the K1-8-2 exhauster fan and supply fan $K 1-7-1$, while fan $\mathrm{K} 1-8-1$ stays on".

15. Page 2-12, Paragraph 1, Line 2 - Is "accords to" normally accepted usage? Reconcile the last sentence in this paragraph with the statement on Page 2-8, Paragraph 2, that states the locations are recorded in the referenced document. Comment accepted. Text will be revised to "in accordance with". Page 2-8, paragraph 2, 1st sentence will be revised to: "Constant air sampling of operating and storage areas on each of the three floors is provided by continuous air monitors (CAMs), however workplace sampling is not required. The third sentence will be revised to: "The requirements for sampling/monitoring is documented in Technical Assessment of Workplace Sampling at TRUSAF, WHC-SD-SOA-TA-20015, Rev. 0 (WHC 1995b)".

16. Page 2-12, Paragraph 5, Line 3 - Is there just one, "a", CAM? Comment accepted. Text will be revised to "CAMs."

17. Page 2-13, Paragraph 3, Line 2 - Add "liquid" between "other" and "effluent". Comment accepted.

18. Page 2-14, Paragraph 2, Line 1 - Change "meter" to "scale". Comment accepted.

19. Page 2-14, Paragraph 3 - Add the general criteria for x-raying drums to this description of the process. Comment accepted. Revise lst sentence of paragraph 3 to: "Containers slated for verification are then moved by a hand-operated forklift to the RTR operating room".

20. Page 2-15, Figure 2-6 - Is this the ground level? Add a legend to that effect. Also, describe what the lines represent. Are the boundaries between the staging and storage areas shown in the figure walls? Comment accepted. The figure is ground level. The process fiow path will be changed to dash lines and a legend added.

21. Page 2-17, Paragraph 2, Line 1 - Add the explanation found in Section 3.1.3.5.2 to this section also as to why drums are only stacked two high. Comment accepted.

22. Page 2-18, Paragraph 1 , Line 2 - Here is a good 5 I conversion factor for you $-35.314 \mathrm{ft}^{3}=1 \mathrm{~m}^{3}$. So, $1 \mathrm{~W} / \mathrm{ft}^{3}=35.3 \mathrm{~W} / \mathrm{m}^{3}$. Comment accepted. 
23. Page 3-3, Paragraph 2, Line 3 - There must be some words missing around "filters radioactive" in this sentence. Add a definition for PE-C $i$ and MFP to this paragraph. Comment accepted. "filters radioactive material" will be changed to "radjoactive material on the filters " in the text. Where the acronyms PE-Ci and MFP first appear in this paragraph, they will be replaced with the full terms "Plutonium Equivalent Curie (PE-Ci) and Mixed Fission Products (MFP) along with the acronyms in parenthesis. The following definition will be added to follow the terms:

\begin{abstract}
PE-Cj is the concept where all of the radiological activities, in curies, attributable to the individual isotopes present in TRU material are converted to an equivalent activity of ${ }^{239} \mathrm{Pu}$ in curies Mixed Fission Products (MFP) are those isotopes formed in the fission process. Specifically excluded are isotopes included in the definition of TRU material.
\end{abstract}

24. Page 3-3, Paragraph 3 - Explain and justify how the drum deflagration accident is selected as bounding for the hazard categorization. Comment accepted. The following discussion will be added to the paragraph. "Based on the discussion in this section concerning the determination of the final hazard categorization. the drum deflagration accident was selected as the bounding accident for the hazard categorization because its onsite and offsite dose consequences were the largest of all of the accidents tabulated in Table 1-1." Note that the vehicle fire accident has been dropped from the analys is because it is external to the facility.

25. Page 3-3, Paragraph 4 - Provide a basis for this conclusion or interpretation of DOE-STD-1027-92, that the inventory of only a single drum in storage sets the hazard categorization. Comment accepted. The paragraph will be replaced by the following discussion. "Available material in this final hazard categorization is the material contained in the facility that is involved in the postulated accident, considering its form, location, dispersibility and interaction with available energy sources."

26. Page 3-4, Paragraph 2, Line 5 - What is meant by "the first component listed above will be conservatively included ..." What about the other components? Clarify this paragraph. Comment accepted. The second and third sentences in the paragraph will be replaced with the following discussion. "It can be seen from the calculated releases from equations 12 and 13 in Section 3.1.3.3.2, that there is a greater release from the fire than from the explosion. In fact, there is an order of magnitude difference less between the amount released as a result of the explosion $\left(A_{0}\right)$ and the amount released by the fire $\left(A_{1}\right)$. To simplify the hazard category calculations, the material at risk for the explosion will be included in with the material at risk for the burning of ejected combustible waste.

27. Page 3-5, Paragraph 3, Line 4 - Add "for "between "fraction" and "noncombustible". Comment accepted. 
28. Page 3-6, Table 3-1 - Note that this categorization is for only one drum. There were 18 drums involved in the accident in 3.1.3.4. Explain how this analysis supports the hazard category 3 determination. Comment accepted. Please refer to the resolution to comment 24 where it was noted that the vehicle fire accident has been dropped from the analys is because it is external to the TRUSAF building.

29. Page 3-7, Paragraph 6, Line 7 - Which "risk criteria" are being discussed, WHC's? Comment accepted. A reference will added after the term "risk criteria" which will reference WHC onsite and offsite risk acceptance criteria contained in appendices in the solid waste burial ground (SWBG) ISB.

30. Page 3-8, third bullet, Last line - Add "PE-C $i$ " to end of sentence. Comment accepted.

31. Page 3-16, Paragraph 2, Line 4 - Are these "measurements and other controls" included in the IOSRs? Comment accepted. The measurements and other controls referred to here in the text are part of the Criticality Program, which will be included in the IOSRs as Administrative Control 5.3. Nuclear Criticality Safety.

32. Page 3-17, Paragraph 3, Last sentence - The SWBG ISB accepts the use of $100 \mathrm{~m}$ for the distance to an uninvolved on-site worker for the SWBG (outdoor facilities with no distinct boundaries). It does not "define" the on-site receptor as being at least $100 \mathrm{~m}$ away. I would suggest that the appropriate "definition" to use here would be the closest normally occupied facility not in the TRUSAF/T Plant Emergency Planning horizon. Comment accepted. The second and third sentences will be replaced with "The maximum onsite receptor for both TRUSAF and $T$ Plant which is the closest normally occupied facility not in the TRUSAF/T Plant Emergency Planning horizon, is located $0.5 \mathrm{~km}(500 \mathrm{~m})$ SSE at the M0-279 Building.

33. Page 3-18, Table 3-8 - Explain what the correction factors in Column D are, and give their source. Comment accepted. A footnote will be added to Table 3-18 which references the source for the correction factors as Appendix C in WHC-EP-0063, "Hanford Site Solid Waste Acceptance Criteria", and explains that the dividend in the factors in D is the ratio of the dose conversion factor for the isotope to the dose conversion factor for ${ }^{259} \mathrm{Pu}$.

34. Page 3-19, Paragraph 1, Last sentence - Add a specific reference to the coordination activity described, and ensure that this factor for which credit is taken is included in the appropriate IOSRs. Comment accepted. The last sentence will be revised to clarify that TRUSAF and T Plant are parts of the Solid Waste Disposal organization and as such will have appropriately coordinated emergency plans as well as other programs to ensure safe operation of the facilities and worker protection.

35. Page 3-19, Paragraph 4, Line 2 - What is the basis for the 0.01 LPF? Comment accepted. The first sentence of the paragraph containing the 0.01 LPF will be deleted. It can be deleted here because it is explained in following paragraphs. 
36. Page 3-20, Line 12 - What is the basis for the LPF of 0.01 ? Comment accepted. The sentence beginning with "For higher heights..." should be replaced with "For drops from heights greater than $1 \mathrm{~m}$ ( $4 \mathrm{ft}$ ), a LPF of 0.01 is estimated. This value for the LPF is the fraction obtained when the area of the opening resulting from lid distortion is divided by the surface area of the drum."

37. Page 3-23, Paragraph 3, Last sentence - Section 3.1.3.2.5 should be "beefed up" to more clearly show that this sensitivity analys is has been performed. Comment accepted. Note that in response to item 46, Sections 3.1.3.2.5 and 3.1.3.3.5 have been improved with regard to describing conditions that lead to fire propagation between drums. The last sentence of Sections 3.1 .3 .2 and 3.1 .3 .3 will be deleted to avoid confusion.

38. Page 3-25, Section 3.1.3.2.3 - Follow the pattern established in Section 3.1.3.1.3 in showing the parameters used to determine the consequences. I cannot get the answers shown using the parameters described earlier. Where did the numbers come from? Add some more words to explain the difference between mitigated and unmitigated release quantities, and why they are both being calculated. Comment accepted. Calculations will be added in Section $3,1.3 .2 .3$ to support the dose consequences reported in Tables 3-12 and 3-13. Unfiltered results will be reported in Table 3-12 and filtered and unfiltered results currently shown in Table 3-13 remain, where they are compared to guidelines. The reason for calculating both values with be added to Section 3.1.3.2.3.

39. Page 3-26, Section 3.1.3.2.5 - Follow the pattern established in Section 3.1.3.1.3 in showing the parameters used to determine the consequences. I cannot get the answers shown using the parameters described earlier. Where did the numbers come from? Add some more words to explain the difference between mitigated and unmitigated release quantities, and why they are both being calculated. Comment accepted but note that its disposition has been accomplished in item 38. Section 3.1.3.2.3 has the function to determine and report the dose consequences while Section 3.1 .3 .2 .5 . takes those results and makes comparisons to criteria and draws conclusions.

40. Page 3-26, Paragraph 2, Line 1 - Correct the grammar in this line. Comment accepted.

41. Page 3-27, Paragraph 1 - Section 3.1.3.3.5 should be "beefed up" to show this sensitivity analysis. Comment accepted. Note that in response to item 46, Sections 3.1.3.2.5 and 3.1.3.3.5 have been improved with regard to describing conditions that lead to fire propagation between drums. As in the response to Item 37, the last sentence of Sections 3.1.3.2 and 3.1.3.3 will be deleted to avoid confusion.

42. Page 3-27, Paragraphs 3 and 4 - Reconcile the 0.1 ARF claimed in the end of the third paragraph with the 0.001 stated in the first sentence of the fourth paragraph. Or justify the conclusion that material "ejected" during the explosion is not airborne, and application of an additional ARF is reasonable. This is required to justify equation (12) on the following page. Comment accepted. A discussion will be added to the 
third paragraph to clarify that the $10 \%$ of the material ejected from the drum is not an ARF, but that 1 tenth of all of the rags and plastic etc. in the drum are blown out of the drum and 9 tenths stay in the drum to burn in place. The 0.001 ARF is applied to that $10 \%$ ejected.

43. Page 3-28, Paragraph 2, Line 2 - Use of "ARF/RF" is confusing and must be avoided, as must the "6 $\times 10^{-3} / 0.01 "$ form, both of which imply division when multiplication is used. This comment applies to the entire text. Also be careful with "an overall RF of" found in the 4 th line of this paragraph, which is not consistent with precise usage of the definitions. The logic on this page is cloudy to me. Explain why the burning of the ejected material has an ARF of 0.01 , while the burning of the non-ejected material has an ARF of $5 \times 10^{-4}$. Comment accepted. The / symbol will be replaced with the word "and". For cases where a multiplication occurs to yield a Respirable Airborne Release Fraction (RARF) the ARF value and the RF value will be enclosed in parenthesis and separated by a multiplication sign, i.e. $\left(6 \times 10^{-3}\right) \times(0.01)=6 \times 10^{-5}$. The term "overal1 RF" will be replaced by Respirable Airborne Release Fraction (RARF). Further discussion on the differences between the release fractions and how they are applied will be added to this section.

44. Page 3-29, Section 3.1.3.3.3 - Follow the pattern established in Section 3.1.3.1.3 in showing the parameters used to determine the consequences. I cannot get the answers shown using the parameters described earlier. Where did the numbers come from? Add some more words to explain the difference between mitigated and unmitigated release quantities, and why they are both being calculated. Comment accepted. Calculations will be added in Section 3.1.3.3.3 to support the dose consequences reported in Tables 3-14 and 3-15. Unfiltered results will be reported in Table 3-14 and filtered and unfiltered results currently shown in Table 3-15 remain, where they are compared to guidelines. The difference and reason for calculating both values will be added to Section 3.1.3.3.3.

45. Page 3-30, Line 3 - The requirement to vent the drums results in the order of magnitude reduction in frequency; not visa-versa as stated. Comment accepted. In line 3, the words "accounts for" will be replaced by "results from".

46. Page 3-30, Paragraph 2, Line 1 - State more clearly that fires do not propagate in stacks of drums, and be sure that Section 3.1.3.2.1 actually justifies this conclusion. Comment accepted. The first sentence will be replaced with "As documented in Section 3.1.3.2, no fire propagation occurs between drums, except when the drums are directly within the flames of an extended hydrocarbon fuel fire or where drums are on combustible pallets adjacent to a hydrocarbon fuel fire. This same addition will be added to the similar paragraph in Section 3.1.3.2.5.

47. Page 3-33, Section 3.1.3.4.3 - Follow the pattern established in Section 3.1.3.1.3 in showing the parameters used to determine the consequences. I cannot get the answers shown using the parameters described earlier. Where did the numbers come from? Add some more words to explain the 
difference between mitigated and unmitigated release quantities, and why they are both being calculated. Comment accepted but note in the response to comment 24 that the vehicle deflagration accident, which is the subject of Section 3.1.3.4, will be deleted from the analys is so further calculations are not provided.

48. Page 3-35, Equation (24) - Add an explanation that this equation assumes that the entire inventory is made airborne and inhaled, with no dispersion or breathing rate considered. Also explain the use that is going to be made of this equation's results. Comment partially accepted. A statement will be added to the end of the second sentence in the paragraph immediately preceding equation 24 indicating that the inventory is respirable material and that it is given in rems which were calculated from curies without the breathing rate considered. Note however that this is a source term and has been included in the Source Term section 3.1.3.5.2. Following the pattern of previous sections, source terms were determined in Source Term sections and downwind dose consequences were calculated in the following Consequences section. This is the case here where the onsite and offsite dose consequences are calculated in Section 3.1.3.5.3 using the source term in rems from equation 24.

49. Page 3-37, Equations (32) and (33) - Change "E-07" to "E+07". Comment accepted.

50. Page A-3, Paragraph 2, Last sentence - Delete "Using" and "is more conservative" at the end. Comment accepted.

51. Page B-4, Paragraph 1, Line 2 - Clarify that "12\% Pu" means "12\% Pu-240". Th is terminology al so appears in Table B-2, last row. Comment accepted. $12 \% \mathrm{Pu}$ will be replaced by $12 \%{ }^{240} \mathrm{Pu}$.

52. Page B-5, table B-3 - Clarify that these results are for inhalation of the total inventory without dispersion or breathing rate considerations. Comment accepted. In a similar manner to response 48, a statement will be added to the end of the last paragraph on page B-4 indicating that the inventory is respirable material and that it is given in rems which were calculated from curies without the breathing rate considered. Determination of potential dose consequences to an individual would be based on this total inventory multiplied by the breathing rate and the appropriate dispersion factor.

53. Page D-3, Paragraph 2, Last line - Clarify the location of the cited reference to "(Appendix B, p. B-4)". Comment accepted.

54. Page D-3, Paragraph 3, Line 4 - Change "67.6by" to "7.6 by". Comment accepted.

Comments from R. F. Guercia:

55. Page 2-1, Paragraph 2, Line 2 - Specify which DOD generators, and note that the Pilot Retrieval Project is now complete. Comment accepted. The words "from U.S. Department of Defense and" will be removed from this sentence. 
56. Page 2-1, Paragraph 4, Line 9 - Add "air" before "1eakage". Comment accepted.

57. Page 2-7, Paragraph 7, Line 10 - Verify that the $200 \mathrm{~g}$ limit comes from WHC-EP-0063, and not the 01d SAR. Comment accepted. The $200 \mathrm{~g}$ limit for drums is based on the criticality analys is limit for stacking of the TRU drums. This limit is administratively controlled by the waste acceptance criteria of WHC-EP-0063.

58. Page 2-7, Last sentence - Clarify that the administrative controls and IOSRs include the waste acceptance criteria, and that the current version is WHC-EP-0063-4. Clarify that it is not intended that an ISB change be processed to revise the waste acceptance criteria. Comment accepted. The "-4" will be removed from WHC-EP-0063 in the last sentence on page 27. WHC-EP-0063 will be specifically called out in the administrative controls section of the IOSRs as identified in Section 3.2.2.3, page 3-47 of this ISB. The following sentence will replace the 2 nd sentence of the 1st paragraph of section 3.2.3: "These manuals and/or successor guidance documents include, but are not limited to the following:."

59. Page 2-8, First bullet, Line 1 - What "canyon" is meant? Comment accepted. The word "canyon" will be removed from text.

60. Page 2-9, Paragraph 2 - Is there a newer reference, or has there been any change since 1989 in worst drum? Comment accepted. This drum remains the highest quantity drum assayed to date.

61. Page 2-13, Paragraph 3 - What about heat pump effiuents? Comment accepted. The following sentence will be added "The heat pump effluent is piped to the fire riser drain".

62. Page 3-4, Paragraph 3, Line 4 - Same question as before about waste acceptance criteria. Does this specific call out to WHC-EP-0063-4 mean an ISB change would be required if it went to WHC-EP-0063-5? Comment accepted. The "-4" will be removed from WHC-EP-0063. The USO process will be used to determine if proposed changes to WHC-EP-0063 require changes to the ISB. 


\section{COMMENTS ON TRUSAF ISB (WHC-SD-WM-ISB-004)}

DATED JUNE 1996

1. Page 1-2, Paragraph 1, Lines 13 and 14 - Change "design requirements, and facility design" to "design and safety analysis requirements, and that these". Comment accepted and text changed as requested.

2. Page 1-2, Paragraph 3, Line 5 - The risks of operations at the LLBG were accepted in ISB-002 (not the ISA SARR-028). The risk acceptance guidelines were not "accepted" for general use. Revise the wording to say: "The risks from analyzed TRUSAF operations are within the guidelines from WHC-CM-4-46 as accepted in the LLBG ISB-002", or words to that effect. This comment also applies to the second sentence in Paragraph 5 on this page. Comment accepted. The sentence will be revised to "The risks from analyzed TRUSAF operations are within the same risk quidelines accepted in the SWBG ISB (WHC 1995a).

3. Page 1-2, Paragraph 4, Line 4 - Add a reference for the fire hazards analysis. Comment accepted and text changed as requested.

4. Page 2-2, Figure 2-1 - Move the WPPSS plants to inside the WPPSS area. Comment accepted and figure revised as requested.

5. Page 2-3, Figure 2-2 - Show the TRUSAF area in more detail. For instance, where is the operations trailer discussed in the text? Comment accepted and fiqure revised to expand area next to $T$ Plant, so that the Operations Trailer, M0-289 will be identified.

6. Page 2-4, Figure 2-3 - Check the direction on the arrow leaving the elevator vestibule. If the building is maintained negative with respect to outside, how can the flow be outward? Comment accepted and figure revised to delete arrow marked elevator vestibule.

7. Page 2-5, Figure 2-4 - Where are the double metal door and temporary staging area described on Page 2-7? What is the opening in the second floor southeast wall in cell E? Are the areas beyond cell $F$ sealed or open? Where is the ceiling two floors high? Comment accepted. Metal double door added to fiqure. Opening in the second floor southeast wall is covered with a structural metal plating. The areas beyond cell $\mathrm{F}$ are sealed. The ceiling is two floors high above RTR and storage area on the first floor.

8. Page 2-7, Paragraph 2, Line 3 - Provide a description of the operations trailer. Comment accepted and the following sentence added to this paragraph: "The Operations Trailer, M0-289 is located adjacent to 224T".

9. Page 2-7, Paragraph 7, Line 3 - Add "Central Waste Complex (CWC)" to this list per Page 2-15. Comment accepted and text changed as requested.

10. Page 2-7, Paragraph 7, Line 11 - Change "container" to "containers". Comment accepted and text changed as requested. 
11. Page 2-8, Paragraph 2, Line 2 - Add "routine" between "however," and "workplace". Comment accepted and text changed as requested.

12. Page 2-8, Paragraph 5, Line 1 - Change "on $7 y^{\prime \prime}$ to "except". Comment accepted and text changed as requested.

13. Page 2-9, Line 2 - Explain what a margin of safety of 0.14 means. Comment noted. As discussed in the referenced memo, Chenault 1993, the margin of safety for bending and shear is equal to the Allowable divided by the Actual minus 1. The following sentence will be added to the text to clarify: "As used here, marqin of safety represents the fraction of allowable stress in excess of the maximum design stress."

14. Page 2-9, Line 6 - Change "for" to "because of". Comment accepted and text changed as requested.

15. Page 2-9, Line 13 - Change "the ground" to "of horizontal". Comment accepted and text changed as requested.

16. Page 2-9, Paragraph 2 - Clarify the data sheet value versus the assayed value, and describe how these values are reconciled. Change "to date" in the last sentence to "through July 1996". Comment accepted and text revised as requested. Additionally, "3,000" will be revised to " $>5,000$ " and the following sentences will be added: "The assay results may have substantial error (or bias) for large TRU content drums, since the equipment is designed for accurate measurement of low quantities of fissile material, however, the error in measurement increases with higher quantities of fissile material. If the assayed quantity exceeds the waste-acceptance criteria of $\angle 200 \mathrm{~g}$ of TRU, it may be stored at the TRUSAF, provided the drum does not exceed $400 \mathrm{~g}$. To conservatively determine the risk associated with the storage of these drums at the TRUSAF, the analysis provided by this document assumes a maximum TRU drum loading of $400 \mathrm{~g}$." Additionally for clarification, the following sentences will be added to the first paragraph on page 2-16 after the 1st sentence: "When drums assay $>200 \mathrm{~g}$ of TRU, the waste generator is contacted to verify accuracy of records and when verified, the waste generator record is used with assay results noted. Drums that cannot be reconciled with the waste generator will be marked as "Hold", pending resolution requiring further analysis."

17. Page 2-10, Paragraph 3, Line 4 - Change "fan K1-8-1" to "fans K1-8-1 and/or K1-8-2". Comment accepted and text changed as requested.

18. Page 2-11, Paragraph 1 - Explain how this is possible with a negative building pressure. Comment accepted and changed "is exhausted" to "may escape". Even with a neqative pressure some air will exit due to turbulence at a large opening.

19. Page 2-11, Paragraph 3 - The second sentence of this paragraph should be deleted. It is redundant with the last line on Page 2-10. Comment accepted and text changed as requested. 
20. Page 2-11, Paragraph 5, Line 6 - Change "fissile solutions" to "contaminated fluids". Comment accepted and text changed as requested.

21. Page 2-12, Second bullet - Power to which exhaust fan is cut off? What happens to the other fan? Comment accepted and second bullet revised to: "Cuts off power to the air-supply fan and both exhaust fans".

22. Page 2-12, Paragraph 2, Line 3 - Add "routine" between "a" and "workplace". Comment accepted and text changed as requested.

23. Page 2-13, Paragraph 5 - Where is the GWAS pre-shipment review and acceptance process described? Comment accepted and the following bullet added to text: "The waste generator obtains advance approval for storage in TRUSAF through waste acceptance contact."

24. Page 2-14, Figure 2-6 - Label this as the ground or first floor. Comment accepted and fiqure revised as requested.

25. Page 2-15, Paragraph 4, Line 1 - Add a brief description of how and which containers are "slated for verification". Comment accepted and the following sentence will be added after the lst sentence of paragraph 4: "The need for verification is based on the performance history of the waste generator."

26. Page 2-16, Paragraph 4, Line 9 - Correct the drum wall thickness to "1.07 $\mathrm{mm}^{\prime \prime}$. It is very unlikely that any drums are $1 \mathrm{~cm}$ thick. Comment accepted and text changed as requested.

27. Page 3-1, Paragraph 5 - There is a line of text missing at the bottom of this page. Add "threshold quantities are not exceeded. The facility is Hazard Category 2". Comment accepted and text changed as requested.

28. Page 3-2, Paragraph 5, Line 8 - Move the cited reference "(WHC 1989)" to between "document" and "were reviewed". Comment accepted and text changed as requested.

29. Page 3-5, Table 3-1 - Review the probability of gas buildup (first row on this page). It may be Unlikely for a single drum, but for all of them in storage it may be Anticipated. Comment noted and discussed. No change necessary.

30. Pages 3-6 and 3-7, Table 3-1 - Review the Severity of several entries on these two pages. If there are really Severity I type events possible in the Unlikely probability category, TRUSAF would meet the definition for a Hazard Category l facility. How could a drum fire or explosion cause a fatality? Comment noted. Descriptions are provided for each accident as part of the PHA. No change necessary.

31. Page 3-12, Paragraph 1, Line 6 - Delete "Software Design Descriptions, WHC-SD-WM-SWD-009, Rev. 8". Perform a document word search to correct this citation to SWITS in all occurrences. Comment accepted and text changed as requested. 
32. Page 3-12, Paragraph 2 - The T Plant ISB says 222-T is unoccupied. Which is correct? Correct the text to properly describe 222-T. Comment accepted. Building 222-T is unoccupied and the will be deleted from the text here.

33. Page 3-12, Table 3-7 - Correct the reference to footnote "b" (add "b" to the Note below the table). Comment accepted and text changed as requested.

34. Page 3-14, Paragraph 3, Line 1 - Change "release" to "releases" and "ARF/respirable fractions" to "Airborne Release Fractions (ARF) and respirable fractions". Do not use the "ARF/RF" notation. Perform a word search on the entire document and change it to "ARF and RF" both in the words and the numerical examples. Comment accepted and text changed as requested.

35. Page 3-14, Paragraph 3, Line 3 - Change "This" to "These". Comment accepted and text changed as requested.

36. Page 3-14, Paragraph 4, Line 6 - Add "airborne" between "overal1" and "fraction". Comment accepted and text changed as requested.

37. Page 3-14, Paragraph 5, Line 10 - Change "accident" to "Accident". Comment accepted and text changed as requested.

38. Page 3-14, Paragraph 5, Line 12 - Change "then that" to "than". Comment accepted and text changed as requested.

39. Page 3-14, Paragraph 5 Lines 16 and 17 - Change " $1 \mathrm{~m}$ " to " $1.2 \mathrm{~m}$ " for 4 feet as shown in Line 8 of Paragraph 1 . Comment accepted and text changed as requested.

40. Page 3-15, Lines 3 and 4 - See comment number 34 . Comment accepted and text changed as requested.

41. Page 3-15, Equation (2) - Add a brief paragraph after this equation explaining why two source terms (unmitigated and filtered) are presented in the consequences that follow. Comment accepted and the following sentence added preceding equation 2: "The consequences of the unmitigated and filtered releases are provided to establish likely consequences for the preceding accidents presented and for the unmitigated consequence if the filters were breached to determine the safety significance of the ventilation system."

42. Page 3-15, Paragraph 3, Last sentence - The referenced section numbers are not correct. Comment accepted and the last sentence deleted.

43. Page 3-16, Paragraph 3, First sentence - Clarify the wording of "with the consequence values". Comment accepted and "with the consequence values has been deleted". 
44. Page 3-17, Paragraph 1 - Clarify these frequencies. How can the frequency of an accident depend on the location of the receptor? This is not consistent with Table 3-3. Al so, correct footnote " $c$ " under Table 310 to show the corrected values. Comment accepted and the text changed to reflect the frequencies to be the same for onsite and offsite.

45. Page 3-18, Paragraph 5, Line 8 - Delete the comma after "released". Comment accepted and text changed as requested.

46. Page 3-19, Paragraph 1, Line 2, Paragraph 2, Lines 1 and 2, and Paragraph 3 , Line 5 - See comment number 34 . Comment accepted and text changed as requested.

47. Page 3-19, Paragraph 1, Line 4-Clarify what the three categories mentioned are. Note that there are only two described in the following text. Comment accepted. The following text will be added following the sentence that 1ists the three categories. "The ARF's and RF's for the 1st and 3rd categories, i.e. packaged waste and contaminated noncombustible solids, are applicable to this analysis for a drum fire. Packaged waste is appropriate for drummed waste because a plastic liner is present in the drum which after filling is wrapped close and tied off. Further, the material is often contained in individual plastic packets. ARF's and RF's for noncombustible solids cover the contaminated solid articles in the waste such as tools, pipe and scrap metal. The ARF and RF for uncontained waste is not applicable to a drum fire but is used for drum explosions to analyze the release due to burning of material dispersed by any explosion."

48. Page 3-22, Paragraph 1, Line 1 - Change "3.1.4.2" to "3.1.4.2.1". Comment accepted and text changed as requested.

49. Page 3-22, Paragraph 1, Lines 4 and 5 - Change "fire is small and installed fire detection/suppression systems are" to "installed fire detection/suppression systems are". Comment accepted and text changed as requested.

50. Page 3-24, Paragraph 1, Line 2 - Delete "a" before "bounding" and change "value" to "values". Comment accepted and text changed as requested.

51. Page 3-24, Paragraph 1, Line 4 - change "a Respirable Airborne Release Fraction (RARF)" to "an overall airborne fraction" per Page 3-14, Paragraph 4, Line 6 . Do not invent a new acronym for a single use. Comment accepted and text changed as requested.

52. Page 3-27, Paragraph 1, Line 1 - Change "3.1.4.2" to "3.1.4.2.1". Comment accepted and text changed as requested.

53. Page 3-27, Paragraph 1, Lines 4 and 5 - Delete "fire is sufficiently small enough to not activate" and add "are not activated" to the end of the sentence. Comment accepted and text changed as requested.

54. Page 3-27, Paragraph 5, Line 4 - Make the drop distance consistent with Page 3-14 (4 feet instead of 3 feet). Comment noted, discussed and determined to be okay as written. No change necessary. 
55. Page 3-28, Paragraph 3, Line 6 - Add "in the actual configuration" to the end of the last sentence in this paragraph. Comment accepted and text changed as requested.

56. Page 3-28, Paragraph 4 and Equation (23) - This inventory as a dose idea is not clearly presented. Label these results as "dose potential" or something to identify the fact that it is not a true dose projection. Comment accepted and text changed as requested. The following additional sentence added to the Note following equation 23: "This is not a true dose projection".

57. Page 3-28, Paragraph 5 - Add a sentence on the representivity of this approach in determining the bounding inventory. That is, how do the operating conditions compare with current operations, etc.? Comment noted. The description provided is based on historical information on filter inventories.

58. Page 3-29, Paragraph 1, Line 3 - Change "The filters" to "the filters". Comment accepted and text changed as requested.

59. Page 3-30, Equation (30) - What does this equation mean? Why are MFP and TRU activities added together? I suggest it be deleted. Comment accepted, the MFP and TRU activities should not be added together. so equation 30 will be eliminated. Individual dose consequences for MFP and IRU will be calculated and then they will be combined to get the total dose consequence. The following calculations will substituted for equations 33 and 34 on paqe $3-30$. Note that with the elimination of equation 30 , equations 31 and 32 drop back to 30 and 31 , so the following numbers are in sequence.

$$
\begin{aligned}
& \text { Onsite }_{\text {TRU }}=\left(1.64 \times 10^{-5}\right)\left(5.94 \times 10^{-4}\right)\left(3.3 \times 10^{-4}\right)\left(6.0 \times 10^{7}\right) \\
& =1.93 \times 10^{-4} \mathrm{rem} \\
& \begin{aligned}
\text { Offsite }_{\text {TRU }}= & \left(1.64 \times 10^{-5}\right)\left(1.48 \times 10^{-5}\right)\left(3.3 \times 10^{-4}\right)\left(6.0 \times 10^{7}\right) \\
& =4.81 \times 10^{-6} \mathrm{rem}
\end{aligned} \\
& \begin{aligned}
\text { Onsite }_{\mathrm{MFP}}=\left(2.69 \times 10^{-6}\right) & \left(5.94 \times 10^{-4}\right)\left(3.3 \times 10^{-4}\right)\left(2.1 \times 10^{5}\right) \\
= & 1.11 \times 10^{-7} \mathrm{rem}
\end{aligned} \\
& \begin{aligned}
\text { offsite }_{\text {MFP }}=\left(2.69 \times 10^{-6}\right) & \left(1.48 \times 10^{-5}\right)\left(3.3 \times 10^{-4}\right)\left(2.1 \times 10^{5}\right) \\
= & 2.76 \times 10^{-9} \mathrm{rem}
\end{aligned}
\end{aligned}
$$

60. Page 3-30, Equations (32) and (34) - The correct $X / Q$ value is $1.48 E-5$, not $1.46 \mathrm{E}-5$. This changes the answers to 0.085 and $4.0 \mathrm{E}-6 \mathrm{rem}$ respectively, here and on Page 1-3. Comment accepted and text changed as requested. 
61. Page 3-33, Table 3-20 - Where are the $X / Q$ values listed? Make this section parallel the radiological analyses. Comment accepted. The following text and calculations involving the product of the source term of Section 3.1 .4 .5 .2 and the onsite and offsite $x / 0$ values will be attached to bottom of the first paragraph of Section 3.1.4.5.3, right before Table 3-19. These calculations derive the values in Table 3-19, whose values are in turn used in Table 3-20 to determine Phosgene concentrations.

The concentrations are shown in Table 3-19 and are derived in the following calculations.

Onsite Carbon Tetrachloride Concentration

$$
9.91 \times 10^{4} \mathrm{mg} / \mathrm{s} \times 3.14 \times 10^{-5} \mathrm{~s} / \mathrm{m}^{3}=3.1 \mathrm{mg} / \mathrm{m}^{3}
$$

Offsite Carbon Tetrachloride Concentration

$$
9.91 \times 10^{4} \mathrm{mg} / \mathrm{s} \times 3.75 \times 10^{-6} \mathrm{~s} / \mathrm{m}^{3}=0.37 \mathrm{mg} / \mathrm{m}^{3}
$$

Why is there no corresponding truck accident for the radiological implications? Put it back in. Comment noted and discussed. The truck accident scenario is external to the facility and was previously dropped.

62. Page 3-33, Paragraph 1, Line 2 - There is now no Section 3.1.3.4.4, and no basis for the truck frequency accidents. (See preceding comment.) Comment accepted and the following additional paragraph added which develops the frequency for the truck accident scenario:

"A del ivery truck must lose control and crash, the severity of the crash must be sufficient to breach the fuel tank, and the fuel must ignite in order for the truck fire scenario to occur. The truck could lose control because of an equipment failure (e.g., brakes, steering), or an operator error. An operator error is assumed for this analysis and a frequency of $1 \times 10^{-3} /$ delivery is applied. Fires occur in 0.4 percent of accidents in which a truck collides with a fixed object (Clarke 1976). Order of magnitude reduction is applied to account for the slow speeds within the fenced area surrounding the 224-T Building relative to highway/freeway speeds. This yields a probability of $4 \times 10^{-4}$. The frequency of a truck accident resulting in a fire is therefore $4 \times 10^{-7} /$ delivery. The TRUSAF receives $\approx 24$ TRU waste shipments per year, based on past operating history. However, fifty deliveries per year is assumed. The frequency of truck fire is therefore: 


$$
\text { Frequency }_{\text {truck fire }}=\left(\frac{4 \times 10^{-7}}{\text { delivery }}\right) \times\left(\frac{50 \text { deliveries }}{\text { year }}\right)=2.0 \times 10^{-5} / \text { year } \text {. }
$$

63. Page 3-37, Paragraph 3, Line 16 - Add "for purposes of hazard classification in this section of this document" between "used" and "for". Comment accepted and text changed as requested.

64. Page 3-37, Paragraph 4, Line 4 - Add "deflagration" between "drum" and "accident". Comment accepted and text changed as requested. Deleted "in section 3.1.4.4" in Line 5 also.

65. Page 3-39, Paragraph 1, Line 2 - Change "3.1.4.4.3" to "3.1.4.3.2". Comment accepted and text changed as requested.

66. Page 3-39, Paragraph 3, Line 6 - Add "and dispositioned appropriately". to the end of this sentence after "material". Comment accepted and text changed as requested.

67. Page 3-40, Paragraph 1, Line 1 - What is meant by "extremely conservative"? Is it possible to have a single drum with $100 \%$ combustible contents? Change "an extremely" to "a". The contrast between $84 \%$ and $65 \%$ seems to be over-emphasized. Comment accepted and text changed as requested.

68. Page 3-40, Paragraph 3, Line 6 - Why isn't the ventilation system considered to be "safety significant"? Comment noted, however the ventilation system does not meet the criteria necessary to be safety significant.

69. Page 3-43, Section 3.3, Line 5 - The risks of operations at the LLBG were accepted by RL in the LLBG ISB, not the risk acceptance guidelines. Change this sentence to state that the risks were within the riskacceptance guidelines for which risks at the SWBG were found to be acceptable. Comment accepted and text changed as requested.

70. Page 4-1, Paragraph 2 Last sentence - Add "and safety analysis" between "design" and "requirements" in Line 5, and change "the facility design" to "these" in Line 6 . Comment accepted and text changed as requested.

71. Page A-3, First bullet - Add "postulated" between "the" and "maximum". Comment accepted and text changed as requested.

72. Page A-3, Paragraph 3, Line 3 - Delete "SWITS Software Design Descriptions, WHC-SD-WM-SWD-009, Rev. 8" and the [] around "WHC 1995". Comment accepted and text changed as requested. 
73. Page $A-4$, Table A-1 - Reconcile the zero in the $>200$ gram row with Page 2-9, which states one drum was assayed at $234 \mathrm{~g}$. Are the records changed to incorporate the assay results, or are the assay results simply additional information on the possible contents? Add the dates for which the data in this table was current. Is 1105 the current total number of drums in TRUSAF? Comment accepted. The results of Table A-1 are developed in Boothe 1993 and do not represent the number of drums at TRUSAF. As described in Boothe 1993, the $\mathrm{g}$ Pu depicted in this table are taken from the waste generator certified records. This reference will be added to the bottom of the table for clarity.

74. Page A-4, Table A-2 - Use consistent nomenclature for this table and the text. The first bullet on page A-3, as well as the text of the safety analysis calls the "maximum drum" contents $400 \mathrm{~g}$, not the $194.0 \mathrm{~g}$ shown here. Comment accepted and the word "postulated" added between "the" and "maximum" in the first bullet. "Boothe 1993" added below Table A-2 to clarify source of data provided.

75. Page B-4, Table B-2 - Change " $12 \%$ plutonium" in the last row to " $12 \%$ ${ }^{240} \mathrm{Pu}^{\prime}$. Comment accepted and text changed as requested.

76. Page B-4, Paragraph 3, Line 13 - Add an explanation of why the inventory is presented in such unconventional units, and add the thought of "dose potential" to clarify what is meant by inventory in rem. Change "rems" to "rem". Comment accepted and the following added to the last sentence of paragraph 3: ", which represent a dose potential and not a dose prediction."

77. Page B-5, Table B-3 - Change the title of this table to reflect the "dose potential " thought from the preceding comment. Comment accepted and table title changed as requested.

78. Page B-5, Paragraph 1, Line 4 - Delete ", unavoidable, ". Comment accepted and text changed as requested.

79. Page B-5, Paragraph 3, Line 4 - Note that the inventories in the following equations are not given in "rems", but " $\mathrm{C}$ ". Change this sentence to "The inventory is respirable material given in curies". Explain why the inventory values used are not consistent with those given in Appendix D. Comment accepted and text changed as requested. Additionally the following changes are made to Appendix B for clarity:

1) The first paragraph on page B-5 is moved to page B-4 following Table $B-2$ to complete the development of the elements necessary to calculate the dose as defined by equation B-1.

2) The second sentence of paragraph 2 on page $B-5$ will be changed to: "The radiological characterization information of Appendix $A$ is used as a sample to make the following sample calculations."

3) The following will be added to the end of the first sentence of paragraph 3 on page B-5: ", taken from the average drum distribution depicted in Appendix A. See Table A-2." 
80. Page $C-3$, Paragraph 1, Line 3 - Delete "SWITS Software Design Descriptions, WHC-SD-WM-SWD-009, Rev. 8" and the [] around "WHC 1995". Comment accepted and text changed as requested.

81. Page $C-3$, Paragraph 1, Line 7 - Explain the mathematical basis for this sentence. It does not make sense to me. The volume percents times the density times the drum volume has to be the drum total weight (unless the weight of the steel in the drum itself was considered in the density and not given an appropriate volume percentage for the calculation). Comment accepted. Sentence will be clarified by changing the word "weight" to "drum waste total weight". As indicated the values calculated exceeded the actual drum waste total weights, hence a \% void was calculated by relating the calculated weight to the actual measured weights.

82. Page C-3, Paragraph 1, Line 10 - Reconcile the $83 \%$ void volume with WHCEP-0063's prohibition on $>10 \%$ voids. What is meant by $83 \%$ void volume? I doubt the drums are only $17 \%$ full. Is this intended to mean that the actual density is only $17 \%$ of the theoretical maximum density? In any case, the mathematical basis of this sentence is flawed. (See preceding comment.) Comment noted. Void volume as presented here talks to the amount of theoretical void inside a drum based on the densities of combustible material stored therein. There is currently no prohibition on $>10 \%$ voids for temporary storage of TRU drums.

83. Page D-3, Paragraph 2, Line 6 - Why is this reference to Appendix $B$ here? Delete it. Comment accepted and text changed as requested.

Comments on IOSR:

1. Page 5-2, Item $d$. - Add "5.2.1, "between "specified in" and "5.3.1" in both paragraphs of this item. Change "attempted to implement" to "implemented" in the first paragraph. Comment accepted and text changed as requested.

2. Page 5-7, Section 5.4.1 - Add an additional specific item as follows: "95 percentile drum contents not to exceed $150 \mathrm{~g} \mathrm{Pu}$." Comment noted, no text change is necessary here as text in the ISB will be revised. The forklift accident has been revised to involve two $400 \mathrm{q}$ Pu drums to be consistent with the rest of the accident analysis.

Rudy Guercia Comments:

1. Page 1-1, Paragraph 2, Line 2 - Change "Corp" to "Corps". Comment accepted and text changed as requested.

2. Page 2-1, Paragraph 1 - Clarify the portions of the facility covered by this ISB. Specifically state that it does not cover any operations in the sealed cells. Comment accepted and the following sentence added to paragraph 1 before the last sentence: "While all of the TRUSAF assay and storage activities are included with the cells as is, any activity to enter the cells is beyond the scope of this analysis". 
3. Page 2-1, Paragraph 4 - Add a statement to this paragraph that the accident analysis is designed to bound the potential consequences from the inventory in the sealed cells, but not any operations there. (See preceding comment.) Also explain what is going to happen to the cell doors. Are they going to be sealed? How is cell ventilation air to be supplied? Comment accepted and the following sentence added following sentence 2: "The accident analysis is designed to bound the potential consequences from the inventory in the sealed cells, but not any operation there". The cell doors remain unseal as described in the text and provide leakage air to the process cell.

4. Page 2-7, Paragraph 7 - Note that WHC-EP-0063 does provide for a waiver to the $200 \mathrm{~g}$ limit, and that this ISB supports individual drum contents up to $400 \mathrm{~g}$, as long as the 95 percentile average drum content does not exceed $150 \mathrm{~g}$. Comment accepted and the following sentence added following the 5 th sentence: "Based on the criticality limit of $400 \mathrm{~g}$ fissile material and the analysis in this safety analysis, a waiver as provided in WHC-EP-0063 can be used to allow individual drums up to $400 \mathrm{~g}$ fissile material to be stored".

5. Page 2-13, Section 2.7 - Add a description of the verification activities performed per WHC-IP-1159, and indicate how they are enveloped by the safety analysis. Comment accepted and text revised to add brief verification activity per comment \#25 above.

6. Page 2-15, Paragraph 4 - Note that the verification IP requires RTR for non-retrieved drums. Comment accepted and the word "retrieved" changed to "received."

7. Page 2-18 - This would be a good place to add the verification description. Comment noted. Brief verification sentence added by comment \#25 above.

Comments on ECN \#189884: FINAL TRANSURANIC STORAGE AND ASSAY FACILITY INTERIM SAFETY BASIS (from Morris Moser)

1. Last sentence on page $2-8$ is confusing and needs to be clarified. Comment noted and discussed. Sentence added to this paragraph to clarify margin of safety. See comment \#13 above.

2. Last sentence on page 2-9 references a 1989 WHC report for the most recent assay data; there should be more current data available and referenced in this ISB. Comment accepted and text revised to reflect updated number of drums assayed through July 1996.

3. Last sentence on page 2-10 needs to address how supply air is provided to process cell A which, unlike the other process cells has a sealed exterior door. Comment noted. As shown in fiqure 2-4 the upper portion of a 71 the process cells are open to each other. The supply air for process cell $A$ is supplied by infiltration from the unsealed exterior doors of the other process cells. No change will be made to the text on page 2-10. 


\section{WHC-SD-WM-ISB-004 REV 1}

4. 4th Paragraph on page 2-16, last sentence, change $10.7 \mathrm{~mm}$ to $1.07 \mathrm{~mm}$. Comment accepted and text changed as requested.

5. Table 3-7 on page 3-12, column $D$ there is a superscript ' $b$ ' shown on 'Correction factor' and it is unclear what this means. Comment accepted and "Note: "below Table 3-7 changed to "b". 


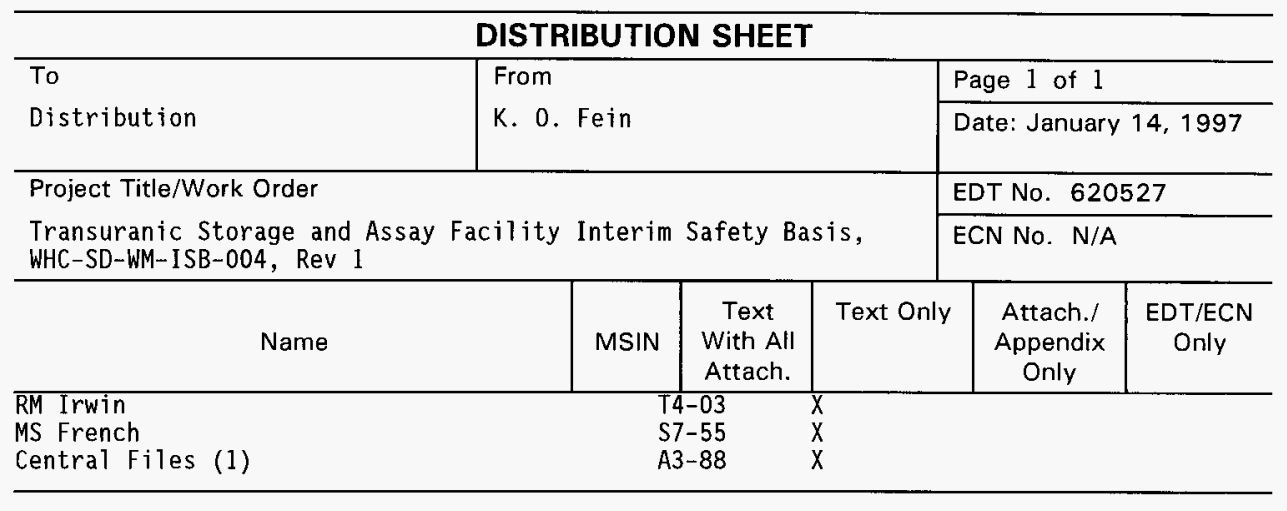

